\title{
Desenvolvimento de formulações cosméticas contendo óleos vegetais para a proteção e reparação capilar
}

\author{
Dissertação de Mestrado apresentada ao Programa \\ de Pós-Graduação em Ciências Farmacêuticas \\ para obtenção do Título de Mestre em Ciências \\ Área de Concentração: Medicamentos e \\ Cosméticos \\ Orientada: Lidiane Advíncula de Araújo \\ Orientadora: Prof. ${ }^{a}$ Dr. ${ }^{a}$ Patrícia M. B. G. Maia \\ Campos
}

Versão Corrigida da Dissertação de Mestrado apresentada ao Programa de Pós-Graduação de Ciências Farmacêuticas em 23/04/2015. A versão original encontra-se disponível na Faculdade de Ciências Farmacêuticas de Ribeirão Preto/USP.

Ribeirão Preto 
AUTORIZO A REPRODUÇÃO E DIVULGAÇÃO TOTAL OU PARCIAL DESTE TRABALHO, POR QUALQUER MEIO CONVENCIONAL OU ELETRÔNICO, PARA FINS DE ESTUDO E PESQUISA, DESDE QUE CITADA A FONTE.

Araújo, Lidiane Advíncula

Desenvolvimento de formulações cosméticas contendo óleos vegetais para a proteção e reparação capilar. Ribeirão Preto, 2015.

90 p.; $30 \mathrm{~cm}$.

Dissertação de Mestrado, apresentada à Faculdade de Ciências Farmacêuticas de Ribeirão Preto/USP - Área de concentração: Medicamentos e Cosméticos.

Orientadora: Maia Campos, Patrícia Maria Berardo Gonçalves

1. Cabelo 2. Formulações cosméticas. 3. Óleos vegetais. 4. Radiação solar 5. Alisamento Químico 


\title{
FOLHA DE APROVAÇÃO
}

Lidiane Advíncula de Araújo

Desenvolvimento de formulações cosméticas contendo óleos vegetais para a proteção e reparação capilar

Dissertação de Mestrado apresentada ao Programa de Pós-Graduação em Ciências Farmacêuticas para obtenção do Título de Mestre em Ciências

Área de Concentração:Medicamentos e Cosméticos

Orientadora: : Prof. $^{\text {a }}$ Dr. $^{\text {a }}$ Patrícia M. B. G. Maia Campos

Aprovada em:

\author{
Banca Examinadora
}

Prof. Dr.

Instituição: Assinatura:

Prof. Dr.

Instituição: Assinatura:

Prof. Dr.

Instituição: Assinatura: 


\section{Dedicatória}

Aos meus pais, Antônio e Lúcia, pelo apoio e amor de sempre, e por serem meus eternos exemplos.

Aos meus irmãos, Ludmilla e Antônio, pela presença fundamental em todas as etapas da minha vida. 


\section{Agradecimentos}

A Deus, por sempre me iluminar e dar forças para conseguir cumprir os meus objetivos.

A minha orientadora, Prof. ${ }^{a}$ Dr. ${ }^{a}$ Patrícia Maia Campos, pela oportunidade da realização do mestrado, pela orientação e por ter me ensinado muito além do que o relacionado ao meu projeto.

Ao Professor Gilberto Úbida por gentilmente ter me permitido utilizar o Simulador Solar, e ao técnico Fernando Grine, pela cordial ajuda na utilização desse equipamento.

Ao Professor Oswaldo de Freitas por ter me cedido seu laboratório para utilização do Texturômetro, e ao Hugo Favacho pela disponibilidade de sempre em me auxiliar.

Ao Professor Pedro Rocha-Filho por gentilmente me permitir utilizar o equipamento Chromameter.

Ao técnico Rodrigo Silva pela atenção e disponibilidade de sempre para a realização das análises do MEV.

À tecnica Ieda Prado, pela essencial ajuda nas análises de Fluorescência.

Às Professoras Maria José Fonseca, Maria Valéria Velasco e Juliana Marchetti pelas valiosas sugestões no meu exame de qualificação.

Ao técnico do laboratório, Luiz Fernando, pela sua colaboração.

Às pós-graduandas do NEATEC, Carla, Daiane, Lívia, Marina e Wanessa, pelos ótimos momentos de descontração e conversas sempre produtivas.

Às alunas de iniciação científica, Flávia, Marcella, Stefânia e Gabriela, presentes desde o início do desenvolvimento do meu projeto e à toda equipe NEATEC.

À Tais Wagemaker, pela inestimável ajuda e amizade, essenciais para que eu finalizasse meu projeto.

A Mariana, Jirrah, Raquel, Tulio e Flávio por toda ajuda nas etapas iniciais do desenvolvimento do meu projeto e na adaptação em Ribeirão Preto.

A Karini Costa e Natália Gonçalves pela amizade e apoio. Vou sempre me lembrar de vocês.

Aos amigos da pós-graduação. 
Às minhas amigas, Layla, Lilian, Thays, Ana Paula, Adriane, Camila, Carol e Isadora, que, como em todas as etapas da minha vida, aqui também foram essenciais.

Às minha primas, Natália, Thais e Thiela pelo apoio de sempre.

Ao meu namorado, Eduardo Barreira, pelo apoio e companherismo de sempre, fazendo com que tudo se tornasse mais leve.

A todos os familiares e amigos que, de alguma forma, participaram deste momento e torceram por mim.

Muito Obrigada! 
"A vida é assim: esquenta e esfria, aperta e daí afrouxa, sossega e depois desinquieta. $O$ que ela quer da gente é coragem"

João Guimarães Rosa 


\title{
RESUMO
}

\author{
ARAÚJO, L.A. Desenvolvimento de formulações cosméticas contendo óleos vegetais para \\ a proteção e reparação capilar. 2015. 90f. Dissertação (Mestrado). Faculdade de Ciências \\ Farmacêuticas de Ribeirão Preto - Universidade de São Paulo, Ribeirão Preto, 2015.
}

A fibra capilar está exposta a danos diários, como radiação solar, poluição, ato de pentear, higienização e fatores endógenos, além de tratamentos químicos, com o alisamento capilar. Assim, os produtos cosméticos possuem grande importância, uma vez que são desenvolvidos de forma a restaurar a fibra capilar danificada, que é mais porosa e hidrofílica, e proteger os cabelos de danos futuros. Os óleos vegetais destacam-se como importantes constituintes de produtos cosméticos, seguindo uma tendência mundial de incorporar ingredientes naturais em formulações para cuidados da pele e cabelos. Nesse contexto, o objetivo do presente trabalho foi desenvolver formulações cosméticas contendo óleos vegetais para a proteção e reparação capilar. Para tal, foram selecionados os óleos vegetais de abacate, argan e moringa, e desenvolvidas formulações contendo os óleos isolados ou associados, para aplicação em cabelos submetidos ao alisamento químico. Além disso, na etapa de pré-tratamento, foi incorporado um filtro solar às formulações. Em seguida, foi feito um direcionamento racional da escolha da formulação com maior potencial para ser utilizada nas etapas posteriores, usando a análise sensorial em mechas de cabelo e avaliação das propriedades mecânicas do fio. A formulação contendo a associação dos 3 óleos vegetais foi selecionada e, então, submetida aos estudos de estabilidade e reologia. Ao final das análises, as formulações mais adequadas à proposta do estudo foram selecionadas e aplicadas em mechas de cabelo submetidas a radiação solar, em duas etapas: pré e pós-tratamento, em relação à indução do dano. Com isso, o objetivo foi verificar se os cosméticos desenvolvidos teriam efeitos na prevenção ou recuperação dos danos causados pela radiação solar. Assim, foram avaliadas imagens obtidas por meio de Microscopia Eletrônica de Varredura, além da resistência mecânica do fio, dosagem da perda de triptofano por avaliação da intensidade de fluorescência e medidas da variação da cor da fibra capilar. Observou-se que os melhores resultados obtidos com os óleos vegetais foi na avaliação da resistência capilar, enquanto a adição do filtro solar teve impacto positivo também na redução da degradação do triptofano. Além disso, de maneira geral, os resultados indicam que o pré-tratamento foi mais eficaz em proteger a fibra capilar, quando comparado à capacidade de recuperar os danos por meio do pós-tratamento. Entretanto, o pós-tratamento foi importante para melhoria das propriedades sensoriais e para proteção de danos futuros. Com isso, dentre as formulações desenvolvidas, a que continha a associação dos óleos vegetais e do filtro solar, utilizada na etapa de prétratamento, foi a que levou aos melhores resultados, quando aplicada em mechas de cabelo.

Palavras-chave: cabelo, formulações cosméticas, óleos vegetais, radiação solar, alisamento químico. 


\begin{abstract}
ARAÚJO, L.A. Development of cosmetic formulations with vegetable oils for hair care. 2015. 90f. Dissertation (Master). Faculdade de Ciências Farmacêuticas de Ribeirão Preto Universidade de São Paulo, Ribeirão Preto, 2015.
\end{abstract}

Hair is a very important and distinctive feature that plays a major role in self perception and is part of the individual's identity. The hair fiber is exposed to daily damage, such as solar radiation, pollution and grooming, and endogenous factors, besides chemical treatments such as hair straightening. Therefore, cosmetic products are of great importance, since they are developed to restore the damaged hair fiber and to protect the hair from further damage. Vegetable oils stand out as important cosmetic ingredients, following a global trend to add natural ingredients in formulations for skin and hair care. In this context, the aim of this study was to develop cosmetic formulations containing vegetable oils for hair protection and repairing. For this purpose, three vegetable oils (avocado, argan and moringa oil) were selected for the development of cosmetic formulations for use in straightened hair. After that, the most suitable formulation was selected based on the results of sensory analysis and mechanical properties evaluation on hair tresses. The formulation containing the combination of 3 vegetable oils was selected and then evaluated in terms of stability studies and rheological behaviour. This way, the most appropriate formulations were selected and applied to strands of hair exposed to solar radiation in two different stages: pre and post-treatment in relation to the induction of the damage. Thus, the objective was to verify if the developed formulations would have effects in the prevention or repairing of solar damage hair. For this purpose, observations in Scanning Electron Microscopy, tensile properties evaluation, tryptophan degradation, and color measurements of the hair fiber were performed. Regarding the vegetable oils, the best results were found in the the tensile properties evaluation, whereas the addition of sunscreen had a positive impact on the assessment of the tensile properties evaluation and in the tryptophan degradation analysis, as well. Moreover, the results indicate that the pre-treatment was most effective than the post-treatment. Nevertheless, the posttreatment was important to improve the sensory properties. Thus, among the developed formulations, the one containing the combination of vegetable oils and the sunscreen, used in the pre-treatment, led to the best results when applied to hair tresses.

Keywords: hair, cosmetic formulation, vegetable oils, solar radiation, hair straightening 


\section{LISTA DE FIGURAS}

Figura 1. Exemplos de ligações químicas que ocorrem entre as cadeias de queratinas constituintes do fio de cabelo. .05

Figura 2. Estruturas morfológicas principais do fio de cabelo .07

Figura 3. Diferentes camadas cuticulares

Figura 4. Estrutura da camada do córtex do fio de cabelo .10

Figura 5. Descrição dos tratamentos realizados nas mechas de cabelo submetidas às análises sensoriais .36

Figura 6. Distribuição das mechas de cabelo nos grupos de tratamento. 42

Figura 7. Valores de $\mathrm{pH}$ obtidos para as 12 formulações de pré-tratamento desenvolvidas (FPE1-12), durante os 7 primeiros dias após o preparo. .54

Figura 8. Valores de $\mathrm{pH}$ obtidos para as 10 formulações de pós-tratamento desenvolvidas (FPO1-10), durante os 7 primeiros dias após o preparo . .55

Figura 9. Somatório das notas dadas pelas voluntárias para os parâmetros (1) Brilho e

(2) Sedosidade, na etapa de pré-tratamento. .57

Figura 10. Somatório das notas dadas pelas voluntárias para os parâmetros (1) Brilho e (2) Sedosidade, na etapa de pós-tratamento .57 
Figura 11. Valores de Força Máxima (gf) resisitida pelo fio de cabelo até sua ruptura na etapa de pré-tratamento com Hidróxido de Guanidina (H.G.)..........................................59

Figura 12. Valores de Força Máxima (gf) resisitida pelo fio de cabelo até sua ruptura na etapa de pré-tratamento com Tioglicolato de Amônio (T.A.)

Figura 13. Valores de Força Máxima (gf) resisitida pelo fio de cabelo até sua ruptura na etapa de pós-tratamento com Tioglicolato de Amônio (T.A.)

Figura 14. Reograma de pré-tratamento com ativos, proporção BA:AC igual a 3:3, armazenada no (A) ambiente, (B) $37^{\circ} \mathrm{C}$, (C) $45^{\circ} \mathrm{C}$ e (D) $4^{\circ} \mathrm{C}$, por um período de 28 dias

Figura 15. Reograma de pré-tratamento veículo, proporção $\mathrm{BA}: \mathrm{AC}$ igual a 3:3, armazenada no (A) ambiente, (B) $37^{\circ} \mathrm{C}$, (C) $45^{\circ} \mathrm{C}$ e (D) $4^{\circ} \mathrm{C}$, por um período de 28 dias.

Figura 16. Reograma de pós-tratamento com ativos, proporção BA:AC igual a 3:4, armazenada no (A) ambiente, (B) $37^{\circ} \mathrm{C}$, (C) $45^{\circ} \mathrm{C}$ e (D) $4^{\circ} \mathrm{C}$, por um período de 28 dias.

Figura 17. Reograma de pós-tratamento veículo, proporção BA:AC igual a 3:4, armazenada no (A) ambiente, (B) $37^{\circ} \mathrm{C}$, (C) $45^{\circ} \mathrm{C}$ e (D) $4^{\circ} \mathrm{C}$, por um período de 28 dias

Figura 18. Valores de Força Máxima (N) obtidos para as mechas de cabelo, submetidas ou não ao tratamento com as formulações cosméticas desenvolvidas, antes e após exposição ao Simulador Solar.

Figura 19. Micrografia Eletrônica de Varredura do fio de cabelo virgem em um aumento de 1.000 vezes (A) e 5.000 vezes (B), com detalhes da cutícula com camadas sobrepostas em um cabelo saudável.

Figura 20. Micrografia Eletrônica de Varredura do fio de cabelo após exposição a um simulador solar por $144 \mathrm{~h}$. Aumento de 1.000 vezes (A) e 5.000 vezes (B, C e D), com detalhes da cutícula com células fragmentadas e exposição do córtex.

Figura 21. Micrografia Eletrônica de Varredura do fio de cabelo submetido ao pré tratamento com formulação veículo em um aumento de 1.000 vezes (A) e 5.000 vezes (B), com detalhes da cutícula preservada, com células sobrepostas 
Figura 22. Micrografia Eletrônica de Varredura do fio de cabelo submetido ao pré tratamento com formulação veículo adicionada de filtro solar em um aumento de 1.000 vezes (A) e 5.000 vezes (B), com detalhes da cutícula preservada, com células sobrepostas.

Figura 23. Micrografia Eletrônica de Varredura do fio de cabelo submetido ao pré tratamento com formulação veículo adicionada dos óleos vegetais em um aumento de 1.000 vezes (A) e 5.000 vezes (B), com detalhes da cutícula preservada, com células sobrepostas. .77

Figura 24. Micrografia Eletrônica de Varredura do fio de cabelo submetido ao pré tratamento com formulação veículo adicionada de filtro solar e óleos vegetais em um aumento de 1.000 vezes (A) e 5.000 vezes (B), com detalhes da cutícula preservada, com células sobrepostas.

Figura 25. Micrografia Eletrônica de Varredura do fio de cabelo submetido ao póstratamento com formulação veículo em um aumento de 1.000 vezes (A) e 5.000 vezes (B), com detalhes da cutícula com regiões danificadas, com células fragmentadas e exposição do córtex . .77

Figura 26. Micrografia Eletrônica de Varredura do fio de cabelo submetido ao póstratamento com formulação veículo adicionada de filtro solar e óleos vegetais em um aumento de 1.000 vezes (A) e 5.000 vezes (B), com detalhes da cutícula preservada, com células sobrepostas

Figura 27. Intensidade de Fluorescência (u.a.) obtidos para as mechas de cabelo submetidas a diferentes tratamentos com formulações cosméticas, antes ou após exposição no Simulador Solar, e seus respectivos controles (Cabelo virgem e cabelo irradiado sem nenhum tratamento cosmético). 


\section{LISTA DE TABELAS}

Tabela 1 - Descrição das camadas da cutícula e seus respectivos conteúdos percentuais de cistina.

Tabela 2 - Composição de ácido graxos (\%) em diferentes óleos vegetais.

Tabela 3 - Composição das formulações de pré-tratamento contendo óleo de argan, abacate e moringa desenvolvidas na etapa inicial.

Tabela 4 - Composição das formulações de pré-tratamento contendo óleo de argan, abacate e moringa desenvolvidadas na etapa inicial.

Tabela 5 - Composição das formulações de pré-tratamento e pós tratamento, contendo óleo de argan, abacate e moringa da segunda etapa de desenvolvimento.

Tabela 6 - Valores de DL*, $\mathrm{Da}^{*}$ e $\mathrm{Db}^{*}$ obtidos para as mechas de cabelo empregando o equipamento Skin Colorimeter ${ }^{\circledR}$

Tabela 7 - Valores de DL*, Da* e Db* obtidos para as mechas de cabelo empregando o equipamento Chromameter ${ }^{\circledR}$. 


\section{LISTA DE ABREVIATURAS E SIGLAS}

18-MEA

ABIHPEC

ANVISA

CI

CIE

$\mathrm{CMC}$

CV

FAPESP

FCFRP

FPE

FPO

HG

KAP

TA

VPE

VPEF

VPEO

VPEOF

VPO

VPOO

USP

UV
Ácido 18-metileicosanoico

Associação Brasileira da Indústria de Higiene Pesosal, Perfumaria e Cosméticos

Agência Nacional de Vigilância Sanitária

Cabelo Irradiado

Comissão Internacional de Iluminação

Complexo da Membrana Celular

Cabelo Virgem

Fundação de Amparo à Pesquisa do Estado de São Paulo

Faculdade de Ciências Farmacêuticas de Ribeirão Preto

Formulação de Pré-tratamento

Formulação de Pós-tratamento

Hidróxido de Guanidina

Proteínas Associadas de Queratina

Tioglicolato de Amônio

Veículo de Pré-tratamento

Veículo de Pré-tratamento adicinado de filtro solar

Veículo de Pré-tratamento adicinado dos óleos vegetais

Veículo de Pré-tratamento adicinado dos óleos vegetais e filtro solar

Veiculo de Pós-tratamento

Veiculo de Pós-tratamento adiconado dos óleos vegetais

Universidade de São Paulo

Ultravioleta 


\section{SUMÁRIO}

Resumo

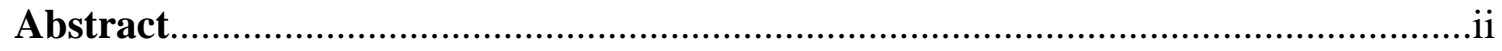

Lista de Figuras............................................................................................ii

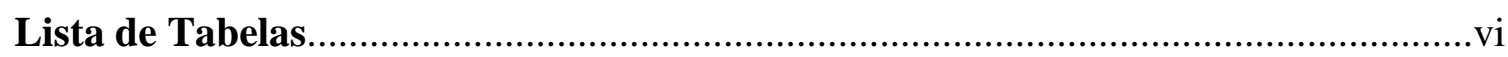

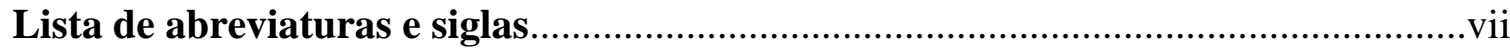

1 Introdução

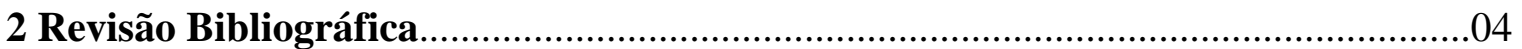

2.1 Estrutura da fibra capilar.....................................................................................

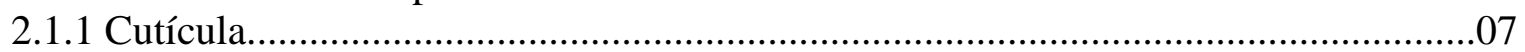

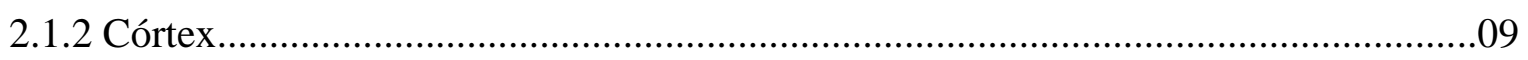

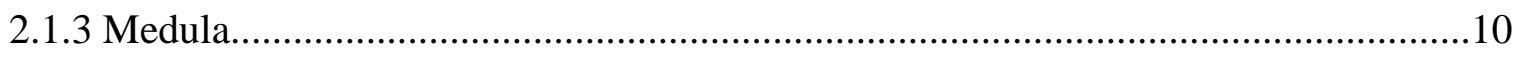

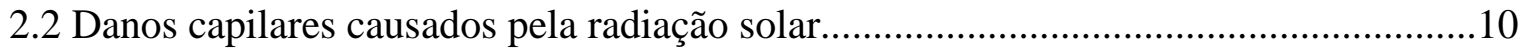

2.3 Danos capilares causados por alisamentos químicos ................................................12

2.4 Óleos vegetais e sua aplicação em cosméticos capilares...............................................15

2.5 Desenvolvimento de formulações cosméticas capilares................................................19

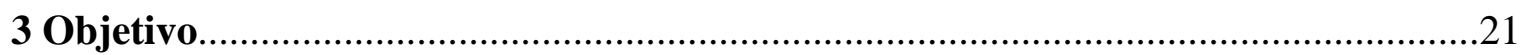

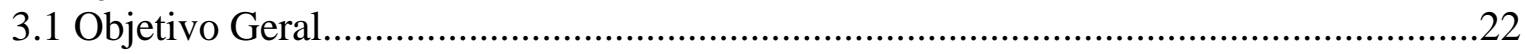

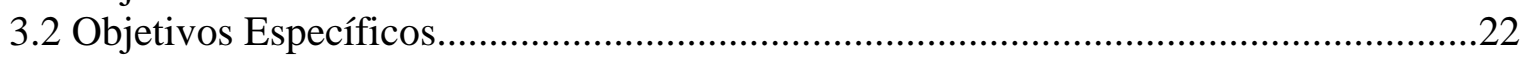

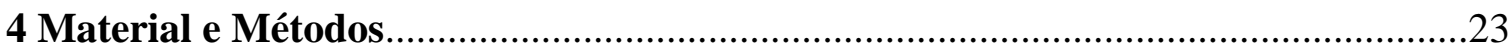

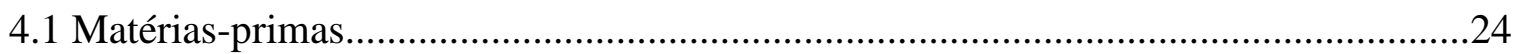

4.2 Equipamentos e Acessórios..............................................................................25

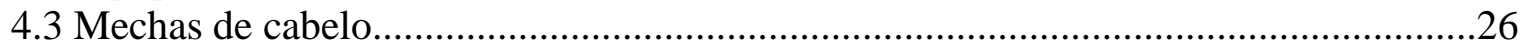

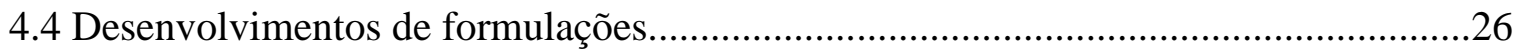

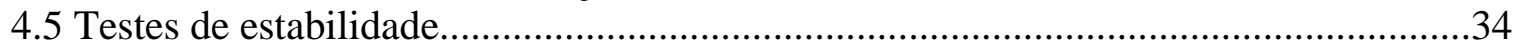

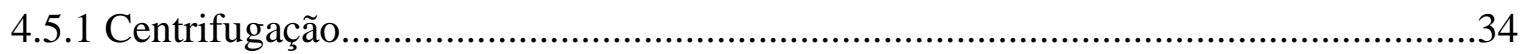

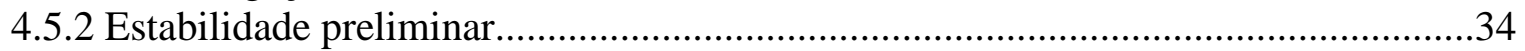

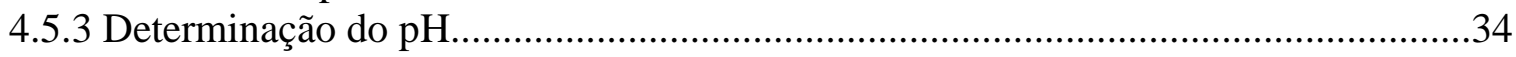

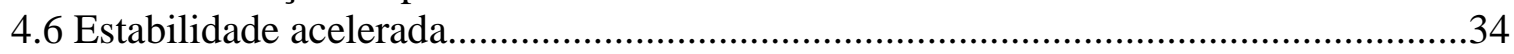

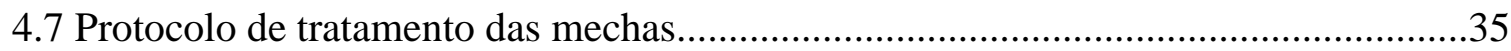

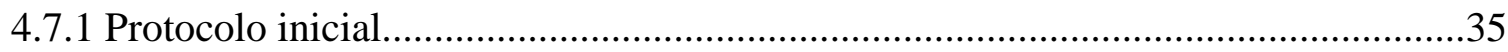

4.7.2 Aplicação das substâncias alisantes......................................................................35

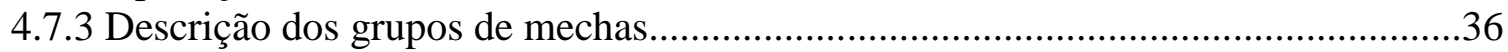

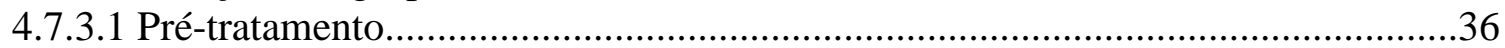

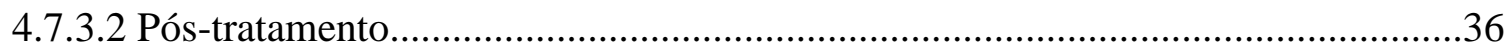

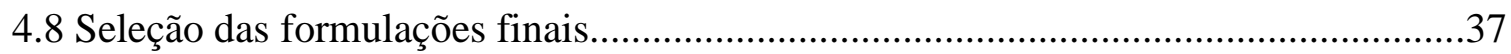




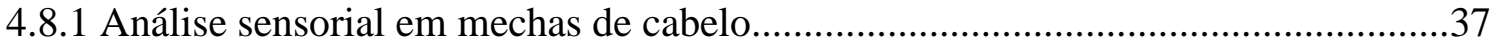

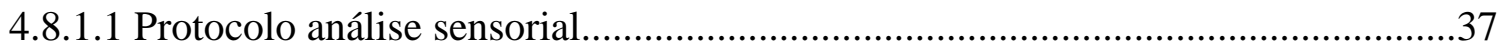

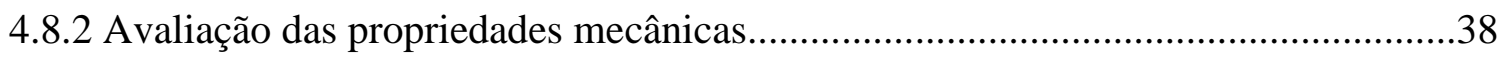

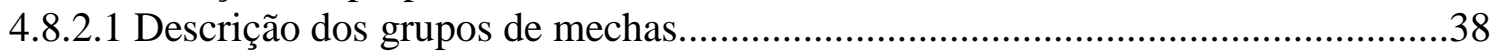

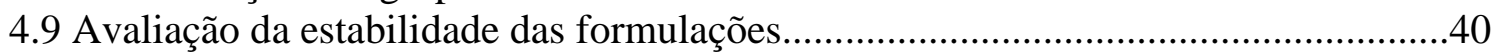

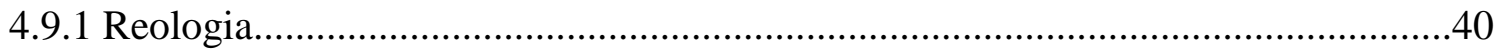

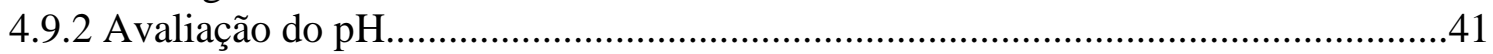

4.10 Avaliação das mechas de cabelo expostas à radiação solar.......................................41

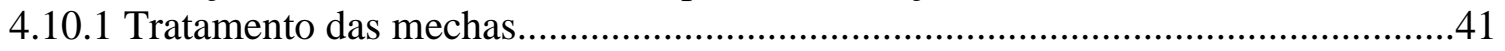

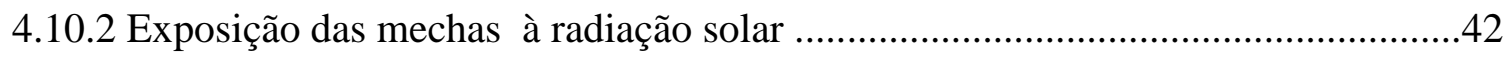

4.10.3 Avaliação das propriedades mecânicas da fibra capilar.........................................43

4.10.4 Avaliação da variação de cor das mechas de cabelo ............................................44

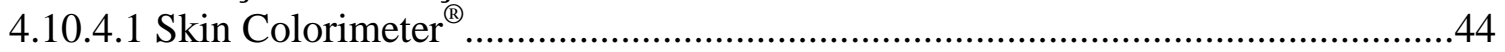

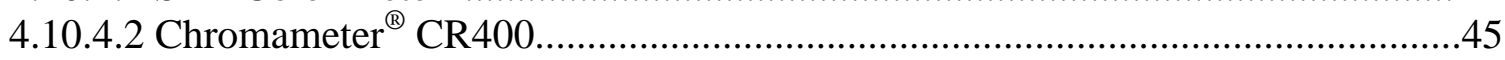

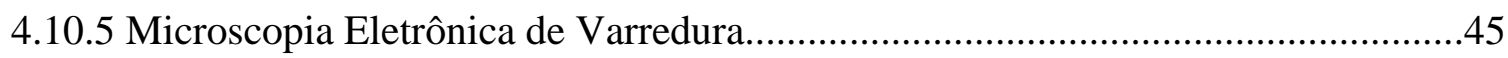

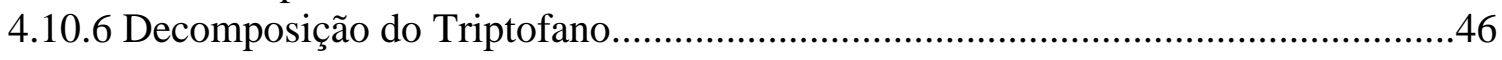

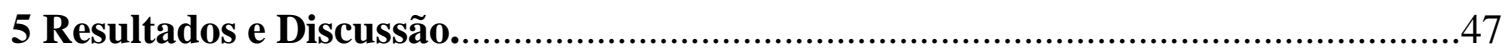

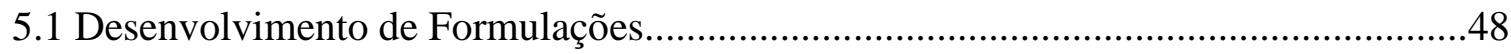

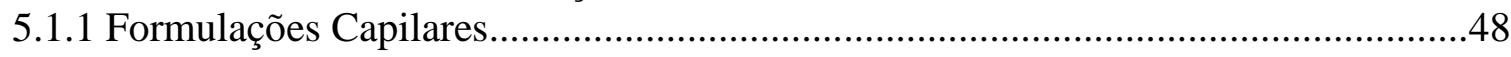

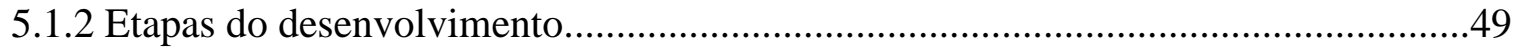

5.1.3 Desenvolvimento de formulações de pré-tratamento (FPE) ...................................52

5.1.4 Desenvolvimento de formulações de pós-tratamento (FPO)....................................53

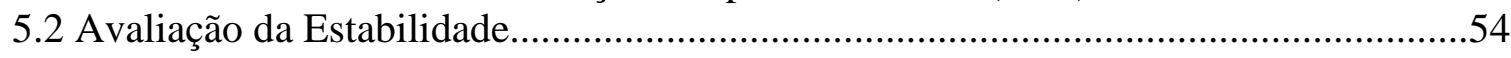

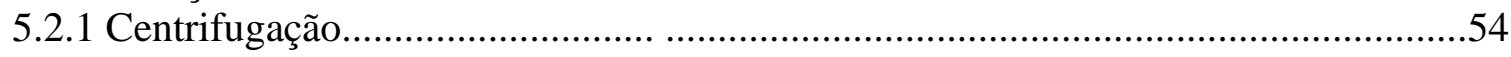

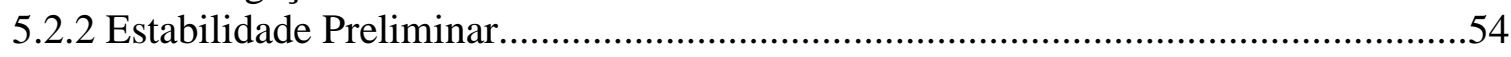

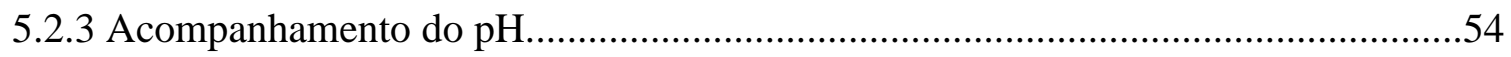

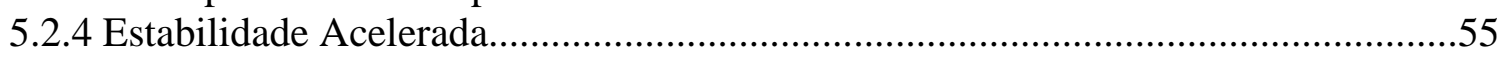

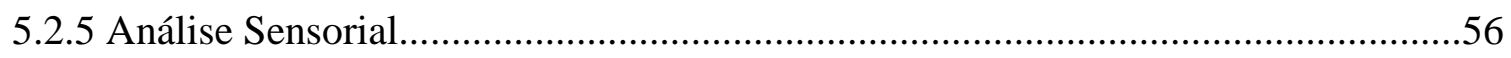

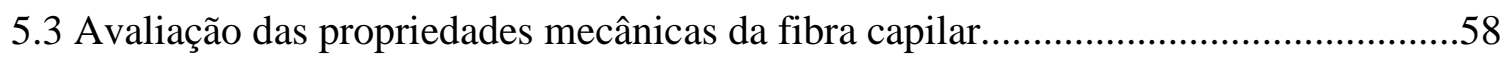

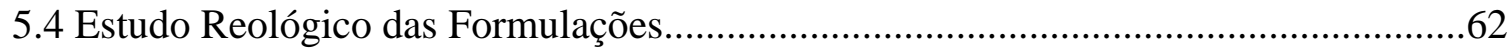

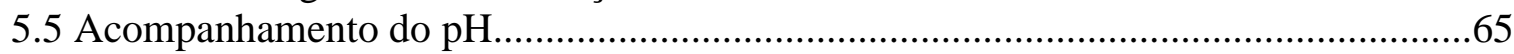

5.6 Avaliação das mechas de cabelo expostas à radiação solar..........................................65

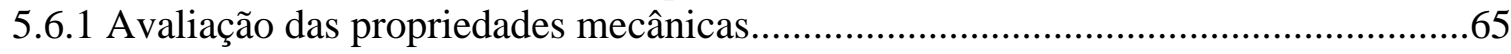

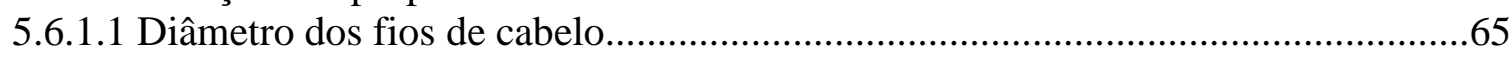

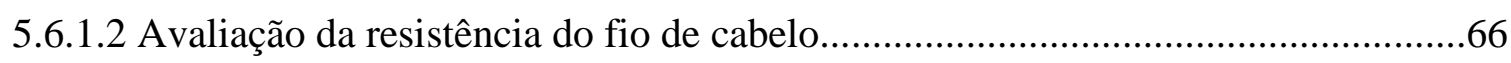

5.6.2 Avaliação da variação de cor das mechas de cabelo..............................................69

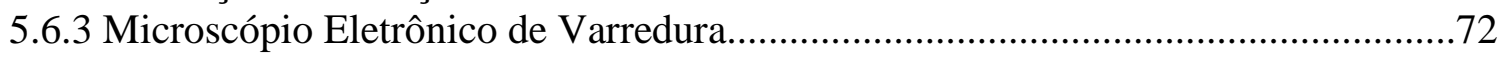

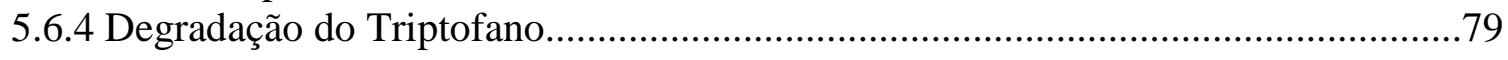

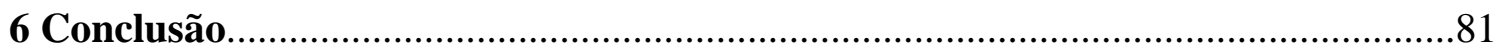

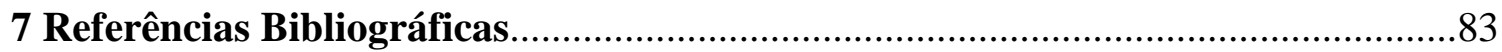




\section{Introdução}


O Brasil ocupa o terceiro mercado mundial em consumo de produtos de higiene, cosméticos e perfumaria. Nesse cenário, cosméticos capilares ocupam posição de destaque, sendo considerado o segundo maior mercado mundial, segundo dados do Euromonitor (ABIHPEC, 2014)

O cabelo é um componente marcante da imagem do corpo com importância na inserção social e auto percepção, fazendo parte da identidade do indivíduo. Além disso, é uma das poucas características físicas que podem ser alteradas facilmente, em relação a características como cor, comprimento e forma (BOLDUC; SHAPIRO, 2001).

A fibra capilar está exposta a danos diários, como radiação solar, poluição, ato de pentear, higienização e fatores endógenos. Além disso, os tratamentos químicos também são responsáveis por significativas alterações da estrutura capilar, diminuindo a resistência do fio à quebra e impactando na sensação ao toque e brilho. Sendo assim, práticas como alisamento químico danificam a fibra capilar levando a perda significativa de aminoácidos essenciais. Outro dano inerente aos processamentos químicos da fibra capilar é a remoção de uma camada de ácidos graxos que, em cabelos saudáveis, encontra-se ligada covalentemente a cutícula. Com isso, o fio torna-se mais susceptível à eletricidade estática e frizz induzido pela umidade, além de perder importantes atributos sensoriais, como sedosidade e brilho (BOLDUC; SHAPIRO, 2001; KHUMALO et al., 2010; MIRANDA-VILELA; BOTELHO; MUEHLMANN, 2014).

Apesar dos diversos danos associados aos alisamentos químicos, a realização desses procedimentos é crescente no país, principalmente devido a predominância dos cabelos crespos e ondulados.

Além disso, a radiação solar também danifica significativamente a fibra capilar, tornado-a mais frágil, com prejuízo de suas propriedades sensoriais e alterações na cor. Esse dano possui grande relevância no Brasil, devido ao clima característico da maior parte do país, com alta incidência de radiação solar em grande parte do ano.

Por tudo isso, destaca-se a importância dos cosméticos, uma vez que são desenvolvidos de forma a restaurar a maleabilidade do cabelo, diminuir a eletricidade estática, reduzir a fricção entre os fios e recondicionar a fibra danificada, que é mais porosa e hidrofílica (BOLDUC; SHAPIRO, 2001). Dessa forma, atuam tanto na prevenção, quanto na reparação de danos.

Nesse contexto, os óleos vegetais destacam-se como importantes constituintes de produtos cosméticos, seguindo uma tendência mundial de incorporar ingredientes naturais nessas formulações (KLEIMAN; ASHLEY; BROWN, 2008; VERMAAK et al., 2011). Os 
óleos vegetais tem sido utilizados há anos como fonte de energia, alimento, uso medicinal e pra aplicações cosméticas (ZIMBA; WREN; STUCKI, 2005). Possuem a capacidade de revestir a superfície dos fios e tem importante papel na melhora das propriedades sensoriais e manutenção da camada cuticular, que possui como uma das principais funções a proteção da região do córtex capilar (GUILLAUME; CHARROUF, 2011a, 2011b; RELE; MOHILE, 1999, 2003).

Para este trabalho foram selecionados os óleos de abacate, argan e moringa, devido a composição rica em ácidos graxos e grande capacidade emoliente desses óleos. O emprego dos óleos acima mencionados, isolados ou em associação, em formulações para os cuidados dos cabelos, resultou em um produto com potencial para prevenção e tratamento da fibra capilar danificada por tratamentos químicos e também pela radiação solar.

Finalmente, cabe ressaltar a importância do desenvolvimento racional de formulações cosméticas para os cabelos, de forma a assegurar que cumpram o objetivo proposto baseado não somente em dados da literatura ou no seu efeito potencial, mas também em medidas objetivas e na percepção das voluntárias, que representam os possíveis usuários do produto.

Dessa maneira, as formulações foram desenvolvidas e avaliadas quanto à estabilidade, sendo consideradas adequadas para os objetivos propostos neste estudo. 


\section{Revisão Bibliográfica}




\subsection{Estrutura da fibra capilar}

O cabelo é uma fibra com diâmetro de 50-100 $\mu \mathrm{m}$, composta por células mortas, principalmente preenchidas por queratina. Os folículos capilares estão invaginados no couro cabeludo e são as estruturas essenciais de crescimento do cabelo. Na base de cada folículo, as células se proliferam e um complexo processo de síntese de proteínas, alinhamento estrutural e queratinização, transformam o citoplasma em um material fibroso, conhecido como cabelo (BHUSHAN, 2008; WOLFRAM, 2003). O desenvolvimento do fio de cabelo é um processo cíclico dinâmico que depende não só do local do seu crescimento, mas também de aspectos como idade, hábitos nutricionais e fatores hormonais (WOLFRAM, 2003).

O cabelo humano consiste de aproximadamente $65-95 \%$ de queratina, sendo que os demais constituintes são água, lipídeos (estruturais e livres), pigmentos e elementos-traço (BHUSHAN, 2008; BOLDUC; SHAPIRO, 2001; ROBBINS, 2012; WOLFRAM, 2003). As queratinas são um grupo de mais de 30 proteínas do citosqueleto, que possuem diâmetro entre 7 e $11 \mathrm{~nm}$, sendo chamadas de filamentos intermediários. São polímeros de alto peso molecular formados por longas cadeias de aminoácidos ligados por diferentes tipos de interações, como ligações dissulfeto, ligações de hidrogênio, interações de van der Walls e ligações salinas (BHUSHAN, 2008; ERIK et al., 2008; ROBBINS, 2012; SWIFT, 1999; WOLFRAM, 2003), conforme apresentado na Figura 1.

Figura 1 - Exemplos de ligações químicas que ocorrem entre as cadeias de queratinas constituintes do fio de cabelo

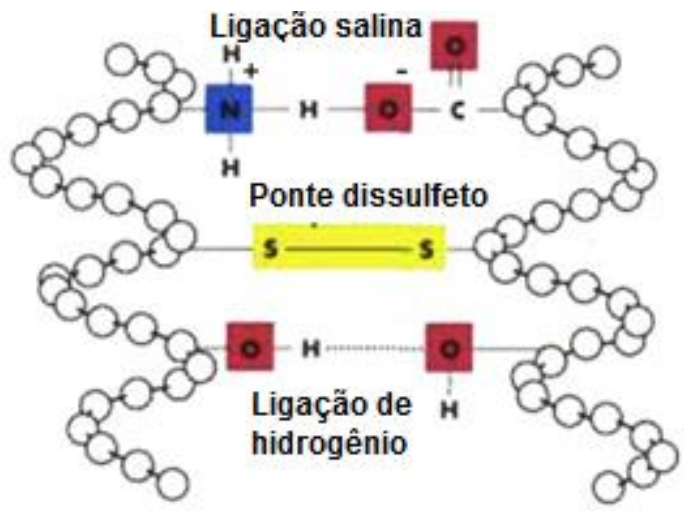

Fonte: Adaptado de Bhushan, 2008.

Embora as ligações de hidrogênio sejam relativamente fracas e prontamente desfeitas em presença de água, são as mais numerosas e possuem grande importância na manutenção da estabilidade da estrutura de $\alpha$-hélice da queratina. Essa interação ocorre entre grupos amido ao 
longo das cadeias polipeptídicas. Além disso, o grande número de cadeias laterais de aminoácidos possibilitam interações que são relativamente estáveis em ambiente aquoso, mas prontamente desfeitas em contato com ácidos ou bases. Apesar da grande contribuição das interações mencionadas, as ligações dissulfeto na cistina são as principais responsáveis pela estabilidade da estrutura da queratina (WOLFRAM, 2003).

Dentre os numerosos aminoácidos presentes na estrutura capilar, a cistina é um dos mais importantes, estando presente em grande proporção. Cada unidade de cistina é formada a partir da ligação entre os átomos de enxofre de duas cisteínas, presentes em diferentes porções das cadeias polipeptídicas. Essa ligação, denominada ligação dissulfeto, dissulfídica ou ponte de dissulfeto, é do tipo covalente e muito importante na determinação das propriedades físicas e mecânicas da fibra capilar (MIRANDA-VILELA; BOTELHO; MUEHLMANN, 2014). Essa alta incidência de ligações cruzadas entre resíduos adjacentes de cisteínas, juntamente com a susceptibilidade de ocorrência de reações de redução ou oxidação dessas ligações, caracterizam o principal alvo de ação da maioria das modificações químicas na estrutura capilar, que resultam na alteração de suas propriedades físico-químicas. (MIRANDAVILELA; BOTELHO; MUEHLMANN, 2014).

As fibras capilares não são contínuas em seu comprimento, uma vez que são resultado da combinação de grupos compactos de células dentro do folículo piloso, que resultam em três componentes morfológicos básicos: cutícula, córtex e medula (BHUSHAN, 2008; BOLDUC; SHAPIRO, 2001; MIRANDA-VILELA; BOTELHO; MUEHLMANN, 2014; ROBBINS, 2012; ROGERS, 2004; WOLFRAM, 2003). Apesar dessa divisão em três componentes, a fibra capilar é altamente organizada e de composição complexa (Figura 2). 
Figura 2- Estruturas morfológicas principais do fio de cabelo

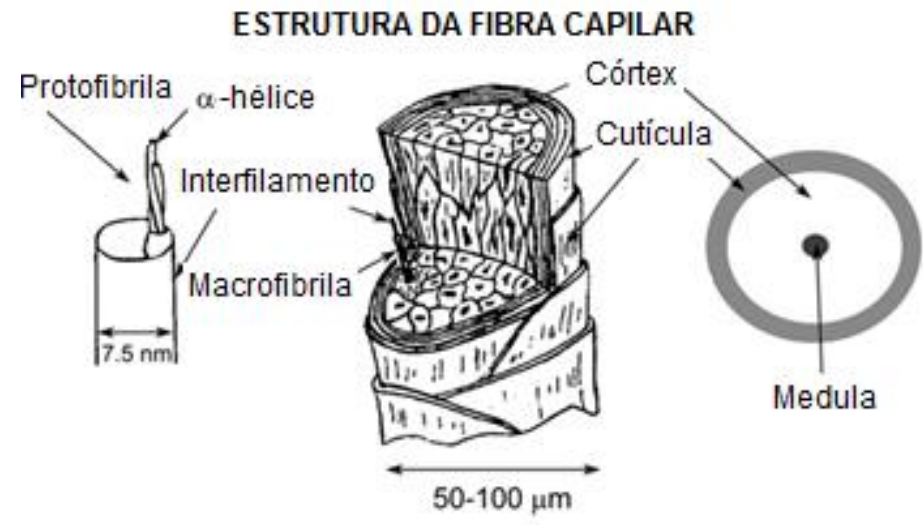

Fonte: Adaptado de Bhushan, 2008.

\subsubsection{Cutícula}

A cutícula é a região mais externa do fio de cabelo, sendo composta primariamente de queratina com uma estrutura com 5-10 células que se sobrepõem na região longitudinal da fibra, de forma que apenas 1/6 de sua superfície seja visível (BHUSHAN, 2008; BOLDUC; SHAPIRO, 2001; MIRANDA-VILELA; BOTELHO; MUEHLMANN, 2014). As células cuticulares são achatadas e com $0,5 \mu \mathrm{m}$ de espessura e $50 \mu \mathrm{m}$ de comprimento. No processo de maturação e queratinização, uma estrutura estratificada se desenvolve dentro de cada célula da cutícula. Com isso, existem diferentes camadas com composições distintas em relação ao conteúdo de cistina, conforme descrito na Tabela 1, (ROBBINS, 2012; WOLFRAM, 2003).

Tabela 1 - Descrição das camadas da cutícula e seus respectivos conteúdos percentuais de cistina.

\section{Camada da Cutícula}

Epicutícula

Camada A

Exocutícula

Endocutícula

Complexo da Membrana Celular

\section{Conteúdo de cistina (\%)}

$$
\sim 30
$$

$$
\sim 3
$$

$\sim 2$

Fonte: Adaptado de Bhushan, 2008. 
Cada célula cuticular é circundada pelo complexo da membrana celular (CMC) e, assim, separada das células vizinhas. Esse complexo consiste em um núcleo central composto por polissacarídeos e também uma pequena porção proteica (camada $\delta$ ) entre duas camadas lipídicas (camadas $\beta$ ) (WOLFRAM; LINDERMANN, 1971; WOLFRAM, 2003). A camada externa das células cuticulares é revestida por uma fina membrana denominada epicutícula, que também é recoberta por uma camada de ácidos graxos covalentemente ligados, com predominância do Ácido 18-metileicosanóico (18-MEA), que corresponde à camada $\beta$ externa do CMC (Figura 3). Sendo assim, essa camada age como um lubrificante, diminuindo a fricção entre as fibras capilares e provê uma superfície hidrofóbica (BHUSHAN, 2008; WEI; BHUSHAN; TORGERSON, 2005). Imediatamente abaixo da epicutícula, encontra-se a camada A, com aproximadamente $110 \mathrm{~nm}$ de espessura (ROBBINS, 2012). A camada A possui alta concentração de cistina, aproximadamente 30\%. Dessa forma, é a camada cuticular que possui a maior densidade de ligações cruzadas, resultando em considerável resistência química e mecânica, além de baixo grau de intumescimento quando em contato com a água (BHUSHAN, 2008; ROBBINS, 2012). Imediatamente adjacente a ela, encontra-se o maior componente da cutícula, a exocutícula, com espessura de 100-300 nm e 15-20\% de conteúdo de cistina. Da mesma forma, confere resistência química e mecância devido a sua alta concentração de cistina, embora a densidade das ligações dissulfeto entre as proteínas dessa camada seja menor, quando comparada à camada A (BHUSHAN, 2008; ROBBINS, 2012; WOLFRAM, 2003). Imediatamente abaixo, situa-se a endocutícula e, de maneira distinta, possui baixo teor de cistina, em torno de 3\%, sendo rica em resíduos de aminoácidos ácidos e básicos. Essa camada possui uma característica importante como um canal facilitador da passagem de substâncias, devido a sua baixa densidade de ligações cruzadas e caráter hidrofílico, que a torna com grande potencial de intumescimento em presença de água. (BHUSHAN, 2008; MIRANDA-VILELA; BOTELHO; MUEHLMANN, 2014; ROBBINS, 2012; WOLFRAM, 2003).

Dessa maneira, como resultado das composições variadas, as camadas cuticulares reagem de maneira distinta a diferentes procedimentos químicos e também à presença de água e surfactantes (ROBBINS, 2012). A Figura 3 ilustra a localização das diferentes camadas cuticulares, descritas anteriormente. 
Figura 3- Diferentes camadas cuticulares

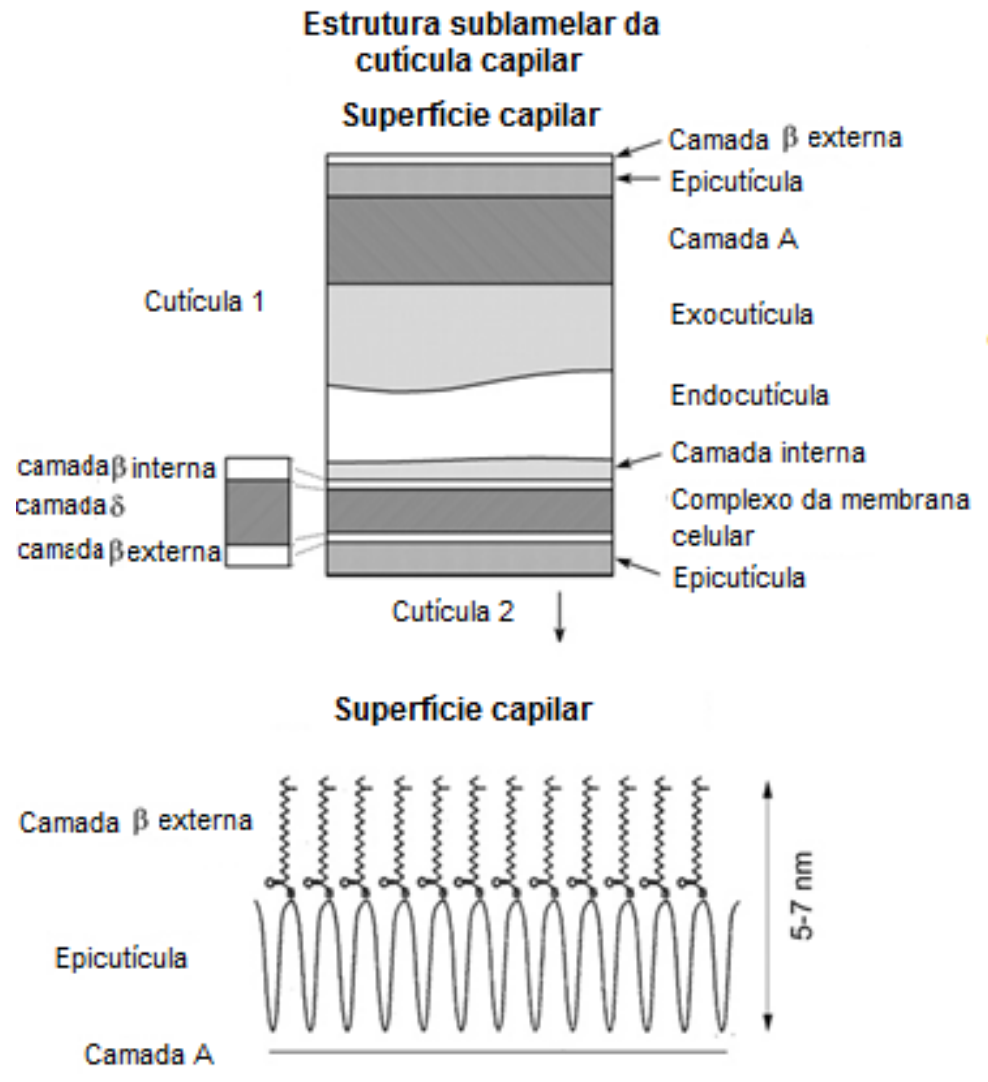

Fonte: Adaptado de Bhushan, 2008.

\subsubsection{Córtex}

Apresenta-se como o componente dominante do cabelo, sendo constituido por células alongadas, de aproximadamente $100 \mu \mathrm{m}$ de comprimento. As células encontram-se firmemente unidas e orientadas paralelamente ao eixo da fibra e embebidas em uma matriz cortical rica em cistina. Além disso, possui material de ligação intercelular, o CMC do córtex capilar. O CMC consiste de membranas celulares e material adesivo, que une as células, sendo não-queratinoso e com baixo conteúdo de cistina (2\%) (BHUSHAN, 2008; DIAS et al., 2008; ERIK et al., 2008; MIRANDA-VILELA; BOTELHO; MUEHLMANN, 2014; WOLFRAM, 2003)

O córtex possui uma estrutura hierárquica, indo da $\alpha$-hélice de queratina, que por meio de ligações químicas entre duas cadeias formam um dímero. Por sua vez, 16 desses dímeros constituem as microfibrilas (interfilamentos), e essas, juntamente com a matriz cortical, se 
rearranjam formando as macrofibrilas e as células que irão formar o fio de cabelo propriamente dito, conforme Figura 4 (CHOU; BUEHLER, 2012). Os interfilamentos possuem baixo conteúdo de cistina, aproximadamente $6 \%$, e a matriz cortical é rica em cistina, com aproximadamente $21 \%$ e é constituída por proteínas associadas de queratina (KAP).

Figura 4 -Estrutura da camada do córtex do fio de cabelo

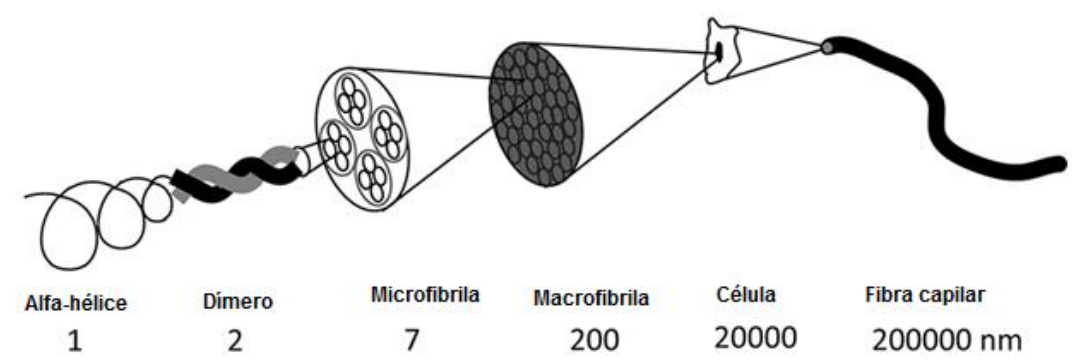

Fonte: Adaptado de Chou, 2012

Os grânulos de melanina encontram-se aleatoriamente distribuídos no córtex capilar e são responsáveis pela coloração dos cabelos. Existem dois tipos de melanina: a eumelanina , cuja cor varia do preto ao marrom, e a feomelanina, que varia do amarelo ao marrom-avermelhado, sendo que se assume que esses dois tipos originam-se de um mesmo caminho metabólico (SANTOS NOGUEIRA; JOEKES, 2004). No cabelo, as melaninas atribuem proteção fotoquímica às proteínas, ao absorver e filtrar a energia recebida, dissipando-a na forma de calor, atuando assim, como um desativador químico de radicais livres (ROBBINS, 2012; SANTOS NOGUEIRA; JOEKES, 2004)

\subsubsection{Medula}

A medula encontra-se situada no centro da estrutura capilar e não está presente em todos os fios de cabelo. Apresenta contribuição negligenciável para as propredades mecânicas do cabelo (BHUSHAN, 2008) e um menor número de estudos para avaliar sua importância e função, embora se discuta a sua influência nas propriedades óticas do fio de cabelo.

\subsection{Danos capilares causados pela radiação solar}

A degradação de proteínas do cabelo causadas pela radiação solar ocorre principalmene na região de comprimento de onda de 254-400 nm (ROBBINS, 2012). Vários 
aminoácidos do cabelo absorvem luz na faixa do ultravioleta (UV), principalmente entre 250 e 350 nm (LEHNINGER, 1980; ROBBINS, 2002) e diversos danos ao cabelo, como alteração da cor e redução da resistência à tensão, tem sido atribuídos à decomposição de alguns aminoácidos (KHUMALO et al., 2010). Na maioria dos casos, os aminoácidos da cutícula são alterados em uma maior extensão que os presente no córtex, uma vez que estão na camada mais externa da fibra e, portanto, suceptíveis a uma intensidade maior de radiação (ROBBINS, 2012; SANTOS NOGUEIRA; JOEKES, 2004). Uma vez que o córtex é protegido pela cutícula, danos nessa região ocorrem após extensivos danos na camada cuticular. Isso resulta na degradação da cistina e, embora o mecanismo exato desse processo não seja bem conhecido, é sugerido na literatura que essa fotodegradação ocorre via quebra da ligação $\mathrm{C}-\mathrm{S}$ e é diferente da oxidação química da cistina que ocorre principalmente via quebra da ligação S-S (NOGUEIRA; DICELIO; JOEKES, 2006; ROBBINS, 2012).

Ainda em relação aos danos causados na cutícula, cabe salientar que essa camada é rica em ácidos graxos, sendo que o 18-MEA representa cerca de 30-40\% do total desses ácidos graxos (LEE, 2011), que se encontram ligados às proteínas via ligação éster ou tioéster (LEE, 2011; TANAMACHI et al., 2010). Tratamentos químicos em meio alcalino, como alisamentos, permanentes e descoloração, levam a perdas significativas do 18-MEA, o que torna o cabelo mais hidrofílico, vulnerável às agressões diárias e com alterações em sua textura e brilho, além de diminuir o alinhamento das fibras na presença de umidade (HABE et al., 2011; LEE, 2011; OKAMOTO et al., 2012; TANAMACHI et al., 2010). Habe e colaboradores demonstraram que cerca de $90 \%$ do conteúdo total do 18-MEA foi removido após exposição à radiação solar por 480h em um simulador solar, o que corresponde à exposição solar por três meses no verão (HABE et al., 2011). Além disso, esse estudo demonstrou que os tratamentos químicos levam a remoção de proporção semelhante do 18 MEA e outros ácidos graxos presentes na superfície capilar, sendo que os lípides ligados via ligação éster são mais dificilmente removidos, tanto por tratamentos químicos quanto por exposição à radiação solar, quando comparados aos ligados via ligação tioéster (HABE et al., 2011).

Dessa maneira, é possível observar que a radiação UV enfraquece a fibra capilar e esse efeito é acumulativo. Dentre as principais alterações observadas, destacam-se o efeito negativo nas propriedades mecânicas do cabelo (RICHARD BEYAK; KASS; MEYER, 1971) e aumento do intumescimento da fibra quando em contato com solventes (RELE; MOHILE, 2003; ROBBINS, 2012). Em relação às propriedades mecânicas, correlacionadas com resistência e integridade da fibra, a radiação UV diminui a força necessária para romper 
o fio de cabelo e o ângulo de contato dinâmico, o qual indica a hidrofobicidade da fibra. Além disso, observa-se um aumento da força necessária para realização do teste de penteabilidade a úmido e no número de sítios negativos na fibra capilar (NOGUEIRA; DICELIO; JOEKES, 2006). De maneira geral, em relação à aparência física dos cabelos, a radiação solar causa ressecamento, perda de brilho, aumento da fragilidade e alterações na textura da fibra capilar (HABE et al., 2011; LONGO et al., 2013).

A radiação solar, notadamente as frações UVB, UVA e visível, são resposáveis por fotodegradações na fibra capilar. Assim, há o ataque tanto aos pigmentos de melanina presentes na fibra, quanto à fração proteica (queratina) (NOGUEIRA; DICELIO; JOEKES, 2006), sendo que o ataque às proteínas capilares é principalmente atribuido às frações UVB e UVA, com contribuição pouco importante da radiação visível (SIGNORI, 2004).

Ainda em relação à radiação ultravioleta, a oxidação do enxofre do cabelo é atribuida tanto à radiação UVA quanto à UVB. O dano maior ocorre na periferia da fibra, onde existe maior concentração do aminoácido cistina, seguindo para regiões menos oxidadas no interior da fibra (ROBBINS, 2012; RUETSCH; KAMATH; WEIGMANN, 2001).

A quebra fotoquímica das ligações dissulfeto dentro das unidades estruturais da camada A, da exocutícula e da matriz do córtex, juntamente com o estabelecimento de novas ligações cruzadas, intra e intermoleculares, via reação dos grupos carbonil (resultantes da degradação ultravioleta) com grupamentos amino das proteínas, diminuem a diferenciação estrutural da fibra capilar. Com isso, há uma perda gradual da resistência do fio, que se torna mais frágil (ROBBINS, 2012).

\subsection{Danos capilares causados por alisantes químicos}

Os alisantes químicos se destacam entre os agentes que mais causam danos/alterações nos cabelos. No Brasil, a utilização desses produtos é crescente, uma vez que há prevalência de cabelos crespos ou ondulados.

Apesar do conhecimento do uso de formulações alisantes ser amplamente difundido e associado a danos capilares, faltam dados que demonstrem a extensão desses danos com o uso específico desses produtos (BOLDUC; SHAPIRO, 2001; KHUMALO et al., 2010). Sendo assim, a população faz uso desses produtos repetidamente e são submetidas a alterações capilares significativas, que impactam diretamente na saúde e bem-estar. No contexto atual, entretanto, nota-se que os usuários desses produtos possuem maior acesso à informação sobre 
os riscos e consequências a que estão submetidos ao realizarem tratamentos químicos capilares, se comparado ao que ocorria há alguns anos. Isso é relflexo de discussões recentes, divulgadas inclusive pela grande mídia, de riscos envolvendo o emprego de substâncias alisantes, principalmente os compostos por novos ativos (alisamentos em meio ácido), ou seja, diferentes dos tradicionais e permitidos pela legislação vigente do país. Apesar disso, o que se observa é que as pessoas, mesmo que advertidas sobre riscos potenciais, estão dispostas a realizar esses tratamentos químicos.

O grande número de ligações dissulfeto na fibra capilar resulta tanto em resistência, quanto em reatividade seletiva do cabelo. Dessa maneira, essas ligações são o principal alvo da maioria das modificações químicas na fibra capilar, sendo susceptíveis tanto à oxidação quanto à redução. Sabe-se, ainda, que para realização dos alisamentos químicos capilares, é requerido o envolvimento de quase todos os aspectos estruturais do cabelo (WOLFRAM, 1981, 2003).

Existem dois tipos principais de alisamento da fibra capilar: temporário e permanente. A principal diferença desses processos envolve o tipo de ligações desfeitas. No primeiro caso, somente ligações susceptíveis à presença de água são desfeitas, de forma que a manutenção dos fios em um formato diferente do original, pelo uso do secador ou piastra, somente é mantido enquanto o cabelo não for lavado ou exposto à umidade, visto que as ligações originais são refeitas na presença de água. Por outro lado, o alisamento químico envolve a quebra de ligações covalentes, além das ligações secundárias. Dessa maneira, o novo formato das fibras capilares é mantido mesmo após sucessivas lavagens, visto que as ligações dissulfeto que foram desfeitas para a manipulação dos cabelos no formato desejado, não são refeitas em contato com a água (DIAS et al., 2007; MIRANDA-VILELA; BOTELHO; MUEHLMANN, 2014; WOLFRAM, 2003).

Um agente de alisamento comumente empregado é o tioglicolato de amônio, que consiste de um agente redutor capaz de converter as ligações dissulfeto em grupos sulfidrila.. Quando incorporados em emulsões, possuem valores de $\mathrm{pH}$ de 8,5 a 9,5. Esses valores elevados de $\mathrm{pH}$ causam um intumescimento do cabelo, levando à abertura da cutícula e permitindo que o agente alcalino, presente nessas formulações, penetre no fio. Com isso, a fibra torna-se mais maleável e é possível moldá-la no formato desejado. Para fixação do novo formato é necessária uma etapa de neutralização, feita com um agente oxidante, de forma a reconectar as ligações dissulfeto desfeitas na etapa de redução (DIAS et al., 2007, 2008; KUZUHARA, 2003; MIRANDA-VILELA; BOTELHO; MUEHLMANN, 2014; WOLFRAM, 2003). Cerca de $60 \%$ das ligações entre os átomos de enxofre da cistina são desconectadas durante o 
processo, sendo que dessa porcentagem, $90 \%$ são refeitas no etapa oxidativa do procedimento. Ainda é descrito que a utilização de aquecimento favorece a reconstituição da ligação entre os enxofres durante a oxidação (KUZUHARA, 2005).

O uso do tioglicolato de amônio leva a uma quebra específica da ligação dissulfeto, de uma maneira que ela possa ser recombinada ao final do processo. Os alisamentos à base de hidróxidos, por outro lado, são muito menos seletivos, de forma que no processo há uma quebra permanente da ligação dissulfeto. Assim, causam mais danos à fibra, embora posssuam uma eficácia maior quando comparado ao tioglicolato de amônio (WOLFRAM, 2003). Existem diferentes tipos de hidróxidos disponíveis, sendo que o hidróxido de sódio é o que possui maior eficácia no processo de alisamento, mas também a maior intensidade de danos associados (DIAS et al., 2008; WOLFRAM, 2003).

Existem diversos ativos para o alisamento capilar que são permitidos no país, dentre eles o tioglicolato de amônio, hidróxido de sódio, hidróxido de potássio, hidróxido de cálcio, hidróxido de lítio e hidróxido de guanidina. Em relação aos hidróxidos, o mais comumente empregado é o Hidróxido de Guanidina, resultante da reação entre o Hidróxido de Cálcio e Carbonato de Guanadina (DIAS et al., 2008; MIRANDA-VILELA; BOTELHO; MUEHLMANN, 2014). Todos esses ativos mencionados causam um processo de lantionização no cabelo. Nesse processo, cerca de 35\% do conteúdo de cistina é convertido em lantionina, que é o principal produto de reação entre a cistina e um álcali. Esse produto é análogo da cistina, diferenciando-se pela perda de um átomo de enxofre, e possui importância na manutenção da configuração do cabelo no formato liso. Entretanto, essa conversão de cistina para lantionina leva a um enfraquecimento da fibra capilar, tornando-a mais vulnerável à quebra (MIRANDA-VILELA; BOTELHO; MUEHLMANN, 2014; WOLFRAM, 2003).

Sabe-se que nas fibras não tratadas quimicamente, as camadas das células da cutícula encontram-se intimamente ligadas umas às outras, o que facilita a execução do ato de pentear, além de possuirem maior resistência à quebra devido, principalmente, à estruturação das cadeias de queratina, por meio das ligações dissulfeto (WORTMANN; SCHWANJONCZYK, 2006). Entretanto, procedimentos químicos, tais como tinturas e alisamentos, podem modificar essa conformação dos cabelos, tornando-os quebradiços e ásperos ao toque. Essa é uma alteração comum a todos os tipos de agentes químicos empregados para realização dos alisamentos capilares, embora os danos ocorram em diferentes extensões, dependendo da força do ativo (DIAS et al., 2007; MIRANDA-VILELA; BOTELHO; MUEHLMANN, 2014). 


\section{4 Óleos vegetais e sua aplicação em cosméticos capilares}

O uso de plantas é tão antigo quanto a humanidade. Na Ásia e na África, os óleos vegetais são comumente usados sob a forma de pomadas capilares, que são conhecidas por proporcionar uma aparência saudável aos cabelos (KEIS et al., 2005). Os vegetais já foram a principal fonte e origem de cosméticos, antes que métodos empregados para síntese de substâncias com propriedades similares fossem descobertos. Apesar disso, nem sempre é possível substituir os compostos naturais pelos sintéticos, haja vista a grande complexidade química desses ativos de origem vegetal (ABURJAI; NATSHEH, 2003).

Embora o emprego de ativos naturais tenha inúmeras vantagens, existem, também, alguns fatores limitantes, como, por exemplo, variações na cor, odores, transparência e teor do ingrediente ativo. Em 1997, relatava-se sobre a ausência de referências científicas e dificuldade de fundamentação, com textos oficiais de farmacognosia ou etnofarmacêuticos, dos dados divulgados pelos fornecedores de matérias-primas (DWECK, 1997). Com um maior controle das etapas de obtenção desses ativos naturais e com processos mais tecnológicos, os ingredientes de origem vegetal voltaram a se destacar no contexto da indústria cosmética. Em 2003, estudos já apontavam a tendência em um aumento significativo de novos produtos no mercado contendo óleos e outros derivados vegetais (ABURJAI; NATSHEH, 2003). Em 2005, ainda se falava do uso progressivo de óleos naturais em produtos para os cuidados da pele e cabelos (KEIS et al., 2005). Mais recentemente, observase que os ingredientes naturais estão continuamente ganhando popularidade, com o aumento do uso de extratos e outros derivados vegetais em formulações cosméticas. Além disso, existe um maior volume de publicações com comprovação científica dos efeitos benéficos desses componentes naturais e de seu uso etnobotâncio. Consequentemente, já existem no mercado matérias-primas com melhor qualidade, uma vez que estão disponíveis técnicas mais robustas e eficientes de extração, isolamento e produção desses componentes em grande escala (ABURJAI; NATSHEH, 2003; ANWAR et al., 2007; FARIA et al., 2013; FERNÁNDEZ et al., 2012b; KEIS; HUEMMER; KAMATH, 2007; O’LENICK; O’LENICK, 2005). Associado a isso, existe uma demanda dos consumidores e, portanto, do mercado, por produtos naturais, os quais possuem boa aceitação quando incorporados em produtos cosméticos (MORAIS; OLIVEIRA; ROCHA-FILHO, 2014)

Em relação aos cuidados dos cabelos, são atribuídas diversas aplicações dos ativos vegetais, sendo utilizados como estimulantes do crescimento capilar, tinturas e para tratamento dos fios e couro cabeludo, além da prevenção da alopecia (ABURJAI; NATSHEH, 
2003; KAMEYAMA, 1995). Como exemplo, as protocianidinas extraídas das sementes de uva são associadas à proliferação in vitro das células do folículo piloso, além de estudos sugerindo que o extrato das folhas de Ginkgo biloba promove o crescimento celular e o estímulo do crescimento capilar utlizando géis contendo Aloe vera. Tratando-se especificamente dos óleos vegetais, a sua deposição nos cabelos tem sido associada a um efeito benéfico protetor e melhora das propriedades sensoriais do fio, como brilho e textura (KEIS; HUEMMER; KAMATH, 2007; KEIS et al., 2005).

Os óleos vegetais consistem de triglicerídeos com uma variedade de ácidos graxos que diferem no tamanho da cadeia (número de átomos de carbono na molécula), grau de saturação, posicionamento das ligações duplas nas cadeias carbônicas e geometria de cada ligação dupla (isômeros cis ou trans) (ABDULKARIM et al., 2007). Assim, a habilidade dos óleos vegetais em promover condicionamento está relacionada a essas diferentes propriedades, além de suas características moleculares, como energia de superfície e forças coesivas (JACHOWICZ, 1999). A composição de cada óleo depende da sua origem e há uma grande variedade de óleos naturais com propriedades distintas, devido aos seus diferentes perfis de composição lipídica, sendo que o ácido oleico é o ácido graxo monoinsaturado mais abundante na maioria dos óleos comuns (ANWAR et al., 2007; GUNSTONE, 2002).. (VERMAAK et al., 2011).

A composição rica em vitaminas e ácidos graxos do óleo de abacate, torna-o um excelente agente condicionante para todos os tipos de cabelo e seu efeito hidratante é muito útil para aplicação em cabelos ressecados. Evidências consistentes indicam que a Vitamina E, presente neste óleo, pode ser um importante agente para proteger cabelos e couro cabeludo contra ressecamento e quebra do fio por escovação ou tratamentos químicos. Tem sido demonstrado que a Vitamina E é diretamente absorvida pelo córtex capilar, sendo que a absorção mostrou ser acumulativa e melhor em cabelos danificados do que em cabelos saudáveis (IDSON, 1993).

O óleo de abacate possui altas concentrações de ácido oleico (Tabela 2) e quantidades substanciais de compostos benéficos a saúde, como fitoesteróis e vitaminas (REQUEJO et al., 2003). Comparado com outros frutos, o abacate contém uma alta concentração de esteróis. Os fitoesteróis são compostos triterpênicos, similares estruturalmente ao colesterol, que são encontrados nas plantas. Esses compostos estão associados à atividade anticâncer, antiinflamatória, antiaterogência e antioxidante (BERGER; JONES; ABUMWEIS, 2004). Além disso, são ricos em ácidos graxos insaturados, os quais são menos estáveis a oxidação quando comparados a ácidos graxos saturados (BERASATEGI et al., 2012; CHOE; MIN, 2007). 
Outro óleo de grande interesse cosmético é o óleo de moringa. É indicado como um dos óleos vegetais mais estáveis disponível, o que possibilita proteção contra a rancificação das formulações ao longo do tempo ou quando expostas a elevadas temperaturas. A presença do ácido berrênico resulta em formulações com características muito desejáveis: grande emoliência mas sem o aspecto pegajoso após a aplicação (KLEIMAN; ASHLEY; BROWN, 2008).

Nativa de regiões do Sub-Himalaia do noroeste da India, a espécie Moringa oleifira é também encontrada em muitos países na África, Arábia, Sudeste da Ásia, Ilhas Caribenhas e América do Sul (ANWAR et al., 2007).

As árvores tem altura de 5 a 10 metros e algumas vezes até 15 metros (SOMALI; BAJNEDI; AL-FHAIMANI, 1984). Cresce bem nos trópicos com alta umidade e também em lugares muito secos e quentes, sendo pouco afetadas por períodos de seca. Variações no conteúdo dos óleos provenientes de diferentes regiões são atribuídas a mudanças nas condições ambientais e geológicas (ANWAR; BHANGER, 2003; IBRAHIM et al., 1974). As folhas, flores, frutos e raízes dessa árvore são localmente muito apreciadas por suas propriedades nutricionais (ANWAR; BHANGER, 2003). Também é associada a benefícios medicinais, sendo utilizada no tratamento da ascite, reumatismo e como estimulante cardíaco e circulatório (ANWAR; ASHRAF; BHANGER, 2005).

Vários estudos tem sido conduzidos para caracterização do óleo da Moringa oleifira (ABDULKARIM et al., 2005; ANWAR; ASHRAF; BHANGER, 2005; TSAKNIS, 2010; TSAKNIS et al., 1998). É reportado como tendo alto teor de ácido oleico e diferentes isômeros de tocoferol (ANWAR; ASHRAF; BHANGER, 2005) (Tabela 2).

Tabela 2- Composição de ácido graxos (\%) em diferentes óleos vegetais

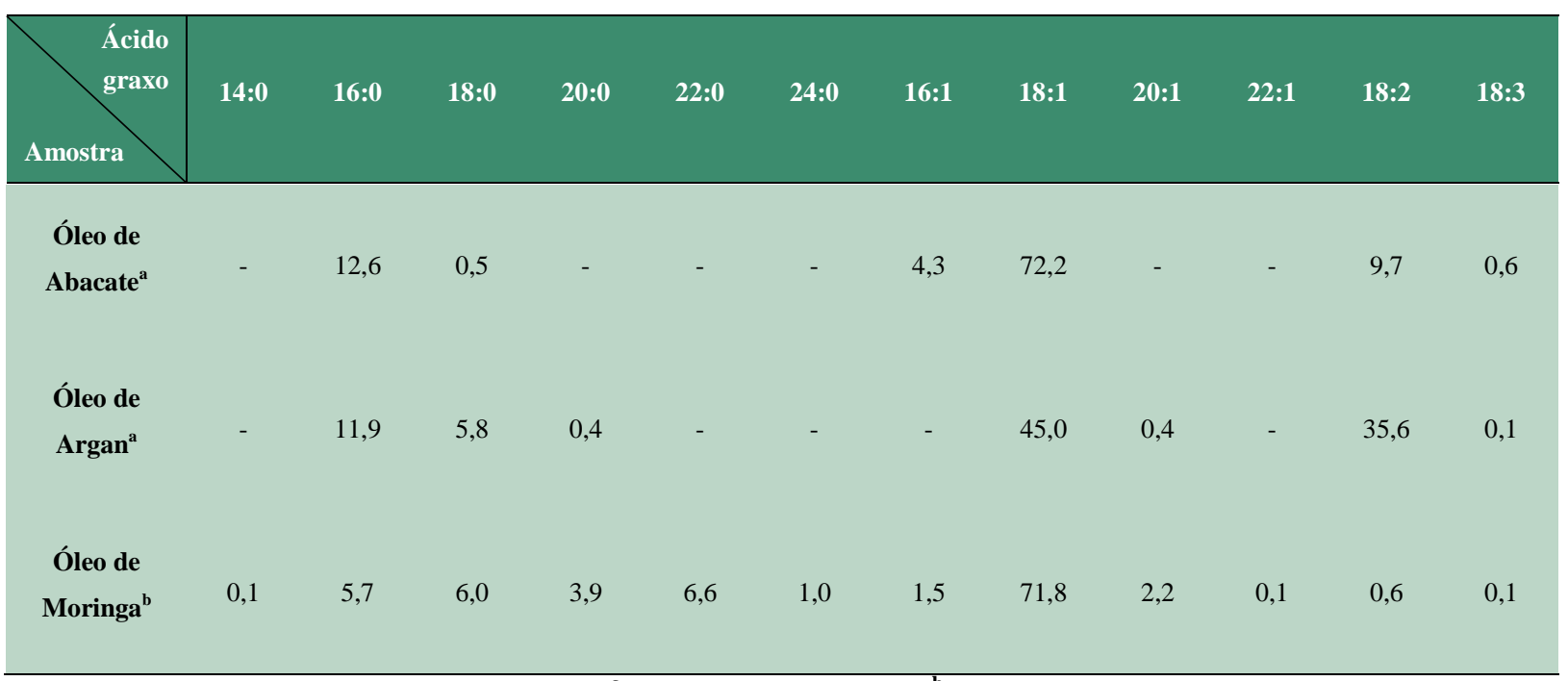

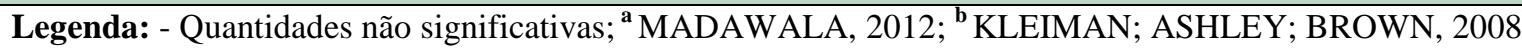


O óleo de argan é outro óleo comumente utilizado, sendo produzido com duas funções principais: comestível e produtos cosméticos. O óleo de argan para uso em cosméticos é preparado industrialmente, principalmente na Europa, por extração com solvente dos frutos importados (GUILLAUME; CHARROUF, 2011b).

A árvore de argan é uma árvore de cresimento lento exclusivamente endêmica nas terras áridas do sudoeste do Marrocos. Seu frutos, dos quais provém o óleo, requerem um processamento de várias etapas, que se inicia com a sua secagem (HARHAR; GHARBY; KARTAH, 2010), com um rendimento de até 35\% de produção de óleo. Entretanto, melhoramentos no processo de extração resultaram em rendimento de até $60 \%$. Tradicionalmente, o óleo de argan era usado extensivamente no Marrocos para tratamento de diversos problemas como pele seca, acne, psoríase, eczema, rugas, dores nas articulações e inflamações cutâneas (CHARROUF; GUILLAUME, 1999). Para os cabelos, os principais usos eram na prevenção da queda e ressecamento capilar (CHARROUF; GUILLAUME, 1999). É Composto por $99 \%$ de acilglicerídeos, primariamente triglicerídeos. O material insaponificável, que representa o $1 \%$ remanescente, é composto por carotenos, tocoferóis, alcoóis triterpênicos, esteróis e xantofilas (CHARROUF; GUILLAUME, 1999).

Ácidos graxos que compõem os acilgliceróis são principalmente o ácido oleico (monoinsaturado, pertencente à família ômega 9) e linoleico (poli-insaturado, pertencente à família ômega 6) (Tabela 2) (RAHMANI, 2005).

Algumas das propriedades farmacológicas do óleo de argan são resultantes de seu conteúdo de ácidos graxos insaturados. Entretanto, diversos outros óleos são ricos em ácido oleico ou linoleico, mas não possuem os mesmos efeitos terapêuticos. Muitos dos efeitos específicos do óleo de argan são atribuídos a sua composição de material insaponificável. O conteúdo de tocoferol é $620 \mathrm{mg} / \mathrm{Kg}$, uma valor elevado quando comparado, por exemplo, ao óleo de oliva, que possui $320 \mathrm{mg} / \mathrm{Kg}$ (GUILLAUME; CHARROUF, 2011a). Os tocoferóis são moléculas com forte poder antioxidante e sequestrante de radicais livres. Gammatocoferol é o mais eficiente dentre todos os tocoferóis (JIANG et al., 2001), compondo 69\% do conteúdo total de tocoferol do óleo de argan (GUILLAUME; CHARROUF, 2011b)

O óleo de argan possui aplicações cosméticas como hidratação e reparação capilar. Muito dos efeitos atribuídos a utilização desse óleo, resultam do uso popular e, embora haja pouco respaldo científico acerca dos efeitos cosméticos, os benefícios relativos ao seu uso são bem disseminados (GUILLAUME; CHARROUF, 2011a). 


\subsection{Desenvolvimento de Formulações Cosméticas Capilares}

Os produtos cosméticos são desenvolvidos de forma a restaurar a maleabilidade do cabelo, ao diminuir a eletricidade estática e reduzir a fricção entre os fios, devolver a maciez e recondicionar a fibra danificada, que é mais porosa e hidrofílica (BOLDUC; SHAPIRO, 2001).

A principal função dos agentes condicionadores é proteger os elementos estruturais do cabelo, especialmente a cutícula, dos efeitos dos cuidados diários, correspondentes ao termo grooming do inglês, tais como ato de pentear e lavar os cabelos, além dos danos ambientais, como radiação solar e vento, e químicos, como colorações e alisamentos. Todos esses fatores levam a fragmentação e perda de células cuticulares (GARCIA; EPPS; YARE, 1978; KELLY; ROBINSON, 1982; TATE; KAMATH; RUETSCH, 1993). A melhora da textura dos fios e maior facilidade para penteá-los são apontadas como funções primárias das formulações cosméticas capilares. As funções secundárias são prevenir o efeito "flighway", resultante da eletricidade estática, aumentar o brilho dos cabelos e protegê-lo contra danos futuros, ao formar uma fina camada de revestimento sobre a fibra (BHUSHAN, 2008).

Os principais constituintes das formulações, do tipo emulsões, para tratamentos capilares são tensoativos catiônicos, álcoois graxos, silicones e água. Esses contituintes facilitam a penteabilidade dos fios e melhoram sua aparência em geral. Outros ativos, como proteínas, filtros solares, antioxidantes, também podem ser adicionados de forma a proteger os cabelos de danos futuros, repará-los e melhorar suas características sensoriais (BHUSHAN, 2008; DRAELOS, 2013).

Sabe-se que os tratamentos químicos e radiação solar podem causar significativos danos à fibra capilar (HORIRICHI, 1978; KAPLIN; SCHWANN; ZAHN, 1982; SANDHU; RAMACHANDRAN; ROBBINS, 1995; TATE; KAMATH; RUETSCH, 1993), modificando a superfície do cabelo, introduzindo cargas negativas como resultado da oxidação da cistina em ácido cisteico (FERNÁNDEZ et al., 2012b; HORIRICHI, 1978; KAPLIN; SCHWANN; ZAHN, 1982; ROBBINS, 2012; TATE; KAMATH; RUETSCH, 1993). Com isso, pode ocorrer a transformação completa da superfície da fibra capilar de hidrofóbica para hidrofílica (REICH et al., 2009), levando a um aumento da fricção na superfície (JACHOWICZ, 1999; ROBBINS, 2012; SCHWATZ; KNOWLES, 1963; SCOTT; ROBBINS, 1980) e na força necessária para pentear os cabelos. Por tudo isso, cabelos quimicamente tratados e danificados pela radiação ultravioleta requerem mais condicionamento quando comparado ao cabelo 
virgem e já foi demonstrado que as células cuticulares nos cabelos danificados estão em melhores condições quando há o uso de condicionadores (REICH et al., 2009) 
3. Objetivo 


\subsection{Objetivo Geral}

Desenvolver formulações cosméticas contendo óleos vegetais para proteção e tratamento de cabelos danificados pela radiação solar ou por alisamento químico.

\subsection{Objetivos Específicos}

- Desenvolver formulações contendo óleo de abacate, argan e moringa, isolados e associados, para o tratamento e reparação de cabelos submetidos ao alisamento químico.

- Selecionar, dentre as formulações desenvolvidas, a que apresentar os melhores resultados na análise sensorial e nos testes de resistência mecânica.

- Realizar estudo reológico das formulações com melhores resultados nas avaliações anteriores, variando a composição do agente de consistência e da base autoemulsionante, para escolha das formulações finais.

- Verificar, por meio de técnicas analíticas e de imagem, se as formulações finais foram eficazes na proteção ou reparação das mechas de cabelo submetidas à radiação solar. 
4.Material e Métodos 


\subsection{Matérias-primas}

As matérias-primas estão de acordo com o INCI (International Nomemclature of Cosmetic Ingredient). Foram mencionados ainda o nome comercial e o fornecedor/fabricante.

- Amodimethicone (and) Cetrimonium Chloride (and) Trideceth-12, Dow Corning ${ }^{\circledR}$ 949Dow Corning;

- Amodimethicone (and) C11-15 Pareth-7 (and) Laureth-9 (and) Glycerin (and) Trideceth12, Dow Corning ${ }^{\circledR}$ CE-8170- Dow Corning;

- Aqua, EDTA, Methylparaben, Propylene Glycol, Cetearyl Alcohol, Ceteareth-20, Cetrimonium Chloride, Ammonnium Thioglycolate, Ammonium Hidroxide, Lanolin,Cetearyl Alcohol (and) Dicetyl Phosphate (and)Ceteth-10 Phosphate, Hydrolyzed Rhodophycea Extract, Behentrimonium Methosulfate (and) Quaternium 33 (and) Cetyl Alcohol, Parfum, Paraffinnum Liquidum. Alisante de Mercado com Tioglicolato de Amônio - Grandha;

- Aqua, Methylparaben, Propilene Glycol, Propylparaben, Ceteareth-20, Paraffinnum Luquidum, Cetrimonium Chloride, Calcium Hydroxide, Cetyl Alcohol, Petrolatum, Glyceril Stearate, Cetearyl Alcohol (and) Dicetyl Phosphate (and) Ceteth-10 phosphate, Astocaryum Murumuru Butter, Carnauba Wax, Emulsão A/O contendo Hidróxido de Cálcio - Grandha; Aqua, Hidroxyethylcellulose, Guanidine Carbonate, Líquido ativador contendo Carbonato de Guanidina - Grandha;

- Aqua - Glycerin - PEG-8 - PEG-8/SMDI Copolymer - Palmitoyl Myristyl Serinate Sodium Polyacrylate, Ceramide A $2^{\circledR}$ - Sederma/Croda;

- Aqua (and) Hydrolyzed Vegetable Protein - PG-Propyl Silanetriol, Keravis ${ }^{\circledR}$ - Croda;

- Argania Sideroxylon (Argan) Oil, Beraoil V2700 - Beraca;

- Behentrimonium Methosulfate (and) Cetyl Alcohol (and) Butylene Glycol, Incroquat ${ }^{\circledR}$ Behenyl TMS-50 - Croda;

- BHT- Sterlitamak;

- Bis-Diisopropanol-amino-PG-propyl Dimethicone/ Bis-Isobutyl PEG-14 Copolymer (and) polysorbate 20 (and) Butyloctanol, Dow Corning ${ }^{\circledR}$ CE-8411 - Dow Corning;

- Caprylic/Capric Triglyceride, Crodamol GTCC ${ }^{\circledR}$ - Croda;

- Cetearyl Alcohol, Alkonat 1618 C $30^{\circledR}$ - Oxiteno;

- Cetearyl Alcohol and Dicetyl Phosphate and Ceteth-10 Phosphate, Crodafos CES ${ }^{\circledR}$ Croda;

- $\quad$ Cetrimonium Chloride, Incroquat ${ }^{\circledR}$ CTC-30 - Croda; 
- Cetyl Esters, Crodamol SS ${ }^{\circledR}-$ Croda;

- Cinnamidopropyltrimonium Chloride, Crodasorb ${ }^{\circledR}$ UV-283 - Croda;

- C10-40 Isoalkylamidopropylethyldimonium Ethosulfate (and) Dipropylene Glycol, Cutissential $^{\circledR}$ 18-MEA 40- Croda;

- EDTA - Shijiazhuan Jackchel;

- Moringa Oleifera Seed Oil, Floralipids Moringa Oil - Cosmotec;

- Persea Gratissima (Avocado) Oil, Beraoil V0110- Beraca;

- Persea Gratissima (Avocado) Oil, Aceite de Aguacate - Provital Group;

- Phenoxyethanol (and) Methylparaben (and) Ethylparaben (and) Butylparaben (and)

Propylparaben (and) Isobutylparaben, Phenova - Croda;

- PPG-3 Benzyl Ether Ethylhexanoate, Crodamol SFX ${ }^{\circledR}$ - Croda;

- Propylene Glycol - Lyondell;

- Silicone Quaternium-16 (and) Undeceth-11 (and) Butyloctanol (and) Undeceth-5, Dow Corning ${ }^{\circledR}$ 5-7113- Dow Corning;

\subsection{Equipamentos e Acessórios}

- $\quad$ Agitador Mecânico 713D (Fisatom);

- Balança analítica BL 320H (Shimadzu),;

- Balança eletrôncia AS 2000C (Marte);

- Câmara para testes com Xenon Q-SUN Xe-3 (Q-Lab);

- Centrífuga - Excelsa Baby II, modelo 206-R;

- Chapa de Aquecimento;

- Chromameter ${ }^{\circledR}$ CR-400 (Konica Minolta Sensing);

- Embalagens plásticas de PVC opacas, com capacidade para 20 gramas;

- Fluorímetro Fluorescence Spectrophotometer, modelo F-4500 (Hitachi);

- Máquina universal para ensaios mecânicos, modelo DL 2000 (EMIC), dotado de célula de carga com capacidade de $10 \mathrm{kgf}$;

- Micrômetro Digital (Mitutoyo);

- Microscópio Eletrônico de Varredura EVO 50 (Zeiss);

- Peagômetro DM 20 (Digimed);

- Pulverizador de ouro SCD 050 Sputter Coater (Bal-Tec);

- Reômetro DV-III digital, tipo Cone \& Placa (BROOKFIELD), acoplado ao software Rheocalc $^{\circledR}$ versão V1.01 e spindle CP 52; 
- $\quad$ Skin-colorimeter ${ }^{\circledR}$ CL 400 (Courage-Khazaka);

- Termômetro;

- $\quad$ Texturômetro Analyser ${ }^{\circledR}$ modelo TAXT2 (Stable Micro Systems ${ }^{\circledR}$ Texture Expert Exceed).

- Vidrarias em geral;

\subsection{Mechas de Cabelo}

- Mechas de cabelo virgem do tipo cacheado castanho escuro, adquiridas da empresa especializada em vendas de cabelo, Andrea Lopes Cabelos ${ }^{\circledR}$ (São Paulo, Brasil), empregadas na primeira etapa do estudo, que consistiu na aplicação de formulações para alisamento químico.

- Mechas de cabelo do tipo extra curly castanho escuro, fornecidas pela empresa De Meo Brothers Inc (New York, EUA), empregadas na segunda etapa do estudo, que consistiu na exposição das mechas à radiação solar.

\subsection{Desenvolvimento de Formulações}

Foram desenvolvidas formulações na forma de cremes de pré-tratamento e pós-tratamento com enxágue (rinse off). As fases Oleosa (Fase A) e Aquosa (Fase B), foram pesadas e aquecidas separadamente à uma temperatura de $75 \pm 5^{\circ} \mathrm{C}$. O método empregado para o preparo foi o EPI (Emulsion Phase Inversion). A Fase aquosa foi vertida lenta e continuamente sobre a Fase Oleosa, sob agitação constante empregando Agitador Mecânico Fisatom, Modelo $713 \mathrm{D}$, até que atingisse temperatura ambiente controlada $\left(25 \pm 2^{\circ} \mathrm{C}\right)$. Foi utilizada velocidade de rotação de 300 e $600 \mathrm{rpm}$. As demais fases foram adicionadas separadamente, em intervalos regulares, somente após a formulação atingir temperatura inferior a $40^{\circ} \mathrm{C}$.

A descrição das matérias-primas selecionadas para compor as formulações encontra-se a seguir, segundo informe técnico disponiblizados pelo fabricante.

Cetearyl Alcohol and Dicetyl Phosphate and Ceteth-10 Phosphate (Crodafos CES ${ }^{\circledR}$ ): mistura finamente balanceada de ácidos graxos e ésteres fosfato, constituindo um sistema emulsificante e condicionador sinérgico.

Behentrimonium Methosulfate (and) Cetyl Alcohol (and) Butylene Glycol (Incroquat Behenyl TMS 50): é uma cera autoemulsionante catiônica, obtida a partir de um sal de amina 
quaternária derivada do óleo de colza (rapeseed oil). Sabe-se que quanto maior a cadeia de carbonos, menor a irritação para pele.

Cetearyl Alcohol (Alkonat $1618 \mathrm{C30}^{\circledR}$ ): atua como agente de consistência e emoliente. PPG-3 Benzyl Ether Ethylhexanoate, $\left(\right.$ Crodamol SFX $\left.{ }^{\circledR}\right)$ : Devido ao alto índice de refração, é atribuido ao uso dessa matéria-prima um aumento de brilho nos fios de cabelo. Isso ocorre devido a formação de um filme na superfície, possibilitando um melhor alinhamento da fibra capilar e diminuindo o ângulo da cutícula. É informado, também, que o uso dessa matériaprima oferece benefícios sensoriais, com boa espalhabilidade e efeito não pegajoso.

Caprylic/Capric Triglyceride: mistura de triglicerídeos de cadeia média constituídos principalmente de ésteres dos ácidos cápricos e caprílicos, derivados do óleo de coco. É utilizado como emoliente em formulações cosméticas. Possui compatibilidade com óleos vegetais, silicones e ésteres sintéticos e boa capacidade como diluente e ativos.

Cetyl Esters (Crodamol SS ${ }^{\circledR}$ ) Éster sólido com estrutura cristalina que oferece mais emoliência e mais "corpo" em formulações cosméticas e farmacêuticas. É atribuído a ele, a formação de cremes brancos muito estáveis. Consiste de uma mistura de estearato, palmitato e miristato de cetila.

Aqua (and) Hydrolyzed Vegetable Protein - PG-Propyl Silanetriol (Keravis ${ }^{\circledR}$ ): copolímero de proteínas vegetais hidrolisadas e silicone, capaz de penetrar no córtex do fio e também formar um filme na superfície.

Cinnamidopropyltrimonium Chloride (Crodasorb $^{\circledR}$ UV-283): protetor UV quaternizado, produzido para proteger o cabelo do sol. Atribuído a uma melhora significativa das propriedades de penteabilidade, força e propriedades mecânicas do cabelo exposto a radiação UV.

Silicones: foram selecionados diversos silicones que, de acordo com informações do fabricante, forneciam características desejáveis ao cabelo, como melhora na resistência de cabelos quimicamente tratados, aumento do brilho e melhora nas propriedades sensoriais.

Aqua - Glycerin - PEG-8 - PEG-8/SMDI Copolymer - Palmitoyl Myristyl Serinate Sodium Polyacrylate (Ceramide A $2^{\circledR}$ ): análogo químico da Ceramida 2, uma molécula natural encontrada no cabelo. O emprego da ceramida é atribuído a um reforço estrutural, proteção e revestimento do cabelo danificado, melhorando a resistência, o brilho e o vigor dos cabelos.

Cetrimonium Chloride: Agente antiestático, com uma carga positiva capaz de neutralizar cargas negativas presentes no cabelo. Classificado como um tensoativo catiônico sob a forma de composto quaternário de amônio, é um dos agentes condicionantes mais comuns em produtos comerciais (HUNTING, 1987; QUACK, 1976; REICH et al., 2009). 
Outros componentes: para finalizar a escolha dos componentes das formulações desenvolvidas, utilizou-se o propilenoglicol como agente umectante e dispersante; EDTA dissódico como agente quelante; BHT como antioxidante da formulação; Phenoxyethanol (and) Methylparaben (and) Ethylparaben (and) Butylparaben (and) Propylparaben (and) Isobutylparaben, como agente conservante. Solução de ácido cítrico a $10 \%$ e $\mathrm{AMP}^{\circledR}$, foram empregados para ajuste do $\mathrm{pH}$.

As primeiras composições desenvolvidas encontram-se descritas a seguir (Tabela 3). Todas as formulações da etapa de pré-tratamento foram desenvolvidas com a adição do filtro solar empregado neste estudo, o Cinnamidopropyltrimonium Chloride.

As formulações de Pré-tratamento (FPE), FPE1, FPE2, FPE3 FPE4, foram desenvolvidas com as mesmas matérias-primas, variando apenas as proporções entre a base auto emulsionante e o agente de consistência. Já as formulações FPE5 e FPE6, foram desenvolvidas com a adição ou não da matéria-prima Cetil Esters, a fim de verificar alteração na aparência e consistência da formulação. As formulações FPE7 e FPE8 foram desenvolvidas com outra base autoemulsionante, Cetearyl Alcohol and Dicetyl Phosphate and Ceteth-10 Phosphate. Foi utilizada solução a 10\% de ácido cítrico como agente de correção do $\mathrm{pH}$. 
Tabela 3: Composição das formulações de pré-tratamento contendo óleo de argan, abacate e moringa, desenvolvidas na etapa inicial.

\begin{tabular}{|c|c|c|c|c|c|c|c|c|}
\hline \multirow{2}{*}{ Componentes } & \multicolumn{6}{|c|}{ Composição \%(p/p) } & \multirow[b]{2}{*}{ FPE7 } & \multirow[b]{2}{*}{ FPE8 } \\
\hline & FPE1 & FPE2 & FPE3 & FPE4 & FPE5 & FPE6 & & \\
\hline \multicolumn{9}{|l|}{ Fase A } \\
\hline $\begin{array}{l}\text { Álcool Cetoestearílico } \\
30 / 70\end{array}$ & 2,0 & 2,0 & 4,0 & 3,0 & 3,0 & 3,0 & 3,0 & 3,0 \\
\hline $\begin{array}{l}\text { Behentrimonium } \\
\text { Methosulfate (and) Cetyl } \\
\text { Alcohol (and) Butylene } \\
\text { Glycol }\end{array}$ & 3,0 & 4,0 & 3,0 & 4,0 & 3,0 & 3,0 & - & - \\
\hline $\begin{array}{l}\text { Cetearyl Alcohol and } \\
\text { Dicetyl Phosphate and } \\
\text { Ceteth-10 Phosphate }\end{array}$ & - & - & - & - & - & - & 5,0 & 6,0 \\
\hline Cetil ésteres & 3,0 & 3,0 & 3,0 & 3,0 & 3,0 & - & 3,0 & 3,0 \\
\hline $\begin{array}{l}\text { Triglicerídeos dos Ácidos } \\
\text { Cáprico e Caprílico }\end{array}$ & 2,0 & 2,0 & 2,0 & 2,0 & 2,0 & 2,0 & 2,0 & 2,0 \\
\hline Óleo de Abacate & 0,5 & 0,5 & 0,5 & 0,5 & 0,5 & 0,5 & 0,5 & 0,5 \\
\hline Óleo de Argan & 0,5 & 0,5 & 0,5 & 0,5 & 0,5 & 0,5 & 0,5 & 0,5 \\
\hline Óleo de Moringa & 0,5 & 0,5 & 0,5 & 0,5 & 0,5 & 0,5 & 0,5 & 0,5 \\
\hline BHT & 0,05 & 0,05 & 0,05 & 0,05 & 0,05 & 0,05 & 0,05 & 0,05 \\
\hline Fenoxietanol e parabenos & 0,8 & 0,8 & 0,8 & 0,8 & 0,8 & 0,8 & 0,8 & 0,8 \\
\hline \multicolumn{9}{|l|}{ Fase B } \\
\hline $\begin{array}{l}\text { Cloreto de cetil trimetil } \\
\text { amônio }\end{array}$ & 1,0 & 1,0 & 1,0 & 1,0 & 1,0 & 1,0 & 1,0 & 1,0 \\
\hline Propilenoglicol & 1,5 & 1,5 & 1,5 & 1,5 & 1,5 & 1,5 & 1,5 & 1,5 \\
\hline EDTA dissódico & 0,1 & 0,1 & 0,1 & 0,1 & 0,1 & 0,1 & 0,1 & 0,1 \\
\hline Água Deionizada & 73,55 & 72,55 & 71,55 & 71,55 & 72,55 & 75,55 & 70,55 & 69,55 \\
\hline \multicolumn{9}{|l|}{ Fase C } \\
\hline $\begin{array}{l}\text { Aqua - Glycerin - PEG- } 8 \text { - } \\
\text { PEG-8/SMDI Copolymer - } \\
\text { Palmitoyl Myristyl Serinate } \\
\text { - Sodium Polyacrylate }\end{array}$ & 2,0 & 2,0 & 2,0 & 2,0 & 2,0 & 2,0 & 2,0 & 2,0 \\
\hline Propilenoglicol & 2,0 & 2,0 & 2,0 & 2,0 & 2,0 & 2,0 & 2,0 & 2,0 \\
\hline \multicolumn{9}{|l|}{ Fase D } \\
\hline $\begin{array}{l}\text { Aqua (and) Hydrolyzed } \\
\text { Vegetable Protein }\end{array}$ & 0,5 & 0,5 & 0,5 & 0,5 & 0,5 & 0,5 & 0,5 & 0,5 \\
\hline \multicolumn{9}{|l|}{ Fase $\mathbf{E}$} \\
\hline $\begin{array}{l}\text { Amodimethicone (and) } \\
\text { Cetrimonium Chloride } \\
\text { (and) Trideceth-12 }\end{array}$ & 4,0 & 4,0 & 4,0 & 4,0 & 4,0 & 4,0 & 4,0 & 4,0 \\
\hline \multicolumn{9}{|l|}{ Fase $\mathbf{F}$} \\
\hline $\begin{array}{l}\text { Cinnamidopropyltrimonium } \\
\text { Chloride }\end{array}$ & 3,0 & 3,0 & 3,0 & 3,0 & 3,0 & 3,0 & 3,0 & 3,0 \\
\hline \multicolumn{9}{|l|}{ Fase $\mathbf{G}$} \\
\hline Ácido cítrico q.s. & - & - & - & - & - & - & $\mathrm{pH} 4,5$ & $\mathrm{pH} 4,5$ \\
\hline
\end{tabular}

Para todas as formulações descritas, foram elaborados os seus respectivos veículos, contendo as mesmas proporções de matéria-prima, porém sem a presença dos três óleos 
vegetais e do Cinnamidopropyltrimonium Chloride, que é o filtro solar adicionado a essas formulações.

Para o desenvolvimento das formulações de pós-tratamento (FPO), foi seguido protocolo semelhante ao descrito para a etapa de pré-tratamento. Entretanto, a base auto emulsionante empregada foi somente o Behentrimonium Methosulfate (and) Cetyl Alcohol (and) Butylene Glycol. Dessa forma, as formulações FPO1, FPO2, FPO3, FPO4, FPO5, FPO6, foram preparadas com as mesmas matérias-primas, variando-se apenas a proporção de base autoemulsionante e agente de consistência. Nessa etapa o Cinnamidopropyltrimonium Chloride não foi adicionado à composição da formulação, uma vez que para a etapa de póstratamento o obejtivo principal foi a reparação do dano químico e causado pela radiação ultravioleta. Para isso, foi adiconada à formulação o agente condicionante contendo o ácido 18-metileicosanóico.

A composição das formulações desenvolvidas nessa etapa estão descritas a seguir (Tabela 4). Da mesma forma, foram preparados os respectivos veículos, que eram compostos pelas mesma matérias-primas, nas mesmas concentrações, porém sem adição dos três óleos vegetais. $\mathrm{O}$ agente condicionante contendo o ácido 18-metileicosanóico (C10-40 Isoalkylamidopropylethyldimonium Ethosulfate (and) Dipropylene Glycol) foi adicionado também no veículo, de forma que somente os óleos vegetais foram considerados ingredientes ativos nas formulações desenvolvidas. 
Tabela 4- Composição das formulações de pré-tratamento contendo óleo de argan, abacate e moringa desenvolvidadas na etapa inicial.

\begin{tabular}{|c|c|c|c|c|c|c|}
\hline \multirow{2}{*}{ Componentes } & \multicolumn{6}{|c|}{ Composição \%(p/p) } \\
\hline & FPO1 & FPO2 & FPO3 & FPO4 & FPO5 & FPO6 \\
\hline \multicolumn{7}{|l|}{ Fase A } \\
\hline Álcool Cetoestearílico 30/70 & 2,0 & 3,0 & 4,0 & 5,0 & 3,0 & 3,0 \\
\hline $\begin{array}{l}\text { Behentrimonium Methosulfate } \\
\text { (and) Cetyl Alcohol (and) Butylene } \\
\text { Glycol }\end{array}$ & 5,0 & 4,0 & 3,0 & 2,0 & 3,0 & 3,0 \\
\hline Cetil ésteres & 3,0 & 3,0 & 3,0 & 3,0 & 3,0 & - \\
\hline $\begin{array}{l}\text { Triglicerídeos dos Ácidos Cáprico e } \\
\text { Caprílico }\end{array}$ & 2,0 & 2,0 & 2,0 & 2,0 & 2,0 & 2,0 \\
\hline $\begin{array}{l}\text { C10-40 } \\
\text { Isoalkylamidopropylethyldimonium } \\
\text { Ethosulfate (and) Dipropylene } \\
\text { Glycol }\end{array}$ & 3,0 & 3,0 & 3,0 & 3,0 & 3,0 & 3,0 \\
\hline Óleo de Abacate & 0,5 & 0,5 & 0,5 & 0,5 & 0,5 & 0,5 \\
\hline Óleo de Argan & 0,5 & 0,5 & 0,5 & 0,5 & 0,5 & 0,5 \\
\hline Óleo de Moringa & 0,5 & 0,5 & 0,5 & 0,5 & 0,5 & 0,5 \\
\hline BHT & 0,05 & 0,05 & 0,05 & 0,05 & 0,05 & 0,05 \\
\hline Fenoxietanol e parabenos & 0,8 & 0,8 & 0,8 & 0,8 & 0,8 & 0,8 \\
\hline \multicolumn{7}{|l|}{ Fase B } \\
\hline Cloreto de cetil trimetil amônio & 1,0 & 1,0 & 1,0 & 1,0 & 1,0 & 1,0 \\
\hline Propilenoglicol & 1,5 & 1,5 & 1,5 & 1,5 & 1,5 & 1,5 \\
\hline EDTA dissódico & 0,1 & 0,1 & 0,1 & 0,1 & 0,1 & 0,1 \\
\hline Água Deionizada & 71,55 & 71,55 & 71,55 & 71,55 & 72,55 & 75,55 \\
\hline \multicolumn{7}{|l|}{ Fase C } \\
\hline $\begin{array}{l}\text { Aqua - Glycerin - PEG-8 - PEG- } \\
\text { 8/SMDI Copolymer - Palmitoyl } \\
\text { Myristyl Serinate - Sodium } \\
\text { Polyacrylate }\end{array}$ & 2,0 & 2,0 & 2,0 & 2,0 & 2,0 & 2,0 \\
\hline Propilenoglicol & 2,0 & 2,0 & 2,0 & 2,0 & 2,0 & 2,0 \\
\hline \multicolumn{7}{|l|}{ Fase D } \\
\hline $\begin{array}{l}\text { Aqua (and) Hydrolyzed Vegetable } \\
\text { Protein }\end{array}$ & 0,5 & 0,5 & 0,5 & 0,5 & 0,5 & 0,5 \\
\hline \multicolumn{7}{|l|}{ Fase $\mathbf{E}$} \\
\hline $\begin{array}{l}\text { Amodimethicone (and) } \\
\text { Cetrimonium Chloride (and) } \\
\text { Trideceth-12 }\end{array}$ & 4,0 & 4,0 & 4,0 & 4,0 & 4,0 & 4,0 \\
\hline
\end{tabular}

Em uma segunda etapa do desenvolvimento, foi empregado o PPG-3 Benzyl Ether Ethylhexanoate como emoliente, substituindo os Triglicerídeos dos Ácidos Cáprico e Caprílico. Outra alteração realizada nessa segunda etapa do desenvolvimento, foi a substituição do silicone empregado, optando pelo Amodimethicone (and) C11-15 Pareth-7 (and) Laureth-9 (and) Glycerin (and) Trideceth-12. A quantidade de propilenoglicol utlizada 
também foi maior e adicionou-se parte de água como componente da Fase $\mathrm{C}$, com o objetivo de melhorar a dispersão da ceramida, facilitando sua incorporação, além de ajudar na etapa de resfriamento, uma vez que é adicionada em torno de $40^{\circ} \mathrm{C}$. Nessa etapa foram desenvolvidas quatro formulações de pré-tratamento, FPE9, FPE10, FPE11 e FPE12, e quatro formulações de pós-tratamento, FPO7, FPO8, FPO9, FPO10 (Tabela 5), com os novos componentes e variando a proporção de base autoemulsionante e agente de consistência. 
Tabela 5 - Composição das formulações de pré-tratamento e pós tratamento, contendo óleo de argan, abacate e moringa da segunda etapa de desenvolvimento.

\begin{tabular}{|c|c|c|c|c|c|c|c|c|}
\hline \multirow{2}{*}{ Componentes } & \multicolumn{6}{|c|}{ Composição \%(p/p) } & \multirow[b]{2}{*}{ FPO9 } & \multirow[b]{2}{*}{ FPO10 } \\
\hline & FPE9 & FPE10 & FPE11 & FPE12 & FPO7 & FPO8 & & \\
\hline \multicolumn{9}{|l|}{ Fase A } \\
\hline Álcool Cetoestearílico 30/70 & 3,0 & 2,0 & 4,0 & 3,0 & 3,0 & 3,0 & 4,0 & 2,0 \\
\hline $\begin{array}{l}\text { Behentrimonium Methosulfate } \\
\text { (and) Cetyl Alcohol (and) Butylene } \\
\text { Glycol }\end{array}$ & 3,0 & 4,0 & 3,0 & 4,0 & 3,0 & 4,0 & 3,0 & 5,0 \\
\hline $\begin{array}{l}\text { C1O-40 } \\
\text { Isoalkylamidopropylethyldimonium } \\
\text { Ethosulfate (and) Dipropylene } \\
\text { Glycol }\end{array}$ & - & - & - & - & 3,0 & 3,0 & 3,0 & 3,0 \\
\hline Cetil ésteres & 3,0 & 3,0 & 3,0 & 3,0 & 3,0 & - & 3,0 & 3,0 \\
\hline $\begin{array}{l}P P G-3 \text { Benzyl Ether } \\
\text { Ethylhexanoate }\end{array}$ & 3,0 & 3,0 & 3,0 & 3,0 & 3,0 & 3,0 & 3,0 & 3,0 \\
\hline Óleo de Abacate & 0,5 & 0,5 & 0,5 & 0,5 & 0,5 & 0,5 & 0,5 & 0,5 \\
\hline Óleo de Argan & 0,5 & 0,5 & 0,5 & 0,5 & 0,5 & 0,5 & 0,5 & 0,5 \\
\hline Óleo de Moringa & 0,5 & 0,5 & 0,5 & 0,5 & 0,5 & 0,5 & 0,5 & 0,5 \\
\hline ВHT & 0,05 & 0,05 & 0,05 & 0,05 & 0,05 & 0,05 & 0,05 & 0,05 \\
\hline Fenoxietanol e parabenos & 0,8 & 0,8 & 0,8 & 0,8 & 0,8 & 0,8 & 0,8 & 0,8 \\
\hline \multicolumn{9}{|l|}{ Fase B } \\
\hline Cloreto de cetil trimetil amônio & 1,0 & 1,0 & 1,0 & 1,0 & 1,0 & 1,0 & 1,0 & 1,0 \\
\hline Propilenoglicol & 2,0 & 2,0 & 2,0 & 2,0 & 2,0 & 2,0 & 2,0 & 2,0 \\
\hline EDTA dissódico & 0,1 & 0,1 & 0,1 & 0,1 & 0,1 & 0,1 & 0,1 & 0,1 \\
\hline Água Deionizada & 69,05 & 68,05 & 67,05 & 67,05 & 68,05 & 67,05 & 67,05 & 67,05 \\
\hline \multicolumn{9}{|l|}{ Fase C } \\
\hline $\begin{array}{l}\text { Aqua - Glycerin - PEG- } 8 \text { - PEG- } \\
\text { 8/SMDI Copolymer - Palmitoyl } \\
\text { Myristyl Serinate - Sodium } \\
\text { Polyacrylate }\end{array}$ & 2,0 & 2,0 & 2,0 & 2,0 & 2,0 & 2,0 & 2,0 & 2,0 \\
\hline Propilenoglicol & 2,0 & 2,0 & 2,0 & 2,0 & 2,0 & 2,0 & 2,0 & 2,0 \\
\hline Água Deionizada & 4,0 & 4,0 & 4,0 & 4,0 & 4,0 & 4,0 & 4,0 & 4,0 \\
\hline \multicolumn{9}{|l|}{ Fase D } \\
\hline $\begin{array}{l}\text { Aqua (and) Hydrolyzed Vegetable } \\
\text { Protein }\end{array}$ & 0,5 & 0,5 & 0,5 & 0,5 & 0,5 & 0,5 & 0,5 & 0,5 \\
\hline \multicolumn{9}{|l|}{ Fase $\mathbf{E}$} \\
\hline $\begin{array}{l}\text { Amodimethicone (and) C11-15 } \\
\text { Pareth-7 (and) Laureth-9 (and) } \\
\text { Glycerin (and) Trideceth-12 }\end{array}$ & 3,0 & 3,0 & 3,0 & 3,0 & 3,0 & 3,0 & 3,0 & 3,0 \\
\hline \multicolumn{9}{|l|}{ Fase $\mathbf{F}$} \\
\hline $\begin{array}{l}\text { Cinnamidopropyltrimonium } \\
\text { Chloride }\end{array}$ & 3,0 & 3,0 & 3,0 & 3,0 & - & - & - & - \\
\hline
\end{tabular}




\subsection{Testes de estabilidade}

\subsubsection{Centrifugação}

Este teste precede a avaliação preliminar da estabilidade. Para isso, 3 gramas de cada uma das formulações foram submetidos a três ciclos de centrifugação, a $3.000 \mathrm{rpm}$ (correspondente a $640 \mathrm{~g}$ ), por 30 minutos (BRASIL, 2004). A centrífuga utilizada foi Excelsa Baby II,modelo 206-R, potência 0,0440, Fanem. Após o final de cada ciclo, foi avaliada visualmente a presença de algum sinal de instabilidade das formulações.

\subsubsection{Estabilidade Preliminar}

A avaliação da estabilidade preliminar foi realizada a fim de observar alterações nas formulações por um período de 15 dias de estocagem em câmara climática à $45^{\circ} \mathrm{C}$, o que impossibilitaria o prosseguimento dos estudos. Para tanto, as formulações estáveis frente ao teste de centrifugação foram observadas diariamanete quanto às suas características organolépticas, como alterções na cor, odor e aspecto, além da avaliação diária dos valores de $\mathrm{pH}$.

\subsubsection{Determinação do $\mathrm{pH}$}

A determinação dos valores de $\mathrm{pH}$ foi realizada em peagômetro Digimed, modelo DM 20. As medidas foram realizadas em triplicata e, quando necessário, o ajuste do pH foi feito utilizando solução diluída de ácido cítrico a 10\%. Em uma primeira etapa, as formulações foram submetidas a análises diárias para verificação do valor do $\mathrm{pH}$, como parte da avaliação preliminar da estabilidade. Em relação às formulações que foram escolhidas para as etapas posteriores do projeto, novas avaliações semanais foram feitas, juntamente com o estudo reológico, por um período de 28 dias.

\subsection{Estabilidade Acelerada}

As formulações estáveis frente a avaliação preliminar de estabilidade foram submetidas a estudo de estabilidade acelerada. Nessa etapa, as formulações acondicionadas em embalagens plásticas, brancas e opacas, foram estocadas em diferentes condições de temperatura (temperatura ambiente, câmaras climáticas de 37 e $45^{\circ} \mathrm{C}$ e geladeira a $4^{\circ} \mathrm{C}$ ) por um período de 
90 dias. Em intervalos de 7 dias, as formulações foram analisadas quanto às caracterísiticas ornanolépticas. Além disso, ao final do período de 90 dias, as formulações foram novamente submetidas ao teste de centrifugação, sob as mesmas condições descritas no item 4.5.1.

\subsection{Protocolo de Tratamento das Mechas}

\subsubsection{Protocolo Inicial}

Na primeira etapa do projeto, que consistiu na aplicação de formulações contendo óleos vegetais em mechas submetidas ou não (controle) ao processo de alisamento químico, foram utilizadas mechas de $2 \mathrm{~g}$ e comprimento de $25 \mathrm{~cm}$, cabelo tipo castanho escuro extra cacheado, fornecidos pela empresa Andrea Lopes Cabelos ${ }^{\circledR}$. A segunda etapa do estudo, que consistiu na exposição de mechas de cabelo, com ou sem aplicação das formulações cosméticas desenvolvidas, em um simulador solar, foi realizada com mechas de cabelo fornecidas pela empresa De Meo Brothers Inc.

Todas as mechas empregadas neste estudo passaram por uma lavagem prévia com solução de Lauril Sulfato de Sódio $10 \%$ e secas naturalmente a $25 \pm 2{ }^{0} \mathrm{C}$ e UR $55 \pm 5 \%$.

\subsubsection{Aplicação das substâncias alisantes}

As mechas de cabelo foram submetidas ao processo de alisamento químico, segundo instruções do fabricante do produto, com o emprego de formulação comercial a base de Tioglicolato de Amônio. Para isso, as mechas foram divididas em dois grupos, pré-tratamento e pós-tratamento, e tratadas com 4 formulações diferentes (Figura 5). A escolha dos ativos foi baseada na frequência de uso dessas substâncias nos procedimentos de alisamentos legalmente permitidos no Brasil. 
Figura 5- Descrição dos tratamentos realizados nas mechas de cabelo submetidas às análises sensoriais.

\begin{tabular}{|cc|}
\hline \multicolumn{2}{|c|}{ ALISAMENTO À BASE DE TIOGLICOLATO DE AMÔNIO } \\
\hline Pré-tratamento & Pós- tratamento \\
\hline Creme contendo óleo de Abacate & Creme contendo óleo de Abacate \\
\hline Creme contendo óleo de Argan & Creme contendo óleo de Argan \\
\hline Creme contendo óleo de Moringa & Creme contendo óleo de Moringa \\
\hline Creme contendo associação dos 3 óleos & Creme contendo associação dos 3 óleos \\
\hline
\end{tabular}

\subsubsection{Descrição dos grupos de mechas}

\subsubsection{Pré-tratamento}

As mechas foram lavadas com solução de Lauril éter sulfato de sódio a 3\%, tratadas com $2 \mathrm{~g}$ de formulação, sendo massageadas por dois minutos na orientação raiz-pontas, com os dedos polegares, indicador e médio. Em seguida, as mechas foram deixadas em repouso por 3 minutos e, então, enxaguadas com água corrente morna $\left(40 \pm 2^{\circ} \mathrm{C}\right)$ por um minuto, garantindo a remoção completa de todos os resíduos. As mechas secaram naturalmente em ambiente com temperatura e umidade controladas de $25 \pm 2^{\circ} \mathrm{C}$ e UR $55 \pm 5 \%$, respectivamente. Esse procedimento foi repetido por 5 dias consecutivos. As mechas foram, então, submetidas ao alisamento químico e, de acordo com a formulação empregada na etapa de pré-tratamento, separadas em grupos, como descrito a seguir:

Grupo A1: creme de tratamento capilar contendo óleo de moringa.

Grupo A2: creme de tratamento capilar contendo óleo de abacate.

Grupo A3: creme de tratamento capilar contendo óleo de argan.

Grupo A4: creme capilar contendo associação dos 3 óleos.

\subsubsection{Pós-tratamento}

As mechas foram submetidas ao alisamento químico, lavadas com solução de Lauril éter sulfato de sódio $3 \%$ e, então, tratadas com $2 \mathrm{~g}$ de formulação, sendo massageadas por dois minutos na orientação raiz-pontas, com os dedos polegares, indicador e médio. Em seguida, as 
mechas foram deixadas em repouso por 3 minutos e, então, enxaguadas com água corrente morna $\left(40 \pm 2^{\circ} \mathrm{C}\right)$ por um minuto, garantindo a remoção completa de todos os resíduos. As mechas secaram naturalmente em ambiente com temperatura e umidade controladas. Esse procedimento foi repetido por 5 dias consecutivos. De acordo com a formulação empregada na etapa de pós-tratamento, as mechas foram separadas em grupos, como descrito a seguir:

Grupo B1: creme de tratamento capilar contendo óleo de moringa.

Grupo B2: creme de tratamento capilar contendo associação dos 3 óleos.

Grupo B3: creme de tratamento capilar contendo óleo de argan.

Grupo B4: creme de tratamento capilar contendo óleo de abacate.

\subsection{Seleção das formulações finais}

Para a escolha das formulações mais adequadas para serem utilizadas nas etapas posteriores do projeto, optou-se por utilizar a análise sensorial em mechas de cabelo, como medida subjetiva, associada a uma medida objetiva de avaliação da força máxima necessária para romper a fibra capilar.

\subsubsection{Análise Sensorial em mechas de cabelo}

Nesta etapa, foram empregadas as 4 formulações desenvolvidas contendo os seguintes óleos vegetais: óleo de abacate, argan e moringa, sendo que três formulações continham um óleo vegetal isolado e a quarta a associação de todos. O objetivo foi avaliar se a associação dos óleos teria um efeito melhor do que o emprego do óleo isolado e se diferenças nos parâmetros avaliados seriam perceptíveis pelas painelistas.

\subsubsection{Protocolo Análise Sensorial}

Para a realização da avaliação sensorial, foram selecionadas 40 painelistas não treinadas, mas que se encaixavam no critério de potenciais consumidores para as formulações avaliadas.

Todas as participantes do estudo avaliaram todos os grupos. Foi feito um teste de comparação pareado, no qual cada painelista recebia 2 mechas diferentes e era orientada a passar os dedos, por todo o comprimento dos cabelos, no sentido raiz-pontas, por até 5 vezes. Em seguida, foram atribuídas notas comparativas, em uma escala de 0 a 10, para cada uma 
das mechas, em 2 parâmetros diferentes: sedosidade e brilho. Sendo assim, cada participante preencheu a ficha de avaliação para as mechas da etapa de pré-tratamento, com 6 avaliações, e uma ficha separada para a etapa de pós-tratamento, também com 6 avaliações. A ordem da avaliação das mechas foi randomizada entre as participantes do estudo.

\subsubsection{Avaliação das Propriedades Mecânicas}

Nesta primeira etapa do projeto, a avaliação das propriedades mecânicas foi realizada no Laboratório Integrado de Pesquisa em Biocompatibilidade de Materiais da Faculdade de Odontologia de Ribeirão Preto - USP, utilizando a máquina universal para ensaios mecânicos, modelo DL 2000, do fabricante EMIC, dotado de célula de carga com capacidade de 10 kgf.

Para a realização dos testes foram avaliados 60 fios de cabelo de cada um dos 14 grupos objeto de estudo, agrupados em 42 amostras (corpo de prova). O corpo de prova foi preparado com 20 fios cada, fixados com cola quente, com comprimento de $25 \mathrm{~cm}$, tipo de cabelo extra cacheado, fornecidos pela empresa Andrea Lopes Cabelos ${ }^{\circledR}$.

Para certificar que as amostras foram preparadas de forma eficaz, foram realizados testes preliminares para garantir que a ruptura do fio ocorreria na região intermediária entre os pontos de fixação e não na região que foi fixada com a cola quente.

A célula de carga foi pré-carregada e a taxa de velocidade de tração foi de $10 \mathrm{~mm} / \mathrm{min}$. Os testes foram realizados em ambiente com temperatura a $22 \pm 2{ }^{\circ} \mathrm{C}$ e umidade a $55 \pm 5 \%$. Para a realização do estudo foi utilizada uma garra com aperto simples e prendimento por mordentes lisos e caracol atenuador de tensões geométricas.

\subsubsection{Descrição dos grupos de mechas}

Grupo 1: composto por 3 mechas, que receberam processo de alisamento térmico (secador e piastra), seguido de lavagem com shampoo.

Grupo 2: composto por 3 mechas com alisamento químico (creme alisante à base de Hidróxido de Guanidina) que receberam pré-tratamento com a formulação contendo óleo de abacate.

Grupo 3: composto por 3 mechas com alisamento químico (creme alisante à base de Hidróxido de Guanidina) que receberam pré-tratamento com a formulação contendo óleo de argan. 
Grupo 4: composto por 3 mechas com alisamento químico (creme alisante à base de Hidróxido de Guanidina) que receberam pré-tratamento com a formulação contendo óleo de moringa.

Grupo 5: composto por 3 mechas com alisamento químico (creme alisante à base de Tioglicolato de Amônio), que receberam pré-tratamento com a formulação contendo óleo de moringa.

Grupo 6: composto por 3 mechas com alisamento químico (creme alisante à base de Tioglicolato de Amônio), que receberam pré-tratamento com a formulação contendo óleo de abacate.

Grupo 7: composto por 3 mechas com alisamento químico (creme alisante à base de Tioglicolato de Amônio), que receberam pré-tratamento com a formulação contendo óleo de argan.

Grupo 8: composto por 3 mechas com alisamento químico (creme alisante à base de Tioglicolato de Amônio), que receberam pré-tratamento com a formulação contendo associação dos 3 óleos.

Grupo 9: composto por 3 mechas com alisamento químico (creme alisante à base de Tioglicolato de Amônio), que receberam pós-tratamento com a formulação contendo óleo de moringa.

Grupo 10: composto por 3 mechas com alisamento químico (creme alisante à base de Tioglicolato de Amônio), que receberam pós-tratamento com a formulação contendo a associação dos 3 óleos.

Grupo 11: composto por 3 mechas com alisamento químico (creme alisante à base de Tioglicolato de Amônio), que receberam pós-tratamento com a formulação contendo óleo de argan.

Grupo 12: composto por 3 mechas com alisamento químico (creme alisante à base de Tioglicolato de Amônio), que receberam pós-tratamento com a formulação contendo óleo de abacate.

Grupo 13: composto por 3 mechas com alisamento químico com o creme alisante à base de Tioglicolato de Amônio.

Grupo 14: composto por 3 mechas com alisamento químico com o creme alisante à base de Hidróxido de Guanidina. 
As mechas do grupo controle passaram pelo tratamento térmico (secador e piastra), uma vez que este tratamento faz parte da etapa de finalização dos dois processos de alisamento químico realizados nas demais mechas.

\subsection{Avaliação da Estabilidade das Formulações}

A escolha das formulações avaliadas nesta etapa foi feita baseada nos resultados das análises anteriores. Dessa forma, a formulação de pré-tratamento selecionada foi a que, após aplicada nas mechas de cabelo, forneceu os melhores resultados no teste de resistência a ruptura e melhores notas na análise sensorial. Da mesma forma, a formulação de póstratamento foi selecionada.

\subsubsection{Reologia}

Para a realização do estudo do comportamento reológico, cada uma das formulações foi novamente elaborada e acondicionada em 4 embalagens plásticas opacas, as quais foram mantidas por 24 horas em temperatura ambiente $25 \pm 5^{\circ} \mathrm{C}$ antes da primeira análise. Após as 24 horas, foi realizada a primeira análise (denominada T0) e, em seguida, as formulações foram armazenadas no ambiente $25 \pm 5^{\circ} \mathrm{C}$, na geladeira, $4 \pm 1^{\circ} \mathrm{C}$ (Eletrolux) e em estufas termostatizadas à $37 \pm 1^{\circ} \mathrm{C}$ e $45 \pm 1^{\circ} \mathrm{C}$ (Eletrolab, modelo III FC com controle de umidade, $70 \%$ de umidade relativa) para a avaliação da estabilidade física frente ao estresse térmico . As demais análises no reômetro foram realizadas em intervalos de 7 dias, durante 28 dias, sendo que 24 horas antes das medidas, as formulações eram retiradas das estufas e da geladeira e mantidas na temperatura ambiente $25 \pm 5^{\circ} \mathrm{C}$ juntamente com àquelas que já se encontravam nesta temperatura. Foi utilizado o reômetro rotacional DV-III (Cone/ Placa) Brookfield, com spindle CP52, acoplado ao software Rheocalc versão V1.01.

Para a obtenção da curva ascendente, utilizou-se velocidades de rotação progressivamente maiores (0,1-30,1 rpm), e para a curva descendente, o procedimento foi repetido no sentido inverso, ou seja, velocidades de rotação progressivamente menores (30,1-0,1 rpm). As medidas foram realizadas em triplicatas e efetuadas a $25 \pm 1^{\circ} \mathrm{C}$ (MOSER; CORNELIO; NICOLETTI TELIS, 2013).

Nos estudos do comportamento reológico, foram avaliadas formulações com diferentes proporções de base autoemulsionante e agente de consistência, a fim de verificar 
qual concentração forneceria resultados melhores para o objetivo proposto. Os gráficos foram feitos no software OriginPro 8.

\subsubsection{Avaliação do pH}

O procedimento é o mesmo descrito no item 4.5.3. Entretanto, nessa etapa somente as formulações com os melhores desempenhos nas etapas anteriores foram avaliadas, juntamente com o estudo reológico, semanalmente, por um período de 28 dias.

\subsection{Avaliação das mechas de cabelo expostas à radiação solar}

Nesta etapa do projeto, foram empregadas mechas de cabelo virgens do tipo extra curly, fornecidas pela empresa De Meo Brothers Inc. (New York, USA).

As formulações de pré e pós-tratamento finais foram escolhidas após realização dos testes descritos anteriormente. Dessa forma, as formulações foram aplicadas nas mechas empregadas e submetidas a avaliações de forma a verificar proteção ou reparação dos danos induzidos pela radiação solar.

\subsubsection{Tratamento das mechas}

Todas as mechas empregadas nessa etapa passaram pela lavagem inicial descrita no item 4.7.1.

De forma similar à realizada com as mechas que passaram pelo processo de alisamento químico, também nessa etapa as mechas foram divididas em grupos de pré e pós-tratamento. Dessa forma, todas as mechas que compunham o grupo de pré-tratamento foram tratadas diariamente, durante 5 dias, com $2 \mathrm{~g}$ de formulação, sendo massageadas por 2 minutos. Em seguida, foram deixadas em repouso por 20 minutos (DRAELOS, 2013) e enxaguadas em água corrente a $40 \pm 2^{\circ} \mathrm{C}$, durante 1 minuto, de forma que toda a formulação fosse retirada. $\mathrm{O}$ mesmo foi feito para o grupo de pós-tratamento.

Nesta etapa do projeto foram utilizadas 24 mechas, que foram dividas em 8 diferentes grupos (Figura 6). Cada grupo era constituído por 3 mechas, de forma que os tratamentos foram realizados em triplicata. 
Figura 6- Distribuição das mechas de cabelo nos grupos de tratamento.

\begin{tabular}{|c|c|c|c|}
\hline Grupo Controle & Controle Negativo & $\begin{array}{l}\text { Grupo Pré- } \\
\text { Tratamento }\end{array}$ & $\begin{array}{l}\text { Grupo Pós- } \\
\text { Tratamento }\end{array}$ \\
\hline $\begin{array}{l}\text { CV- Mechas de cabelo } \\
\text { virgem. }\end{array}$ & $\begin{array}{l}\text { CI- Mechas de cabelo } \\
\text { exposta ao simulador } \\
\text { solar, sem passar por } \\
\text { nenhum tratamento. }\end{array}$ & $\begin{array}{l}\text { VPE- Mechas expostas } \\
\text { ao simulador solar, que } \\
\text { passaram pelo pré- } \\
\text { tratamento com a } \\
\text { formulação veículo } \\
\text { (sem adição do filtro } \\
\text { solar e dos óleos } \\
\text { vegetais). } \\
\text { VPEF- Mechas } \\
\text { expostas ao simulador } \\
\text { solar, que passaram } \\
\text { pelo pré-tratamento } \\
\text { com a formulação } \\
\text { veículo acrescida do } \\
\text { filttro solar. } \\
\text { VPEO- Mechas } \\
\text { expostas ao simulador } \\
\text { solar, que passaram } \\
\text { pelo pré-tratamento } \\
\text { com a formulação } \\
\text { veículo acrescida dos } \\
\text { óleos vegetais. } \\
\text { VPEOF- Mechas } \\
\text { expostas ao simulador } \\
\text { solar, que passaram } \\
\text { pelo pré-tratamento } \\
\text { com a formulação } \\
\text { veículo acrescida do } \\
\text { filtro solar e dos óleos } \\
\text { vegetais. }\end{array}$ & $\begin{array}{l}\text { VPO- Mechas expostas ao } \\
\text { simulador solar, que } \\
\text { passaram pelo pós- } \\
\text { tratamento com a } \\
\text { formulação veículo (sem } \\
\text { adição dos óleos vegetais). } \\
\text { VPOO- Mechas expostas } \\
\text { ao simulador solar, que } \\
\text { passaram pelo pós- } \\
\text { tratamento com a } \\
\text { formulação veículo } \\
\text { acrescida dos óleos } \\
\text { vegetais. }\end{array}$ \\
\hline
\end{tabular}

\subsubsection{Exposição das mechas à radiação solar}

Nesta etapa as mechas de todos os grupos, com exceção do grupo controle composto pelas mechas de cabelo virgem, foram expostas em uma câmara para testes Xenon Q-SUN Xe-3 (Q-Lab), que é um Simulador Solar. As mechas foram expostas em condições que simulam o espectro total do sol. A irradiância a $340 \mathrm{~nm}$ foi de $0,35 \mathrm{~W} / \mathrm{m}^{2}$. As mechas foram distribuídas na plataforma interna do equipamento e viradas diariamente de forma a assegurar a homogeneidade do processo de radiação pelas lâmpadas de arco xenônio e mantidas no equipamento por 144h (CHANDRASHEKARA; RANGANATHAIAH, 2010; HABE et al., 2011; LONGO et al., 2013; RATNAPANDIAN; WARNER; KAMATH, 1998) 
Ao fim do período de exposição à radiação solar, as mechas foram retiradas do equipamento e seguiram para as etapas posteriores. Cabe salientar que as mechas constituintes do grupo de pré-tratamento passaram pela etapa de aplicação das formulações durante os 5 dias que precederam a exposição das mechas ao Simulador Solar. Em relação às mechas constituintes do grupo de pós-tratamento, a aplicação das formulações foi realizada por 5 dias consecutivos após a retirada das mechas do equipamento.

\subsubsection{Avaliação das propriedades mecânicas da fibra capilar}

Nesta etapa do projeto, optou-se pela realização da avaliação da tração à ruptura do fio de cabelo, empregando o Texturômetro Analyser ${ }^{\circledR}$ modelo TAXT2. A velocidade de tração das garras foi de $300 \mathrm{~mm} / \mathrm{min}$, com distância para teste de $40,0 \mathrm{~mm}$, célula de carga de $50 \mathrm{Kg}$ e sensibilidade de $0,49 \mathrm{~N}$. As fibras de cabelo, com $5 \mathrm{~cm}$ de comprimento, foram presas individualmente em garras localizadas na parte superior e inferior do equipamento e, então, submetidas ao teste. As fibras foram tracionadas e foi medida a força máxima, em Newton $(\mathrm{N})$, necessária para a ruptura do fio.

Cada grupo, conforme descrito na Figura 6, composto por 3 mechas que passaram pelo mesmo tratamento, foi avaliado após seleção da amostra de fios de cabelo. Assim, foram separados 20 fios com diâmetro semelhante. Para isso, foram feitas medidas do diâmetro de cada fio de cabelo em três regiões distintas: 3, 10 e $17 \mathrm{~cm}$ de distância do limite superior da mecha, utilizando um Micômetro Digital Mitutoyo. Foi calculada a média desses 3 valores e escolhidos 20 fios com valores semelhantes, com variação menor que $0,10 \mathrm{~mm}$. Isso foi realizado para cada uma das 3 mechas que compunham cada grupo, de forma que ao final foram analisados no texturômetro 60 fios por tratamento.

Essa análise foi feita no tempo 0 (T0), que corresponde às mechas antes de passarem por qualquer tratamento, e no tempo 144 (T144), que corresponde às mechas, submetidas aos diferentes tratamentos, após 144 horas de exposição no simulador solar. Dessa forma, cada mecha serviu como seu próprio controle, de forma a gerar resultados mais confiáveis, considerando a grande variabilidade de resultados dos fios virgens de mechas diferentes.

Os resultados obtidos nesse experimento foram tratados estatisticamente utilizando o teste Two way ANOVA no software GraphPad Prisma 5.0, comparando os valores obtidos no T0 e T144 para cada grupo de mechas. 


\subsubsection{Avaliação da variação de cor das mechas de cabelo}

O sistema CIE (Comissão Internacional de Iluminação) é utilizado para descrever a cor. Em 1976 a CIE definiu o espaço CIELAB que representa as cores básicas em três unidades e que são descritas por luminosidade $\left(\mathrm{L}^{*}\right)$, coordenada $\mathrm{a}^{*}$ (eixo do vermelho a verde) e coordenada b* (conteúdo de amarelo a azul) (RAMO et al., 2002). O sistema CIE (Comissão Internacional de Iluminação) é utilizado para descrever a cor. Em 1976 a CIE definiu o espaço CIELAB que representa as cores básicas em três unidades e que são descritas por luminosidade $\left(\mathrm{L}^{*}\right)$, coordenada $\mathrm{a}^{*}$ (eixo do vermelho a verde) e coordenada $\mathrm{b}^{*}$ (conteúdo de amarelo a azul) (Ramo et al., 2002). Está baseado na percepção das cores pelo sistema visual humano. Existem disponíveis equipamentos de medição da cor capazes de fornecer coordenadas colorimétricas $\left(\mathrm{L}^{*} \mathrm{a} \mathrm{b}^{*}\right)$ universais sob iluminantes e observador padronizados.

O colorímetro e o espectrofotômetro são dois tipos de instrumentos empregados na determinação colorimétrica. O colorímetro utiliza filtros que simulam a resposta dos cones do olho humano, gerando resultados numéricos. Já o espectrofotômetro de refletância fornece a curva de distribuição de reflectância da amostra, em cada comprimento de onda da faixa de medição do instrumento. O seu mecanismo de funcionamento é composto por um feixe de luz policromático que ilumina a amostra de forma difusa, espalhada. A amostra é capaz de refletir parte deste feixe, que seguirá para o prisma ou para uma grade de difração. Os componentes monocromáticos, resultantes da difração, atinge os detectores espectrais especializados em cada faixa de comprimento de onda, que enviam para o processador o sinal correspondente à energia relativa recebida e o fator de reflectância. Os dados são apresentados em forma de gráfico. Existe um grande potencial do método espectrofotométrico de reflectância, sendo que são os equipamentos apontados como mais exatos, práticos e acessíveis (SILVA, 2004). Além disso, são os mais frequentemente citados na literatura para análises de cor em fios de cabelo (NOGUEIRA et al., 2007; SANTOS NOGUEIRA; JOEKES, 2004).

\subsubsection{Skin Colorimeter ${ }^{\circledR}$}

Um dos equipamentos empregados neste estudo foi o Skin Colorimeter ${ }^{\circledR}$. Seu princípio de funcionamento baseia-se numa sonda que envia uma luz branca LED. A luz emitida é dispersa uniformemente e outra parte é reletida e medida na sonda. Dentro da sonda existe uma matriz de cores especiais de modo a adaptar os valores obtidos da medição com valores padrões (Courage-KhazakaScientific-Devices, 2013). Assim, o parâmetro L* expressa o 
brilho da cor ou luminância, e está compreendido entre o valor de 100, para o branco total, e de 0 , para o preto total; o parâmetro a* representa alterações ao longo de um eixo, que muda de +60 , para o vermelho, a -60 , para o verde; e o parâmetro b* representa as mudanças de um valor de +60 , para o amarelo, a -60 , para o azul (Clarys et al., 2000).

Para a obtenção dos valores da escala colorimétrica das diferentes mechas, foram realizadas 12 medidas, sendo 6 na parte posterior e 6 na parte anterior de cada mecha. Para as análises comparativas, foram utlizadas as médias desses valores. A área de medida era macroscopicamente totalmente coberta pelos fios de cabelo.

\subsubsection{Chromameter ${ }^{\circledR}$ CR-400}

O segundo equipamento empregado neste estudo, a fim de obter valores comparativos dos mesmos parâmetros $\left(\mathrm{L}^{*} \mathrm{a}^{*} \mathrm{~b}^{*}\right.$ ), foi o Chromameter ${ }^{\circledR}$ CR-400 (Konica Minolta Sensing). Ao contrário do Skin Colorimeter ${ }^{\circledR}$, foi encontrado descrito em literatura o uso deste equipamento para obtenção da cor em mechas de cabelo (FUKUHARA; NOJIRI, 2011; GERRARD, 1989; NAYSMITH et al., 2004). O procedimento utilizado para a obtenção dos valores foi similar ao descrito para o Skin Colorimeter ${ }^{\circledR}$. Em ambos os casos foram calculados os valores de $\mathrm{DL}^{*}, \mathrm{Da}^{*}$ e $\mathrm{Db}^{*}$, que é a diferença entre os valores obtidos para a mecha de cabelo analisado e a mecha de cabelo virgem padrão. Nesse estudo, cada mecha serviu como seu próprio controle. Para isso, foram realizadas medidas em todas as mechas, antes de passarem por algum tratamento, e novas medidas após passarem pelos tratamento descritos na Figura 6. Optou-se por essa metodologia pois, apesar de serem mechas padronizadas, a variação dos valores obtidos entre elas era grande, podendo comprometer os resultados finais. Sendo cada mecha o seu próprio controle, visou-se obter valores mais confiáveis.

\subsubsection{Microscopia Eletrônica de Varredura}

É um método muito utilizado para a avaliação capilar, permitindo a avaliação estrutural e química da fibra com imagens de alta definição com ampliação de até 300.000 vezes. Com este método pode-se avaliar: a aparência geral da fibra capilar, deposição de partículas sobre o fio de cabelo e alterações morfológicas e estruturais (TOMES et al., 2007; VELASCO et al., 2009), permitindo avaliar alterações provocadas na fibra capilar com o envelhecimento. 
Amostras de cabelos virgens, irradiados sem tratamento cosmético e irradiados após pré ou pós-tratamento com as formulações desenvolvidas, foram colocados em porta amostras específico (stubs) utilizando fita adesiva de cobre. Em seguida os porta-amostras foram recobertos com um filme de ouro pelo processo de pulverização anódica (sputtering), e analisados em microscópio eletrônico de varredura.

\subsubsection{Decomposição do triptofano}

Os aminoácidos do cabelo mais sensíveis à foto-oxidação são o triptofano, a cistina, a tirosina e a histidina (NOGUEIRA et al., 2004; ROBBINS, 2012). Sendo assim, a determinação da decomposição do triptofano é comumente realizada de modo a avaliar a extensão do dano causado após exposição das mechas de cabelo à radiação solar (NOGUEIRA; DICELIO; JOEKES, 2006; PANDE; JACHOWICZ, 1993). Dessa forma, os grupos de mechas foram analisados, dissolvendo $50 \mathrm{mg}$ de cabelo irradiado ou não-irradiado em $50 \mathrm{~mL}$ de Solução $\mathrm{NaOH}$ 2M. A solução foi deixada em repouso por 24 horas em temperatura ambiente, sem agitação. Em seguida, a solução foi filtrada e submetida aos experimentos de fluorescência. O espectro de fluorescência foi obtido em um Fluorímetro Fluorescence Spectrophotometer, modelo F-4500 (Hitachi), usando uma cubeta de quartzo de 1 cm. Os comprimentos de onda de excitação e emissão foram 290nm e 345nm, respectivamente. A intensidade de fluorescência das amostras foram medidas em unidades arbitrárias, que são proporcionais à concentração de triptofano em cada amostra de cabelo (FERNÁNDEZ et al., 2012a, 2012b; NOGUEIRA; DICELIO; JOEKES, 2006). 
5. Resultados e Discussão 


\subsection{Desenvolvimento de Formulações}

\subsubsection{Formulações capilares}

Foram desenvolvidas formulações do tipo emulsões O/A, classificadas como máscaras de tratamento intensivo que, embora similares aos condicionadores de uso diário após o shampoo, não são indicadas para uso com essa frequência. Ao contrário, seu uso deve ser feito para um tratamento intensivo, usualmente 1 vez por semana ou a cada 15 dias. A razão dessa diferenciação encontra-se na constituição dessas máscaras que possuem uma maior proporção de ingredientes ativos, capazes de permanecerem na fibra por um período maior após o enxágue. Além disso, são formulações com maior viscosidade, uma vez que essa característica é associada pelos consumidores com a percepção de um condicionamento mais eficaz dos cabelos (REICH et al., 2009). Outra característica dessas formulações é o tempo de permanência nos cabelos antes do enxágue, que é maior quando comparado aos condicionadores comuns. Usualmente intervalos de 20-30 minutos são indicados para permitir um tempo de contato suficiente para que os ativos tenham ação e recubram a superfície capilar adequadamente (DRAELOS, 2013).

Os produtos cosméticos são desenvolvidos de forma a restaurar a maleabilidade do cabelo, ao diminuir a eletricidade estática e reduzir a fricção entre os fios; devolver a maciez e recondicionar a fibra danificada, que é mais porosa e hidrofílica (BOLDUC; SHAPIRO, 2001). Entretanto, o desenvolvimento racional, baseado na seleção adequada de ativos e escolha das formulações baseada em resultados, é essencial para que produtos de qualidade cheguem ao mercado, protegendo os consumidores de danos capilares que impactam diretamente no bem-estar e autoestima.

Para este estudo foram selecionados três óleos vegetais, a saber: abacate, argan e moringa, como ativos para incorporação nas formulações desenvolvidas. Além disso, na etapa de pré-tratamento foi adicionado um filtro solar para os cabelos. Cada óleo possui uma constituição lipídica diferente e propriedades distintas e complementares como agentes hidratantes, emolientes e antioxidantes. Com isso, buscou-se manter ou recuperar as características de um cabelo saudável, mesmo quando submetido a tratamentos químicos e radiação solar.

A ideia inicial proposta para as formulações foi o desenvolvimento de um creme de prétratamento e pós-tratamento com enxágue (rinse off) e uma formulação sem enxágue (leave on). Entretanto, após pesquisa mais aprofundada sobre as análises que seriam empregadas no 
estudo, foi visto que as formulações sem enxágue não eram adequadas à proposta. Isso se deve à um motivo principal: a presença da formulação cosmética no fio de cabelo comprometeria a avaliação no Miscroscópio Eletrônico de Varredura (MEV), uma vez que a mecha permanece úmida com a presença da formulação, mesmo que aparentemente esteja seca, dificultando a deposição das partículas de ouro na amostra, etapa essa essencial para a boa qualidade das imagens obtidas no MEV.

Considerando todas essas características, foram desenvolvidas emulsões O/A com viscosidade elevada, com enxágue e tempo indicado de permanênia nos cabelos de 20 minutos.

Embora resultados mais promissores para as formulações contendo filtro solar fossem esperados com o uso de formulações sem enxágue, visto que o produto se manteria no cabelo por mais tempo e em maior concentração, também com a formulação com enxágue desenvolvida, o efeito protetor do filtro solar foi observado. A principal razão foi a escolha de um filtro com alta substantividade ao cabelo, mesmo após o enxágue do mesmo.

\subsubsection{Etapas do desenvolvimento}

O desenvolvimento das formulações empregadas neste estudo foi realizado em diferentes etapas. Primeiramente foi feita uma busca em literatura científica para escolha dos óleos vegetais que seriam empregados e quais as faixas de uso recomendadas. Em seguida, buscouse matérias-primas que tivessem efeito positivo no aumento da resistência dos fios, da sedosidade e brilho.

Em seguida, a busca foi pelo sistema emulsionante, capaz de gerar formulações estáveis. Também foi avaliado a compatibilidade entre os componentes, visto que as formulações possuem ingredientes com caráter catiônico, o que pode gerar instabilidade química, resultando em separação de fases da emulsão.

Na primeira etapa de desenvolvimento (FPE1-8) e (FPO 1-6), a rotação empregada na etapa de agitação foi de $600 \mathrm{rpm}$. Na segunda etapa do desenvolvimento (FPE9-12) e (FPO710), a rotação empregada na etapa de agitação foi de $300 \mathrm{rpm}$. Essa alteração foi realizada, uma vez que houve formação de espuma nas primeiras formulações, o que foi corrigido com a diminuição da velocidade de agitação. Sabe-se que a velocidade de agitação possui grande interferência na estabilidade das formulações, em sua consistência e no tamanho das gotículas de fase interna (MORAIS; OLIVEIRA; ROCHA-FILHO, 2014). 
Os ingredientes ativos presentes nas formulações desenvolvidas, a saber, óleo de abacate, óleo de argan, óleo de moringa foram selecionados baseado em suas características potenciais para o tratamento e reparação de cabelos danificados pela radiação solar ou tratamentos químicos. Além disso, o filtro solar utilizado na etapa de pré-tratamento foi escolhido de forma a reduzir a intensidade de radiação solar absorvida pelos cabelos.

Misturas de óleos vegetais tem surgido como um método econômico de alterar características físico-químicas dos óleos, além de aumentar a estabilidade oxidativa. Mistura adequada de óleos com grandes proporções de ácido oleico e linoleico pode resultar em misturas com características de estabilidade adequadas (ANWAR et al., 2007; MARIOD; EICHNER; HUSSEIN, 2005). Por essa razão optou-se pela associação de óleos vegetais diferentes, visto que a diferença em suas composições, levam a efeitos sinérgicos para o tratamento das fibras e também para o aumento da estabilidade das formulações.

Sabe-se que o ácido oleico é o ácido graxo monoinsaturado mais abundante na maioria dos óleos comuns (ANWAR et al., 2007; GUNSTONE, 2002). Quando comparado com ácidos graxos poli-insaturados, o ácido oleico é mais estável à oxidação tanto à temperatura ambiente quanto a temperaturas elevadas. Portanto, óleos com grandes quantidades de ácido oleico são mais estáveis ao processo de rancidificação. Os três óleos selecionados para esse estudo possuem como principal constituinte o ácido oleico. Além disso, o o óleo de moringa destaca-se devido a sua grande estabilidade, sendo apontado como um dos óleos vegetais mais estáveis disponíveis. Isso se deve ao seu menor número de poli-insaturações, que aumenta a sua estabilidade oxidativa (KLEIMAN; ASHLEY; BROWN, 2008).

Além dos óleos vegetais, foi adicionado um agente condicionante contendo 18-MEA (C10-40 Isoalkylamidopropylethyldimonium Ethosulfate (and) Dipropylene Glycol) para as formulações da etapa de pós-tratamento. Como já descrito, esse ácido graxo é um dos principais componentes lipídicos do cabelo e possui importante função na manutenção da hidrofobicidade da fibra e da suavidade ao toque. Foi demonstrado que tanto tratamentos químicos, quanto radiação ultravioleta são capazes de remover significativamente o 18-MEA presente na superfície do fio de cabelo, principalmente quando ligado via ligação tioéster (HABE et al., 2011; LEE, 2011; OKAMOTO et al., 2012). Por essa razão o objetivo foi buscar repor uma fração dessa camada natural de revestimento que é perdida quando os cabelos são expostos a diferentes danos.

Ainda em relação aos constituintes das emulsões desenvolvidas, foi feita uma ampla pesquisa dos demais ingredientes selecionados para a composição das formulações cosméticas 
desenvolvidas. Dessa forma, buscou-se ingredientes que estivessem de acordo com a proposta e aplicação do estudo, conforme jusificado a seguir.

1. Cetearyl Alcohol and Dicetyl Phosphate and Ceteth-10 Phosphate (Crodafos $\mathrm{CES}^{\circledR}$ ): o objetivo da escolha foi para a utilização nas formulações de pré-tratamemto, que possuem filtros solares em sua composição, visto que, segundo fabricante, é atribuído ao Crodafos $\mathrm{CES}^{\circledR}$ um bom desempenho com esse tipo de produto, chegando até ao aumento do fator de proteção solar.

\section{Behentrimonium Methosulfate (and) Cetyl Alcohol (and) Butylene Glycol (Incroquat}

Behenyl TMS 50): como um dos objetivos do estudo foi a reparação de cabelos submetidos a danos químicos e radiação solar, essa característica foi considerada para a escolha dessa matéria-prima, ou seja, cabelo e couro cabeludo já danificados não devem ser tratados com formulações com maior potencial de causar irritação. Além disso, é atribuída a essa cera autoemulsionante, a capacidade de formar formulações estáveis com a capacidade de serem substantivas à fibra capilar, melhorando a penteabilidade do cabelo, tanto úmido quanto seco.

3. PPG-3 Benzyl Ether Ethylhexanoate, $\left(\right.$ Crodamol SFX $\left.{ }^{\circledR}\right)$ : Escolhido devido ao alto índice de refração, que leva a um aumento de brilho nos fios de cabelo. Isso ocorre devido a formação de um filme na superfície, possibilitando um melhor alinhamento da fibra capilar e diminuindo o ângulo entre as células da cutícula. É informado, segundo fabricante, que o uso dessa matéria-prima oferece benefícios sensoriais, com boa espalhabilidade e efeito não pegajoso.

4. Caprylic/Capric Triglyceride: Foi escolhido devido a compatibilidade com óleos vegetais, silicones e ésteres sintéticos e boa capacidade como diluente e ativos.

5. Aqua (and) Hydrolyzed Vegetable Protein - PG-Propyl Silanetriol (Keravis ${ }^{\circledR}$ ): Foi selecionado devido caractrísticas disponibilizadas em seu informe técnico que demonstram que as mechas tratadas com Keravis ${ }^{\circledR}$ levaram a resultados melhores em todas as avaliações da resistência do fio à ruptura, quando comparadas às mechas tratadas com D-panthenol, ativo amplamente utilizado em formulações cosméticas. Além disso, em uma análise sensorial conduzida com a presença ou não do Keravis ${ }^{\circledR}$, na qual as painelistas tinham que escolher qual mecha parecia mais saudável e resistente após um ciclo de lavagens e de 1000 ciclos de penteabilidade, $91 \%$ das participantes escolheram as mechas tratadas com Keravis ${ }^{\circledR}$.

6. Cinnamidopropyltrimonium Chloride (Crodasorb ${ }^{\circledR}$ UV-283): Escolhido pois, além da capacidade de proteger os cabelos contra radiação UVB, é necessário que o produto seja substantivo ao cabelo. No caso do presente estudo, as formulações desenvolvidas são com 
enxágue e, em testes conduzidos pelo fabricante, o Crodasorb ${ }^{\circledR}$ UV-283 mostrou ser substantivo ao cabelo mesmo após enxágue e com melhores resultados em estudos comparativos com outros filtros solares amplamente utilizados.

7. Cetrimonium Chloride: Classificado como um tensoativo catiônico sob a forma de compostos quaternários de amônio, é um dos agentes condicionantes mais comuns em produtos comerciais (HUNTING, 1987; QUACK, 1976; REICH et al., 2009). Isso se deve a sua grande eficácia, versatilidade, disponibilidade e baixo custo. Devido à carga positiva, são substantivos ao cabelo, ligando-se aos sítios negativos superficiais. $\mathrm{O}$ tratamento resulta em um revestimento hidrofóbico da fibra , melhorando a sensação ao toque e a facilidade para pentear (FOERSTER; SCHWUGER, 1990), além de reduzir o efeito flyaway (JACHOWICZ; WIS-SUREL; GARCIA, 1985). Além disso, a deposição desses agentes no fio é maior quanto maior o número de sítios negativos, que é o que ocorre em cabelos danificados ou quimicamente tratados (REICH et al., 2009).

\subsubsection{Desenvolvimento de Formulações de Pré-tratamento (FPE)}

O desenvolvimento das formulações de pré-tratamento foi feito em duas etapas. A primeira teve como objetivo avaliar qual a melhor proporção de agente de consistência (AC) e base autoemulsionante (BA) para elaboração de formulações estáveis e com as características desejáveis para o uso proposto (FPE1 FPE2, FPE3 e FPE4). Ainda nessa etapa, avaliou-se se a adição da matéria-prima Cetil ésteres, impactaria no aspecto da formulação final (FPE5 e FPE6).

Observou-se que as formulações FPE3, FPE4 e FPE5 apresentaram as melhores características em relação à consistência de um creme capilar para tratamento, que conforme descito anteriormente, deve ser mais viscoso que condicionadores de uso diário. As formulações FPE1 e FPE2 ficaram com a consistência inferior a desejada e a adição da matéria-prima Cetil ésteres na FPE6, resultou em um creme com melhor aparência, mais branco e com mais brilho, quando comparado à formulação sem sua adição.

Em relação às formulações FPE7 e FPE8, que continham como base autoemulsionante o Cetearyl Alcohol and Dicetyl Phosphate and Ceteth-10 Phosphate, os resultados obtidos não foram satisfatórios. A consistência da formulação não estava adequada aos parâmetros desejados e não foi considerado que as vantagens na utilização dessa matéria-prima fossem significativamente maior às apresentadas pelo Behentrimonium Methosulfate (and) Cetyl Alcohol (and) Butylene Glycol, que já havia apresentado resultados satisfatórios. Sendo assim, 
foi suspenso o emprego do Cetearyl Alcohol and Dicetyl Phosphate and Ceteth-10 Phosphate na etapa de desenvolvimento e definido Behentrimonium Methosulfate (and) Cetyl Alcohol (and) Butylene Glycol como a base de escolha para o presente estudo.

Em uma segunda etapa do desenvolvimento, foi empregado o PPG-3 Benzyl Ether Ethylhexanoate como emoliente, substituindo os Triglicerídeos dos Ácidos Cáprico e Caprílico, devido aos benefícios específicos desse emoliente, conforme item 5.1.2. Outra alteração realizada nessa segunda etapa do desenvolvimento, foi a substituição do silicone empregado, optando pelo Amodimethicone (and) C11-15 Pareth-7 (and) Laureth-9 (and) Glycerin (and) Trideceth-12. A quantidade de propilenoglicol utlizada também foi maior e adicionou-se parte de água como componente da Fase C, com o objetivo de melhorar a dispersão da ceramida, facilitando sua incorporação, além de facilitar o resfriamento, uma vez que é adicionada em torno de $40^{\circ} \mathrm{C}$. Nessa etapa foram desenvolvidas quatro formulações de pré-tratamento, FPE9, FPE10, FPE11 e FPE12, com os novos componentes e variando a proporção de base autoemulsionante e agente de consistência.

Após as alterações realizadas na segunda etapa do desenvolvimento, as formulações mais adequadas foram selecionadas. Assim, as formulações FPE9, FPE11 e FPE12 foram selecionadas para as etapas posteriores do estudo, visto que foram consideradas como as mais adequadas na avaliação dos parâmetros aparência, estabilidade e consistência.

\subsubsection{Desenvolvimento de Formulações de Pós-tratamento (FPO)}

Em relação aos cremes desenvolvidos para a etapa de pós-tratamento, os melhores resultados foram obtidos para as formulações FPO2, FPO3 e FPO5. As formulações FPO1 e FPO4 ficaram com a consistência abaixo e acima da desejada, respectivamente. Da mesma forma que observado para a etapa de pré-tratamento, a adição da matéria-prima Cetil ésteres resultou em um creme com melhor aparência quando comparado à formulação sem sua adição (FPE6). De maneira geral, as formulações dessa etapa apresentaram-se mais consistentes. Embora o agente condicionante contendo o ácido 18-metileicosanoico não apresente como função ser um agente espessante, foi observado nesse estudo essa característica.

Após as alterações realizadas na segunda etapa de desenvolvimento, segundo descrito no item 5.1.3, as formulações FPO7, FPO8 E FPO9, apresentaram-se como as mais adequadas, sendo que a FPO10 estava com a consistência mais elevada que a desejada para os objetivos do estudo. 


\subsection{Avaliação da estabilidade}

\subsubsection{Centrifugação}

Todas as formulações desenvolvidas apresentaram-se estáveis após os três ciclos de centrifugação, sendo portanto levadas às análises subsequentes.

\subsubsection{Estabilidade preliminar}

De forma semelhante, não foram observadas mudanças macroscópicas nas características organolépticas de todas as formulações desenvolvidas, no período de 7 dias de acondicionamento na estufa a $45^{\circ} \mathrm{C}$.

\subsubsection{Acompanhamento do pH}

$\mathrm{Na}$ avaliação preliminar, os valores de $\mathrm{pH}$ mantiveram-se sem alterações estatisticamente significativas para todas as formulaçções testadas. Os valores das médias do valor de $\mathrm{pH}$ obtido nos sete dias de acompanhamento para cada formulação do pré-tratamento, encontramse descritos na Figura 7 e, para formulações do pós-tratamento, na Figura 8.

Figura 7:Valores de pH obtidos para as 12 formulações de pré-tratamento desenvolvidas (FPE1-12), durante os 7 primeiros dias após o preparo.

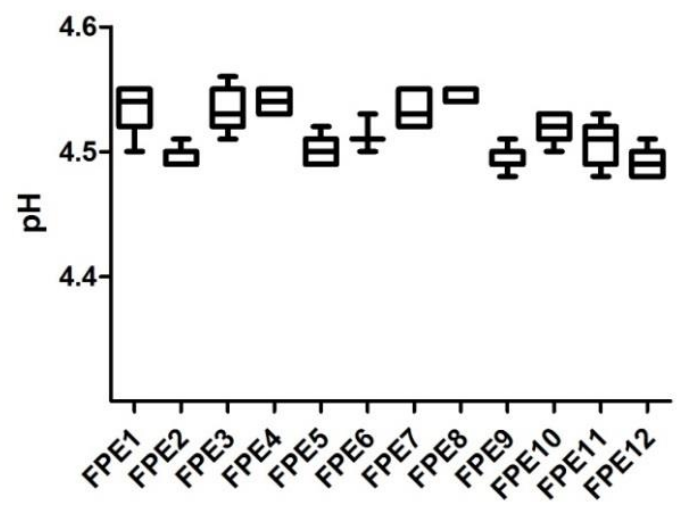


Figura 8:Valores de pH obtidos para as 10 formulações de pós-tratamento desenvolvidas (FPO1-10), durante os 7 primeiros dias após o preparo.

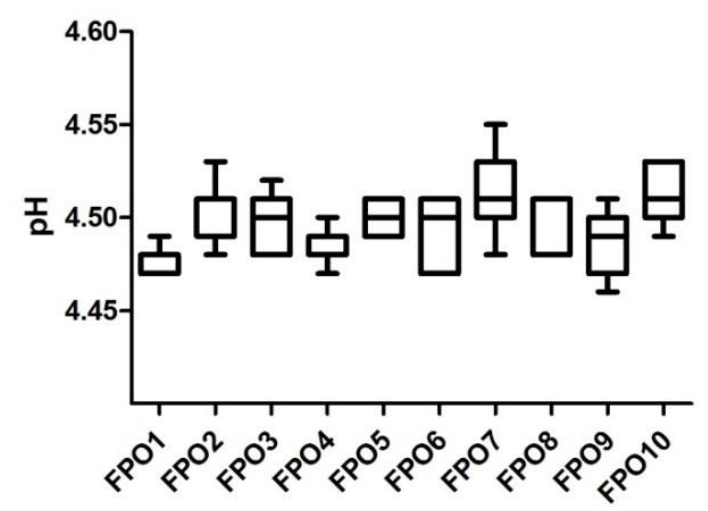

\subsubsection{Estabilidade Acelerada}

Ao final dos 90 dias de avaliação das formulações desenvolvidas e acondicionadas nas cámaras climáticas e na geladeira, todas mantiveram-se estáveis e sem alterações macroscópicas significativas. Dessa forma, foram consideradas com estabilidade adequada. Além disso, todas as formulações passaram na avaliação feita na centrífuga, ou seja, não apresentaram separação de fases após os 90 dias.

Sabe-se que durante o armazenamento e tratamento térmico, os óleos vegetais podem passar por hidrólise, oxidação e polimerização, resultando em perda da qualidade sensorial e eficácia, além de levar a alterações das características orgnolépticas das formulações. Embora os mecanismos desses processos sejam essencialmente os mesmos em diferentes lipídeos, a cinética dessas reações pode variar (CHE MAN et al., 1999). Considerando que misturas de óleos vegetais tem surgido como um método econômico de alterar características físicoquímicas dos óleos, além de aumentar a estabilidade oxidativa, e que misturas adequadas de óleos com grandes proporções de ácido oleico e linoleico podem resultar em compostos com características de estabililidade adequada (ANWAR et al., 2007; MARIOD; EICHNER; HUSSEIN, 2005), a associação dos diferentes óleos foi considerada benéfica para a estabilidade das formulações desenvolvidas no presente estudo. Apesar disso, sabe-se que por se tratar de uma formulação cosmética completa e, por isso, de composição complexa, outros fatores são essenciais para a estabilidade da formulação. Assim, tanto fatores relacionados aos componentes da formulação, como concentração de tensoativos e agentes de consistência, quanto os relacionados à técnica de preparo, tais como tempo e velocidade de agitação, influenciam na estabilidade final dos produtos cosméticos desenvolvidos. 


\subsubsection{Análise Sensorial}

Análise Sensorial é definida como a disciplina científica usada para evocar, medir, analisar e interpretar reações de como são percebidas as características dos alimentos e materiais pelos sentidos da visão, olfato, gosto, tato e audição.

A análise sensorial tem sido utilizada como instrumento de medida científica na avaliação da qualidade de cosméticos. As informações geradas com essas análises são muito importantes, devido ao fato de refletirem a opinião dos consumidores em potencial dos produtos desenvolvidos. Sendo assim, a análise sensorial em mechas de cabelo foi escolhida como parte da etapa de desenvolvimento racional de formulações.

Em relação ao parâmetro brilho, para as mechas que passaram pela etapa de prétratamento, não houve diferenças estatisticamente significativas para os diferentes tratamentos, embora os tratamentos com óleo de argan e abacate obtiveram notas maiores. Em relação ao pós-tratamento, houve diferença estatística entre os tratamentos com a formulação contendo a associação dos 3 óleos vegetais e a formulação contendo óleo de abacate, que obteve as menores notas. Para a avaliação da sedosidade, foram observadas diferenças estatísticas entre o pré-tratamento com a formulação contendo óleo de moringa, que apresentou as menores notas, e as formulações contendo óleo de abacate e óleo de argan, e, também, entre a formulação contendo óleo de abacate e a associação dos 3 óleos. Em relação ao pós-tratamento, houve diferença estatisticamente significativa entre a formulação contendo a associação dos 3 óleos, que recebeu as melhores notas, e todas as demais.

As Figuras 9 e 10 mostram o somatório das notas para o pré-tratamento e pós-tratamento, respectivamente, para as diferentes formulações. 
Figura 9: Somatório das notas dadas pelas voluntárias para os parâmetros (1) Brilho e (2) Sedosidade, na etapa de pré-tratamento.

(1)

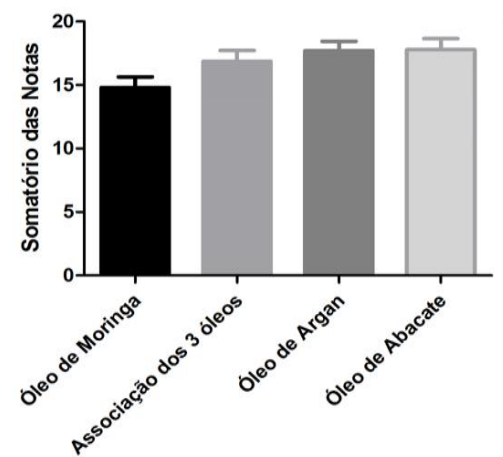

(2)

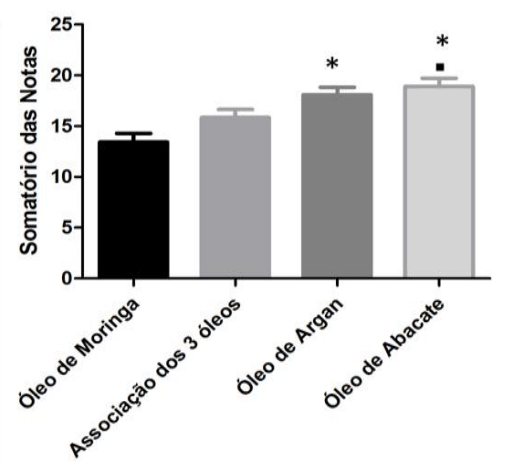

* diferença estatisticamente significativa em relação ao óleo de moringa.

- diferença estatisticamente significativa em relação a associação dos 3 óleos

Figura 10: Somatório das notas dadas pelas voluntárias para os parâmetros (1) Brilho e (2) Sedosidade, na etapa de pós-tratamento.

(1)

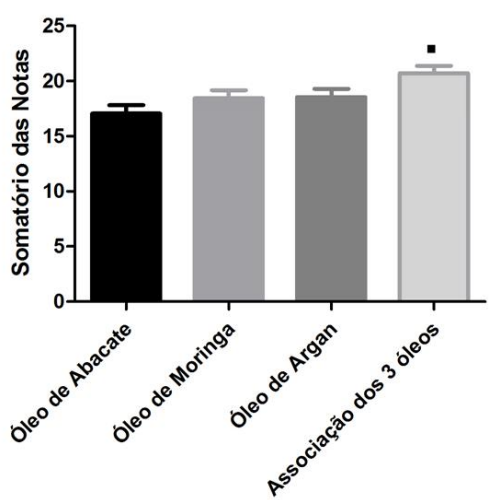

(2)

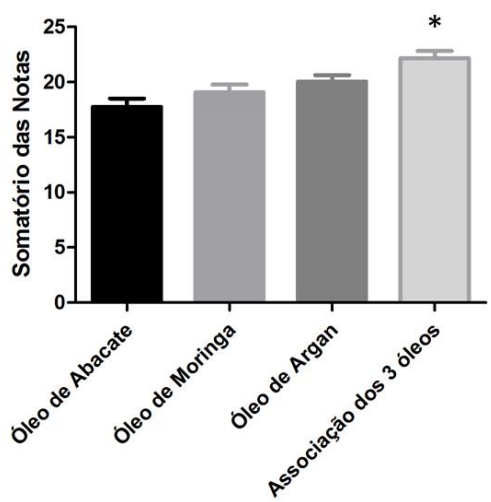

- diferença estatisticamente significativa em relação ao óleo de abacate.

*diferença estatisticamente significativa em relação aos demais tratamentos.

Como pode ser observado para os dois parâmetros avaliados, brilho e sedosidade, na etapa de pré-tratamento, as formulações contendo óleo de abacate e argan tiveram os melhores resultados, sendo que a formulação contendo óleo de abacate foi a melhor avaliada pelas painelistas.

Para a etapa de pós-tratamento, a formulação contendo a associação dos três óleos apresentou os melhores resultados para os dois parâmetros avaliados, sendo que as outras formulações tiveram notas semelhantes, sem diferenças estatisticamente significativas entre si.

Em outros estudos em que os óleos vegetais foram avaliados, foram observados bons resultados na melhoria das características sensoriais dos cabelos. Fregonesi e colaboradores descrevem que o óleo de buriti, por possuir uma distribuição homogênea em sua composição 
de ácidos graxos, com cerca de $79 \%$ de ácido oleico, torna a superfície dos cabelos mais suave e, consequentemente, com maior reflexão especular da luz (brilho) (FREGONESI et al., 2009). Associando esses resultados com os encontrados nesse estudo, nota-se que os óleos de abacate e moringa possuem concentração semelhante de ácido oleico quando comparado ao óleo de buriti, 72,2 e 71,8\%, respectivamente, o que pode explicar os resultados positivos obtidos na análise sensorial. O óleo de argan, embora possua menor concentração de ácido oleico, 45\%, possui esse ácido graxo como seu maior constituinte e levou a resultados semelhantes aos demais óleos, nas condições de estudo. De maneira geral, os óleos possuem essa capacidade de aumento do brilho devido a suas características lubrificantes e a fácil espalhabilidade sobre o cabelo (FREGONESI et al., 2009).

Os resultados demonstram que as painelistas participantes desse estudo foram capazes de diferenciar os diferentes tratamentos, principalmente para o parâmetro sedosidade, sendo que algumas relataram dificuldade em diferenciar visualmente o brilho entre as mechas avaliadas. Além disso, cabe salientar, que as notas atribuídas à etapa de pós-tratamento foram, em geral, mais altas do que na etapa de pré-tratamento. Isso pode ser atribuído ao fato de que, na etapa de pós-tratamento, foi adicionado à formulação o agente condicionante contendo o ácido 18metileicosanóico, que pode ter impactado positivamente na sensação ao toque, como previsto em dados da literatura. Entretanto, o objetivo da análise sensorial foi comparar os diferentes óleos dentro de cada etapa, pré ou pós-tratamento, e não entre essas duas etapas.

\subsection{Avaliação das propriedades mecânicas da fibra capilar}

Nessa etapa do estudo, foram avaliadas as propriedades mecânicas dos cabelos utilizando os valores médios de força máxima (gf) resistida pelos fios antes de sua ruptura.

Observando a Figura 11, pode-se avaliar as diferenças entre o valor máximo resistido pelo fio de cabelo entre os diferentes tratamentos com as formulações desenvolvidas, e quando comparado com a mecha que foi submetida ao processo de alisamento sem receber nenhum tratamento cosmético. Além disso, foi avaliada a mecha de cabelo que passou somente pelo alisamento térmico. Observando o gráfico, nota-se que foi necessária uma força média de 2052,0 gf para romper os fios de cabelo da mecha controle. Em relação a mecha submetida ao processo de alisamento químico à base de Hidróxido de Guanidina (grupo 14), a força máxima média necessária foi de 1846,8 gf por fio avaliado, ou seja, o dano químico levou a uma diminuição de cerca de $10 \%$ na resistência à ruptura da fibra capilar em relação ao cabelo virgem. 
Para as mechas dos grupos 2,3 e 4, que foram submetidas ao pré-tratamento com as diferentes formulações e, então, passaram pelo processo de alisamento a base de Hidróxido de Guanidina (H.G.), os resultados foram 1955,4; 1851,0 e 1930,4 gf, respectivamente. Houve diferenças estatisticamente significativas entre o tratamento com formulação contendo óleo de acabate e óleo de argan. Além disso, todos os tratamentos resultaram em diferenças estatisticamente diferentes em relação ao grupo 14 , que foi submetido ao dano químico e não teve nenhum tratamento com as formulações cosméticas desenvolvidas. Sendo assim, o prétratamento foi eficaz na diminuição do dano causado pelo processo de alisamento químico a base de Hidróxido de Guanidina.

Figura 11: Valores de Força Máxima (gf) resisitida pelo fio de cabelo até sua ruptura na etapa de pré-tratamento com Hidróxido de Guanidina (H.G.).

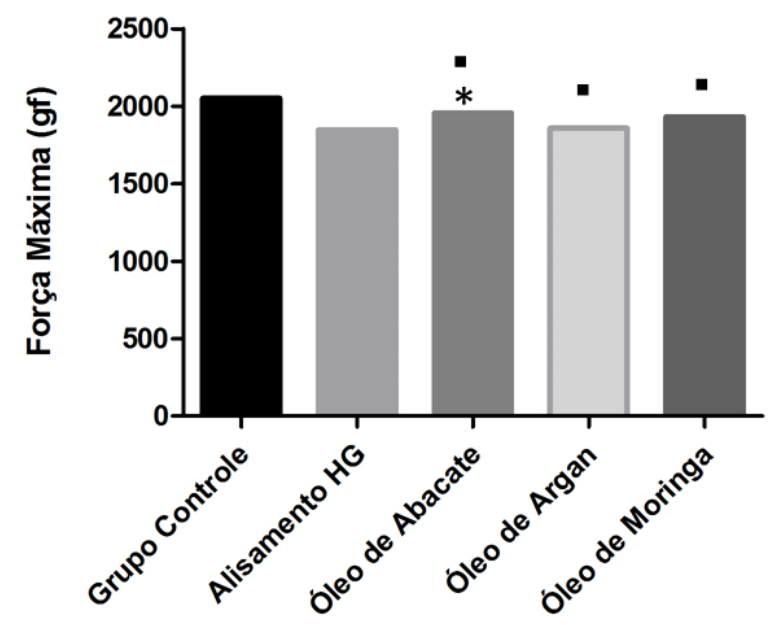

\footnotetext{
* Diferença estatisticamente significativa em relação ao tratamento com formulação contendo óleo de argan. - Diferença estatisticamente significativa em relação ao grupo que não recebeu tratamento com os óleos vegetais.
}

Todos os tratamentos realizados aumentaram a força máxima, se comparado com as amostras sem tratamento, embora ainda menor que os valores do controle. O tratamento à base de óleo de abacate apresentou o melhor resultado, levando a uma redução de 4,71\% da força máxima necessária para ruptura do fio em relação ao grupo controle, seguido do óleo de moringa, 5,92\% e de Argan 9,50\%. Esses resultados indicam que o tratamento realizado teve um efeito na proteção do cabelo contra o dano químico e que um tratamento realizado por um período maior poderia se aproximar mais dos resultados do grupo controle.

Na Figura 12, encontram-se descritos os resultados relacionados ao pré-tratamento em mechas alisadas com creme contendo Tioglicolato de Amônio, grupos 5,6, 7 e 8, em que os valores encontrados foram 1745,4; 1801,4; 1752,6 e 1901,4 gf, respectivamente. Também nesse caso todos os tratamentos forneceram valores melhores do que os obtidos na mecha 
submetida somente ao processo de alisamento, que foi de 1581,0 gf, com resultados estatisticamente diferentes. Além disso, foram encontradas diferenças estatísticas entre o tratamento feito com os tratamentos com óleo de abacate, argan e a associação entre os três óleos quando comparado ao tratamento com óleo de moringa, que obteve os piores resultados. A asssociação entre os três óleos foi, ainda, superior em relação ao tratamento com óleo de argan isolado, com diferenças estatisticamente significativas entre os tratamentos. Apresentando os valores da redução da força máxima necessária para ruptura dos fios em relação ao grupo controle, tem-se os seguintes resultados: redução de 14,$97 ; 12,21 ; 14,59$ e 7,34\% para formulações contendo óleo de moringa, abacate, argan e associação dos três óleos, respectivamente. Nota-se que também o óleo de abacate forneceu os melhores resultados quando avaliados somente os óleos isolados e que a associação dos 3 óleos resultou em um efeito sinérgico, com a menor redução da força de ruptura máxima em relação ao grupo controle observada nesta avaliação.

Figura 12: Valores de Força Máxima (gf) resisitida pelo fio de cabelo até sua ruptura na etapa de prétratamento com Tioglicolato de Amônio (T.A.).

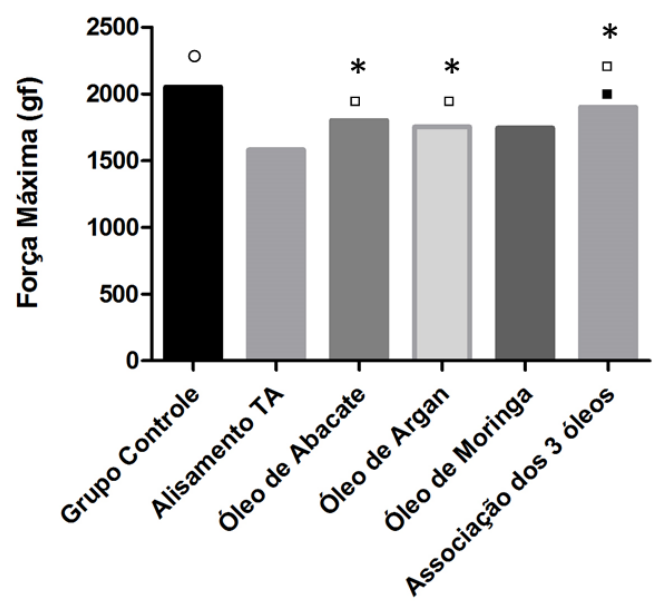

* Diferença estatisticamente significativa em relação ao tratamento com formulação contendo óleo de moringa. - Diferença estatisticamente significativa em relação ao grupo que não recebeu tratamento com os óleos vegetais. - Diferença estatisticamente significativa em relação ao tratamento com formulação contendo óleo de argan.

- Diferença estatisticamente significativa em relação a todos os tratamentos.

Ainda em relação ao alisamento a base de Tioglicolato de Amônio, os valores encontrados para a etapa de pós tratamento, grupos 9,10,11 e 12, foram 1789,4; 1909,2; 1794,4 e 2010,8 gf, respectivamente. Também nesse caso todos os tratamentos forneceram valores melhores do que os obtidos na mecha submetida somente ao processo de alisamento, com diferenças estatisticamente significativas entre os tratamentos. Além disso, foram encontradas diferenças estatisticamente significativas entre o tratamento a base de óleo de 
abacate e da associação dos 3 quando comparados com os óleos de moringa e argan. Esses resultados podem ser observados na Figura 13.

Figura 13: Valores de Força Máxima (gf) resisitida pelo fio de cabelo até sua ruptura na etapa de pós-tratamento com Tioglicolato de Amônio (T.A.)

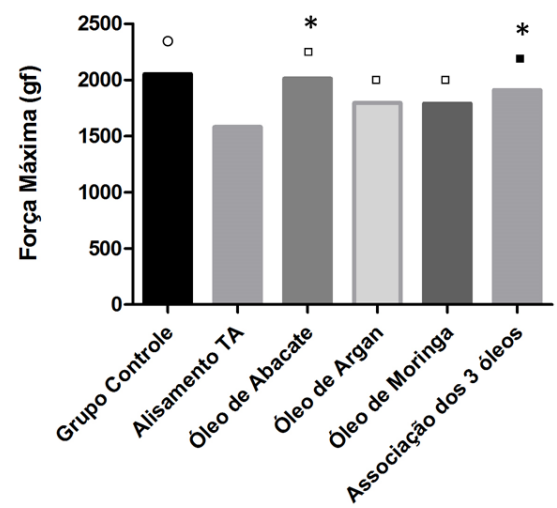

\footnotetext{
* Diferença estatisticamente significativa em relação ao tratamento com formulação contendo óleo de argan, moringa e a associação dos 3 óleos..

- Diferença estatisticamente significativa em relação ao grupo que não recebeu tratamento com os óleos vegetais.

- Diferença estatisticamente significativa em relação ao tratamento com formulação contendo óleo de argan e óleo de moringa.

${ }^{\circ}$ Diferença estatisticamente significativa em relação a todos os tratamentos.
}

De acordo com os referidos resultados, observa-se que, para os dois tipos de alisamento empregados, as formulações objeto de estudo foram capazes de diminuir o dano causado à fibra capilar, uma vez que o valor da força máxima de ruptura dos fios foi maior do que quando não houve tratamento cosmético. As diferenças entre os óleos gerou resultados satisfatórios para o objetivo proposto e foi visto que o óleo de abacate forneceu os melhores valores, dentre os óleos empregados isoladamente, para os dois tipos de alisamento e também para as duas etapas avaliadas, pré e pós-tratamento. A associação dos 3 óleos mostrou melhores resultados para a etapa de pré-tratamento e resultado semelhante ao obtido com o óleo de abacate para a etapa de pós-tratamento, indicando um efeito sinérgico da associação de óleos vegetais com diferentes propriedades.

Cabe salientar que, embora seja descrito que os alisamentos à base de hidróxidos causam mais danos à fibra capilar, quando comparado ao tioglicolato de amônio (WOLFRAM, 2003), os resultados desse estudo foram diferentes. Isso pode ser justificado pelo fato que, dentre os alisamentos à base de hidróxido, o hidróxido de guanidina é considerado o mais suave, e consequentemente, com menor poder alisante. Além disso, existiam 4 opções de produtos a base de tioglicolato de amônio, com forças de ação 
diferentes. Neste estudo foi empregado o produto com maior poder alisante, que possui maior concentração de ativo e pH mais elevado. Ainda em relação a diferença observada em relação à literatura, o tioglicolato de amônio é, na prática em salões de beleza, apontado como agente que causa mais danos quando comparado ao hidróxido de guanidina

Considerando os resultados obtidos nas duas etapas, análise sensorial e avaliação da resistência capilar, pode-se descrever em síntese:

1)Pré-tratamento:

Análise Sensorial: Formulações contendo óleo de abacate e óleo de argan tiveram melhores resultados.

Força máxima de ruptura: A formulação contendo a associação dos 3 óleos obteve o melhor resultado, seguido da formulação contendo óleo de abacate.

Considerando esses resultados, juntamente com os demais benefícios atribuídos a cada um dos óleos empregados, a formulação de escolha para seguir para etapa do estudo reológico é a associação dos óleos de moringa, argan e abacate. Embora o óleo de moringa tenha tido notas inferiores aos demais óleos, possui importância para a estabilidade da formulação (ANWAR et al., 2007; KLEIMAN; ASHLEY; BROWN, 2008), sendo, portanto, mantido na composição da formulação final.

2)Pós-tratamento:

Análise Sensorial: Formulações contendo a associação dos 3 óleos teve o melhor resultado, seguido do óleo de argan.

Força máxima de ruptura: A formulação contendo a associação dos 3 óleos obteve o melhor resultado, seguido da formulação contendo óleo de abacate.

Considerando os resultados descritos, o óleo de abacate apresentou os melhores resultados quando comparado aos demais óleos isolados, entretanto a associação dos 3 óleos gerou efeito sinérgico, sendo superior ao óleo de abacate isoladamente. Dessa forma, a formulação de escolha para seguir para etapa do estudo reológico é a associação dos óleos de moringa, argan e abacate.

\subsection{Estudo reológico das formulações}

Como demonstrado nas etapas anteriores, a formulação contendo a associação dos 3 óleos vegetais em estudo foi a escolhida tanto para a etapa de pré-tratamento, quanto para a de póstratamento. 
$\mathrm{Na}$ etapa do estudo reológico, o objetivo foi avaliar qual a proporção de base autoemulsionante (BA):agente de consistência (AC) forneceria os melhores resultados em relação à estabilidade. Para a etapa de pré-tratamento, a melhor proporção BA:AC foi 3:3, como representado na Figura 14 e seu respectivo veículo, Figura 15, e de 3:4, para a etapa de pós-tratamento (Figuras 16 e 17). A análise foi feita observando, durante os 28 dias avaliados, quais formulações sofreriam menos alterações, evidenciadas pela sobreposição das curva nos diferentes tempos. A comparação com o veículo é importante para verificação da influência da adição dos óleos vegetais no comportamento da curva reológica. Observou-se que , de maneira geral, há um aumento da tixotropia com o aumento da concentração de fase oleosa da formulação.

Figura 14 - Reograma de pré-tratamento com ativos, proporção BA:AC igual a 3:3, armazenada no (A) ambiente, (B) $37^{\circ} \mathrm{C}$, (C) $45^{\circ} \mathrm{C}$ e (D) $4^{\circ} \mathrm{C}$, por um período de 28 dias.

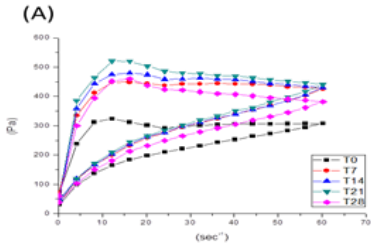

(C)

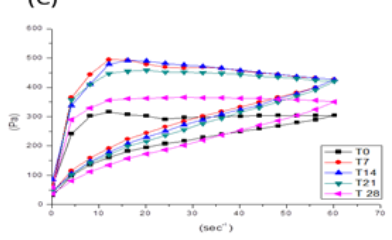

(B)

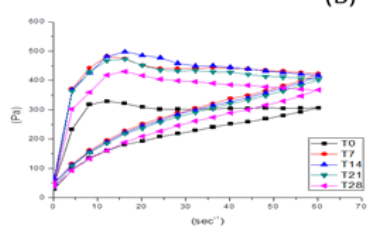

(D)

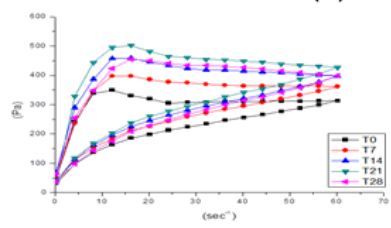

Figura 15 - Reograma de pré-tratamento veículo, proporção BA:AC igual a 3:3, armazenada no (A) ambiente, (B) $37^{\circ} \mathrm{C},(\mathrm{C}) 45^{\circ} \mathrm{C}$ e (D) $4^{\circ} \mathrm{C}$, por um período de 28 dias.

(A)

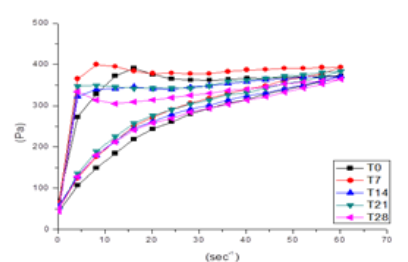

(C)

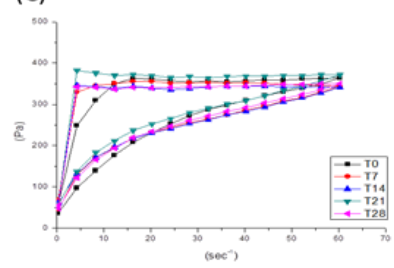

(B)

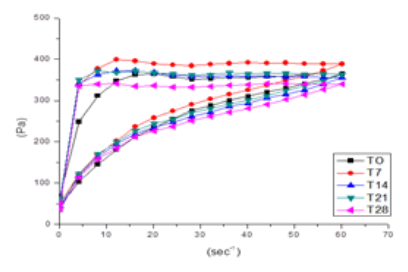

(D)

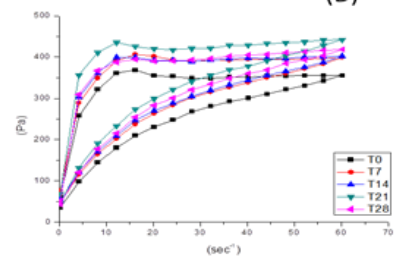


Figura 16 - Reograma de pós-tratamento com ativos, proporção BA:AC igual a 3:4, armazenada no (A) ambiente, (B) $37^{\circ} \mathrm{C},(\mathrm{C}) 45^{\circ} \mathrm{C}$ e (D) $4^{\circ} \mathrm{C}$, por um período de 28 dias.

(A)

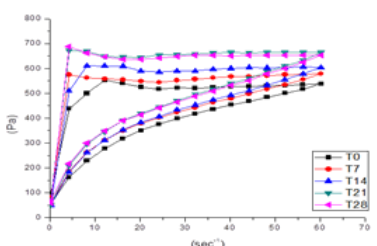

(C)

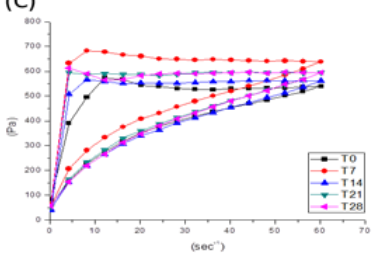

(B)

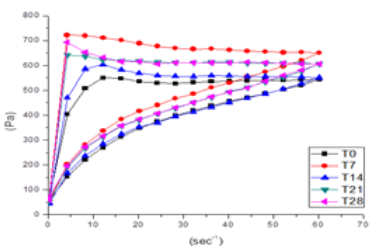

(D)

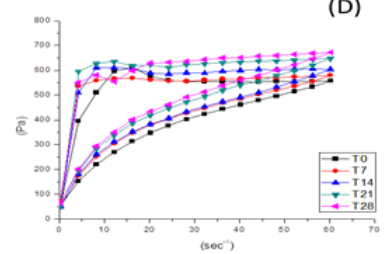

Figura 17 - Reograma de pós-tratamento veículo, proporção BA:AC igual a 3:4, armazenada no (A) ambiente, (B) $37^{\circ} \mathrm{C}$, (C) $45^{\circ} \mathrm{C}$ e (D) $4^{\circ} \mathrm{C}$, por um período de 28 dias.

(A)

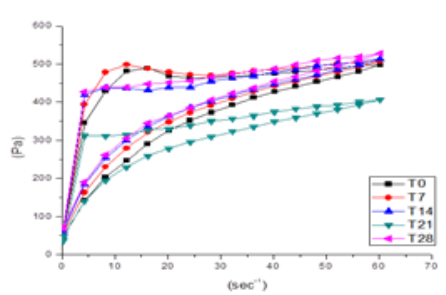

(C)

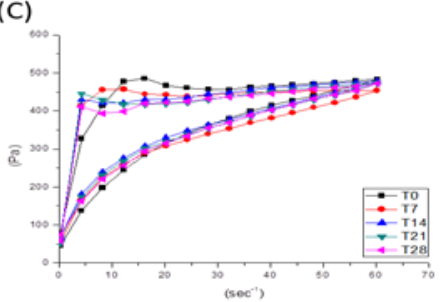

(B)

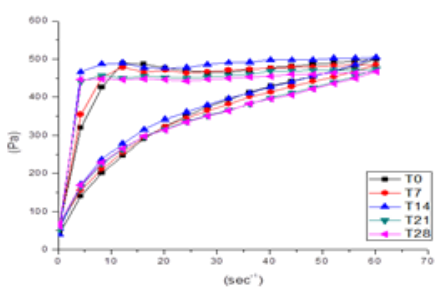

(D)

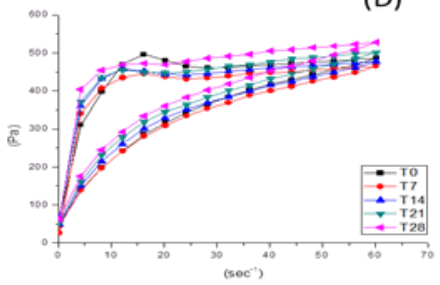

Como apresentado nas Figuras 14 a 17, a formulação em estudo manteve-se estável no período avaliado, conservando suas características de acordo com os parâmetros desejados para este estudo. Foi feito o teste de adesão ao modelo matemático e a equação que melhor descreve o comportamento reológico das formulações foi o modelo de Cross com adição do termo Yield Stress, uma vez que o coeficiente de correlação, $\mathrm{R}^{2}$, foi igual 0,99. 
O emprego da avaliação reológica permitiu escolher dentre as três formulações de prétratamento e 3 de pós-tratamento, desenvolvidas alterando a proporção de Base Auto emulsionante e Agente de Consistência, qual se manteve mais estável ao final dos 28 dias. Isso foi importante para o direcionamento racional da definição da formulação final a ser empregada para a prevenção e tratamento de cabelos submetidos a radiação solar.

\subsection{Acompanhamento do pH}

Os valores de pH das formulações mantiveram-se estáveis, na faixa de 4,3 a 4,6 após 28 dias de estudo, sendo um importante indício de que as formulações se mantiveram estáveis durante o período de tempo avaliado, uma vez que mudanças nos valores de $\mathrm{pH}$ poderiam indicar processo de instabilidade, como oxidação dos óleos vegetais adicinados.

\subsection{Avaliação das mechas de cabelo expostas à radiação solar}

\subsubsection{Avaliação das propriedades mecânicas}

\subsubsection{Diâmetro dos fios de cabelo}

Foram escolhidos 20 fios de cabelo de cada uma das três mechas constituintes dos grupos de tratamento, conforme descrito na Figura 6. A fim de verificar se a escolha do grupo de 20 fios de cabelo foi adequada, foi feita a análise de variância (one way ANOVA) utilizando o software estatístico GraphPad Prisma 5.0, dos 60 valores, correspondentes aos 20 diâmetros de cada uma das 3 replicatas do grupo. Não houve diferença estatística entre os valores obtidos, demonstrando a homogeneidade da amostra selecionada. Da mesma forma, foi feita o teste one way ANOVA entre todos os valores correspondentes ao tempo 0 (T0), antes da exposição das mechas ao simulador solar, de todos os grupos de tratamento. Nesse caso, verificou-se diferença estatisticamente significativa entre os grupos. Em outras palavras, a opção em utilizar cada mecha como sendo o seu próprio controle (T0) foi adequada, visto que, pelo resultado da análise estatística, não seria adequado utilizar apenas um grupo de mechas como sendo o controle, uma vez que os valores do diâmetro para cada grupo de tratamento não foram considerados estatisticamente iguais. 


\subsubsection{Avaliação da resistência do fio de cabelo}

Tanto a radiação UVB quanto a UVA causam fotodegradação do cabelo, envolvendo tanto as proteínas (queratina) quanto os pigmentos (melanina). A foto-oxidação ocorre na ligação C-S da cistina, resultando na formação do ácido cisteico em um mecanismo de reação via radicais livres (FERNÁNDEZ et al., 2012a; RUETSCH; KAMATH, 2000; SIGNORI, 2004). Essa alteração é capaz de modificar as propriedades mecânicas do fio em condições de exposição prolongada à radiação solar, especialmente sua fração ultravioleta (DUBIEF, 1992; HERRLING; JUNG; FUCHS, 2008; RICHARD BEYAK; KASS; MEYER, 1971). Dessa maneira, a exposição das mechas de cabelo em um simulador solar, levou a uma diminuição da resistência do fio à quebra.

Os resultados demonstram que, os diferentes tratamentos foram capazes de alterar significativamente os valores de Força Máxima obtidos no teste realizado no Texturômetro. As análises estatísticas foram realizadas comparando os resultados obtidos no tempo 144 (T144), ou seja, após 144h de exposição das mechas ao Simulador Solar, com os resultados das mechas no T0, que correspondem às mechas sem nenhum tratamento nem exposição à radiação solar.

Como pode ser observado na Figura 18, o cabelo irradiado (CI) que não passou por nenhum tratamento cosmético, apresentou uma diminuição significativa da força máxima registrada para ruptura do fio. Comportamento semelhante foi registrado para as mechas tratadas somente com as formulações veículo, tanto do pré (VPE) quanto do pós-tratamento (VPO). Assim, pode-se concluir que somente os veículos não foram suficientes para reparar ou proteger a fibra da ação da radiação solar. Por outro lado, as mechas submetidas ao prétratamento com as demais formulações (VPEF, VPEO e VPEOF) mantiveram a resistência à quebra próxima aos valores obtidos antes de qualquer exposição ao dano da radiação solar. Assim, concluiu-se que tanto a adição do filtro solar e dos óleos vegetais, isoladamente, quanto a combinação desses dois ativos, protegeram a integridade da fibra capilar. Conforme proposto por Pande e Jachowicz, um dos modos eficazes de proteger a fibra do cabelo é reduzindo a quantidade de radiação solar que chega à sua estrutura (PANDE; JACHOWICZ, 1993). Isso é obtido com o emprego do filtro solar, que explica os resultados obtidos para as mechas tratadas com as formulações VPEF e VPEOF. Considerando que o córtex, principal responsável pela resistência do fio, é protegido pela cutícula, danos nessa região ocorrem após extensivos danos na camada cuticular. Dessa forma, avaliando as imagens obtidas com o Microscópio Eletrônico de Varredura, item 5.7.3, é possível observar que o cabelo irradiado 
sem nenhum tratamento cosmético teve grande comprometimento da camada superficial capilar, com diversas regiões onde havia exposição do córtex, com a perda de camadas de cutícula. Dessa forma, nota-se que, de fato, as mechas irradiadas ficaram mais suceptíveis a danos que envolvessem diminuição da resistência mecânica do fio, devido a essa exposição do córtex. Assim, a importância das formulações na etapa de pré-tratamento é muito grande, de forma a manter a integridade da superfície capilar mais próxima do observado no cabelo virgem. De maneira não esperada, a adição dos óleos vegetais na etapa de pós-tratamento teve um efeito muito semelhante ao observado na etapa de pré-tratamento, de forma que a resistência do cabelo foi preservada, o que não ocorreu com a aplicação do veículo. Nesse caso, a explicação proposta é o efeito antioxidante dos óleos vegetais, de maneira que, mesmo com o comprometimento da camada superficial, expondo mais o córtex capilar à radiação solar, o efeito antioxidante atuou na minimização dos danos que seriam causados sem esse mecanismo de proteção. O poder antioxidante dos óleos é devido a grande concentração de tocoferóis em suas porções insaponificáveis.

A coerência dessa justificativa baseia-se no no mecanismo proposto para a oxidação da cistina em ácido cisteico, que é via radicais livres. Como a formação do ácido cisteico está relacionada a menor resistência capilar, os óleos atuariam evitando a sua formação ao agir como antioxidantes (FERNÁNDEZ et al., 2012a; RUETSCH; KAMATH; WEIGMANN, 2001; SIGNORI, 2004). Esse resultado está de acordo com o obtido por Fernández e colaboradores, que obtiveram melhora nas propriedades mecânicas do cabelo e em outros parâmetros avaliados, quando utilizaram antioxidantes naturais (FERNÁNDEZ et al., 2012b).

Em geral, óleos saturados e monoinsaturados penetram no cabelo devido a sua estrutura molecular compacta e à cabeça polar das moléculas de triglicerídeos que constituem esses óleos (KEIS et al., 2005). Em um modo dinâmico essas moléculas podem passar pelo CMC. Por outro lado, óleos poli-insaturados não penetram no cabelo, provavelmente devido à estrutura menos compacta, mais aberta de suas moléculas de triglicerídeos e também pela presença de múltiplas ligações (KEIS; HUEMMER; KAMATH, 2007). Considerando que existem efeitos benéficos resultantes tanto da penetração do óleo na fibra capilar, quanto da sua adesão à superfície (RUETSCH; KAMATH; WEIGMANN, 2001), a associação de diferentes óleos é interessante, por possuirem composições químicas diferentes, capazes de proporcionar maior número de benefícios.

Keis e colaboradores compararam a habilidade de diferentes óleos em penetrar na fibra capilar, mostrando que sua afinidade com os cabelos depende de vários fatores, como a polaridade do óleo, saturação da cadeia e peso molecular. Nesse mesmo estudo, foi observado 
que a adição de óleo de Argania spinosa reduziu estatisticamente a perda proteica quando comparada somente com a formulação veículo (CHARROUF; GUILLAUME, 2008; KEIS et al., 2005). Embora no presente estudo não tenha sido avaliada a perda proteica dos fios submetidos a radiação solar, o resultado positivo encontrado na avaliação da resistência das mechas de cabelo tratadas com os óleos vegetais, também pode estar relacionado a uma diminuição da perda proteica, impactando na manutenção da resistência da fibra capilar. A extrapolação desse resultado para o presente estudo baseia-se em em resultados, nos quais foi verificado que a adição de componente hidrofóbicos, como o óleo de argan, reduziu a tendência de intumescimento da cutícula, diminuindo a perda de células cuticulares e, consequentemente, a perda proteica (CHARROUF; GUILLAUME, 2008; FARIA et al., 2013).

No presente estudo, a combinação dos três óleos vegetais, em uma concentração total de $1,5 \%$ nas formulações desenvolvidas, levaram a um efeito positivo na manutenção da integridade estrutural da fibra capilar. Isso foi confirmado pelos resultados obtidos também na etapa de pós-tratamento, uma vez que nessa etapa não houve adição do filtro solar, mas a formulação contendo os óleos vegetais (VPOO) foi capaz de recuperar os danos causados pela exposição à radiação solar, ao contrário do resultado obtido com a utilização apenas do veículo.

Figura 18: Valores de Força Máxima (N) obtidos para as mechas de cabelo, submetidas ou não ao tratamentocom as formulações cosméticas desenvolvidas, antes e após exposição ao Simulador Solar.

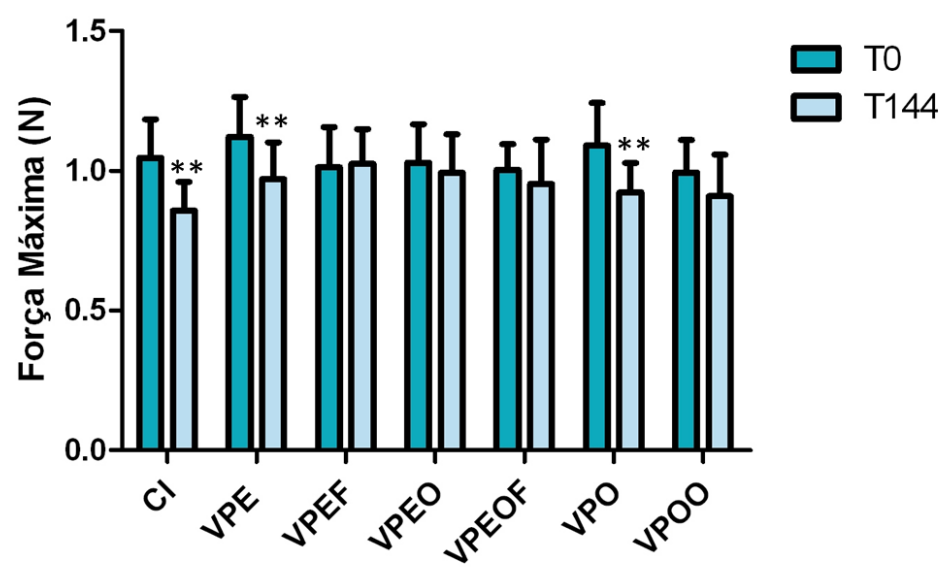

Legenda: CI: mechas irradiadas no simulador solar sem nenhum tratamento cosmético; VPE: mechas tratadadas com veículo de pré-tratamento; VPEF: mechas tratadas com veículo de pré-tratamento adicionado de filtro solar; VPEO: mechas tratadas com veículo de pré-tratamento adicionado dos óleos vegetais; VPEOF: mechas tratadas com veículo de pré-tratamento adicionado dos óleos vegetais e filtro solar; VPO: mechas tratadadas com veículo de pós-tratamento e VPOO: mechas tratadas com veículo de pós-tratamento adicionado dos óleos vegetais. ${ }^{* *} \mathrm{p}<0,001$ do T144 em relação ao seu controle T0. 
É importante observar que existem efeitos benéficos resultantes tanto da penetração do óleo na fibra capilar, quanto da sua adesão à superfície. A magnitude desses dois efeitos depende da espessura do filme de óleo, determinado pela quantidade de óleo aplicada e pela quantidade que penetra na fibra. A penetração até o córtex é desejada, uma vez que as propriedades mecânicas da fibra capilar são determinadas pelo córtex (RUETSCH; KAMATH; WEIGMANN, 2001). A difusão ou capacidade de penetração de pequenas moléculas é esperada como sendo via complexo da membrana celular, controlado pela afinidade das moléculas por proteínas do CMC, estrutura molecular e peso molecular . A afinidade dos óleos vegetais pelo cabelo é explicada por sua constituição rica em triglicerídeos, nos quais três moléculas de ácidos graxos são naturalmente esterificadas com três grupos hidroxila de um esqueleto glicerol. Ao contrário do óleo mineral, por exemplo, que não difunde para a fibra capilar por falta de afinidade, uma vez que é apolar e constituído de uma cadeia de hidrocarbonetos (KEIS; HUEMMER; KAMATH, 2007). Dessa forma, embora a penetração dos óleos não tenha sido avaliada nesse estudo, possivelmente isso ocorreu, justificando os resultados na avaliação da resistência mecânica capilar. Além disso, a presença de filmes de óleo na superfície leva a uma adesão capilar entre as fibras, aumentando a reflexão especular da luz pela superfície (KEIS; HUEMMER; KAMATH, 2007;

RUETSCH; KAMATH; WEIGMANN, 2001). Dessa maneira, a mistura sinérgica de composições de óleos vegetais possui importante papel, como observado nos resultados obtidos no presente estudo.

Cabe salientar que os óleos vegetais utlizados neste estudo não foram avaliados com sua aplicação direta nos cabelos e sim incorporados em formulações cosméticas, aumentando ainda mais a complexidade dos mecanismos envolvidos na ação protetora e reparadora dessas formulações. Apesar disso, estudos anteriores obtiveram resultados positivos na proteção cuticular, redução da perda proteica e diminuição da penetração de água para o interior da fibra, utilizando um óleo vegetal incorporado em um condicionador, aplicado em mechas submetidas ao teste de penteabilidade, quando comparado somente ao veículo (RELE; MOHILE, 2003).

\subsubsection{Avaliação da variação de cor das mechas de cabelo}

É bem conhecido que a radiação ultravioleta (UV) danifica o cabelo humano. A radiação UV, notadamente a UVB, ataca tanto os pigmentos de melanina presentes na fibra, quanto a fração proteica (queratina) (NOGUEIRA; DICELIO; JOEKES, 2006). É bem documentado 
que o cabelo, que é composto principalmente por proteínas $(65-95 \%$ em peso)(BOLDUC; SHAPIRO, 2001; ROBBINS, 2012) é vulnerável a fotodegradação, sendo que pelo número de estudos publicados discutindo o assunto, parece haver um consenso que a radiação ultravioleta e visível é capaz de alterar a composição química, a morfologia e a aparência do cabelo humano (SIGNORI, 2004).

De acordo com a maior parte dos estudos nessa área a fotodegradação resulta no amarelamento do cabelo branco após a exposição solar (PLOWMAN et al., 2013), em um clareamento do cabelo devido a oxidação da melanina via radicais livres e na indução de danos à queratina (NOGUEIRA et al., 2007, 2004).

O objetivo de realizar análises de variação de cor nas mechas analisadas nesse estudo, foi verificar comparativamente se os tratamentos com as formulações cosméticas seriam eficazes na prevenção e manutenção da cor dos fios. Foram utilizadas mechas castanho-escuro.

Devido a indisponibilidade do emprego da técnica de espectroscopia de reflectância difusa, foram feitas análises em dois colorímetros diferentes para verificar a concordância dos dados obtidos.

Os resultados obtidos demonstram não haver concordância entre os dados obtidos para as análises realizadas com o Skin Colorimeter ${ }^{\circledR}$ e para o Chromameter ${ }^{\circledR}$, conforme descrito nas Tabelas 6 e 7. Nessas tabelas estão descritos os valores obtidos da diferença entre os dados da análise no tempo 144 (T144 - após 144h de exposição no simulador solar, após diferentes tratamentos com as formulações cosméticas) e no tempo 0 (T0 - mechas antes da exposição solar e dos tratamentos com as formulações cosméticas). Assim, DL* correponde a diferença da Luminosidade $\left(\mathrm{L}^{*}{\mathrm{~T} 144^{-}}^{\mathrm{L}^{*} \mathrm{~T} 0}\right), \mathrm{Da}^{*}$ é a diferença entre o eixo vermelho-verde $\left(\mathrm{a}^{*} \mathrm{~T}_{144^{-}} \mathrm{a}^{*} \mathrm{~T} 0\right)$ e Db* é a diferença entre o eixo amarelo-azul (a*T144- ${ }^{*}{ }^{*}$ T0) (RICHENA et al., 2014). 
Tabela 6- Valores de $\mathrm{DL}^{*}, \mathrm{Da}^{*}$ e $\mathrm{Db}^{*}$ obtidos para as mechas de cabelo empregando o equipamento Skin Colorimeter $^{\circledR}$

\begin{tabular}{cccc}
\hline Tratamentos & DL* & $\mathrm{Da}^{*}$ & $\mathrm{Db}^{*}$ \\
CI & $0,979 \pm 0,668$ & $0,094 \pm 0,463$ & $1,300 \pm 2,275$ \\
VPE & $1,628 \pm 1,351$ & $0,366 \pm 0,469$ & $-0,462 \pm 2,306$ \\
VPEF & $1,015 \pm 0,981$ & $0,095 \pm 0,297$ & $0,521 \pm 1,663$ \\
VPEO & $0,641 \pm 1,267$ & $-0,010 \pm 0,722$ & $2,603 \pm 1,463$ \\
VPEOF & $0,043 \pm 0,350$ & $-0,204 \pm 0,263$ & $2,596 \pm 1,684$ \\
VPO & $-0,524 \pm 0,139$ & $-0,046 \pm 0,231$ & $2,385 \pm 0,781$ \\
VPOO & $-0,637 \pm 0,783$ & $-0,650 \pm 0,500$ & $4,947 \pm 1,711$ \\
\hline
\end{tabular}

Devido à heterogeneidade inerente a medição de cores do cabelo, o desvio padrão é levado em consideração para delimitar quais resultados são considerados variações reais na cor, considerando o erro e variação da técnica. Sendo assim, observa-se que, ao contrário de resultados obtidos em outros estudos (NOGUEIRA et al., 2007; RICHENA et al., 2014), não foi o parâmetro $L^{*}$ que teve variações mais significativas nas medidas utilizando o equipamento Skin Colorimeter ${ }^{\circledR}$ e sim o parâmetro $b^{*}$. Entretanto, esse resultado não foi considerado válido, uma vez que considerando a cor das mechas empregadas (castanhoescuro), as medidas iniciais no espaço da cor $\mathrm{L}^{*} \mathrm{a}^{*} \mathrm{~b}^{*}$, forneceram valores de $\mathrm{b}^{*}$ bem diferentes dos relatados na literatura para mechas padrão, do mesmo fornecedor (De Meo Brother Inc. Nova York) (FERNÁNDEZ et al., 2012b; NOGUEIRA et al., 2007; RICHENA et al., 2014). As outras coordenadas, $\mathrm{L}^{*}$ e $\mathrm{a}^{*}$, tiveram valores semelhantes aos publicados na literatura. Ao contrário, os valores obtidos com o Chromameter $^{\circledR}$, levou a valores semelhantes para todas as coordenadas ( $\mathrm{L}^{*} \mathrm{a}^{*} \mathrm{~b}^{*}$ ). Além disso, existem estudos (FUKUHARA; NOJIRI, 2011; GERRARD, 1989; NAYSMITH et al., 2004) que empregam este equipamento para avaliação de variação das cores em mechas de cabelo, o que não foi encontrado para o Skin Colorimeter $^{\circledR}$. Considerando tudo isso, os valores obtidos com o emprego do Chromameter ${ }^{\circledR}$ foram considerados mais adequados para o estudo. 
Tabela 7- Valores de $\mathrm{DL}^{*}, \mathrm{Da}^{*}$ e $\mathrm{Db}^{*}$ obtidos para as mechas de cabelo empregando o equipamento Chromameter $^{\circledR}$

\begin{tabular}{llll}
\hline Tratamentos & \multicolumn{1}{l}{$\mathrm{DL}^{*}$} & $\mathrm{Da}^{*}$ & $\mathrm{Db}^{*}$ \\
\hline CI & $-0,077 \pm 0,311$ & $-0,018 \pm 0,424$ & $-0,141 \pm 0,538$ \\
VPE & $0,406 \pm 0,448$ & $-0,888 \pm 0,396$ & $0,690 \pm 0,771$ \\
VPEF & $0,322 \pm 0,364$ & $-0,175 \pm 0,404$ & $0,558 \pm 0,620$ \\
VPEO & $0,124 \pm 0,326$ & $0,093 \pm 0,436$ & $0,179 \pm 0,592$ \\
VPEOF & $-0,230 \pm 0,378$ & $-0,242 \pm 0,391$ & $-0,408 \pm 0,648$ \\
VPO & $0,077 \pm 0,364$ & $-0,562 \pm 0,368$ & $0,125 \pm 0,624$ \\
VPOO & $0,338 \pm 0,368$ & $-0,018 \pm 0,424$ & $0,585 \pm 0,620$ \\
\hline
\end{tabular}

Analisando esses dados, foi verificado que, sob as condições do estudo, não tiveram mudanças significativas de cor entre as mechas submetidas a diferentes tratamentos, após 144 horas de radiação em simulador solar. Entretanto, é esperado que a avaliação com outras técnicas mais adequadas, como a espectrofotometria de reflectância difusa, forneceria melhores valores, com diminuição do erro e maior sensibilidade.

\subsubsection{Microscopia Eletrônica de Varredura}

No presente estudo, as mechas de cabelo foram expostas ao dano da radiação ultravioleta, infravermelha e visível em um simulador solar. Dessa forma, as mechas de cabelo foram expostas à radiação em uma configuração que simula a luz solar do meio dia em incidência normal no solstício de verão, durante o período de 144h. Em outras palavras, as mechas foram submetidas a danos que refletem o que ocorreria após um longo período de exposição solar natural.

A superfície cuticular de um cabelo virgem em boas condições é hidrofóbica (KAMATH; DANZIGER; WEIGMANN, 1984; WOLFRAM; LINDERMANN, 1971) em grande extensão, resultando da camada de ácidos graxos covalentemente ligada à camada mais superficial da cutícula, a epicutícula (NEGRI; CORNELL; RIVETT, 1993; SHAO; JONES; MITCHELL, 1997; TANAMACHI et al., 2010). As imagens obtidas por meio da microscopia eletrônica de varredura (MEV) para um cabelo saudável e virgem, confirmam o descrito em literatura, com células sobrepostas e camada uniforme, conforme verificado na Figura 19. 
Figura 19 - Micrografia Eletrônica de Varredura do fio de cabelo virgem, castanho escuro e extra curly, em um aumento de 1.000 vezes (A) e 5.000 vezes (B), com detalhes da cutícula com camadas sobrepostas em um cabelo saudável.

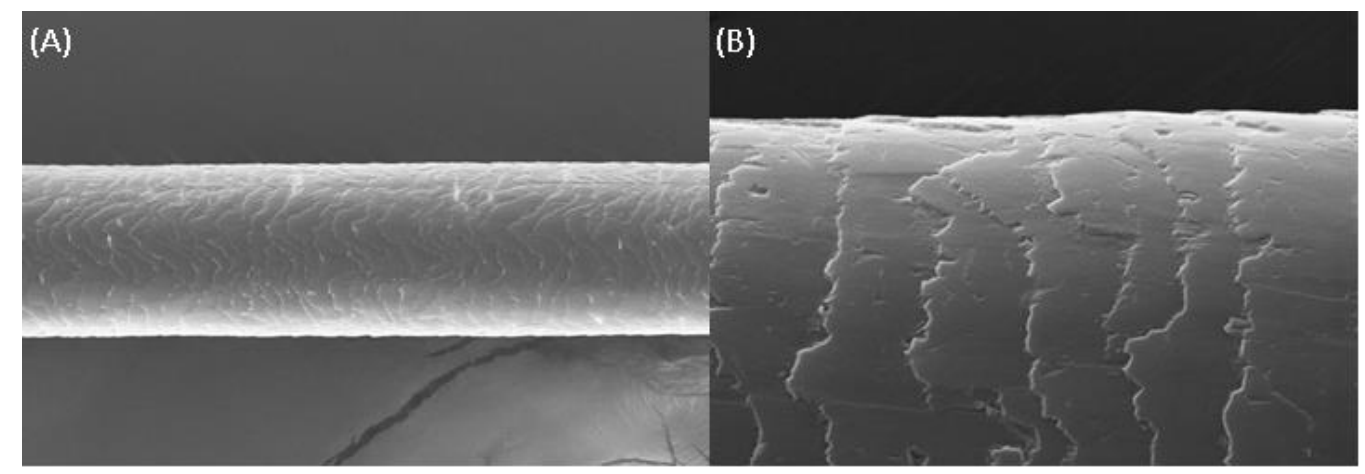

Nas imagens do cabelo irradiado sem nenhum tratamento cosmético, é nítida a degradação da camada cuticular (Figura 20). Nessas imagens, é possível visualizar regiões de exposição do córtex, com células cuticulares fragmentadas ou totalmente removidas. Comparativamente às demais imagens, foi a condição que gerou maior dano a cutícula, com grandes regiões com ausência de células cuticulares e, consequentemente, exposição do córtex ou de camadas da cutícula mais internas, como a endocutícula. Essa perda total ou parcial de camadas da cutícula, levam a alteração das características superficiais do fio, com destaque para a perda de sua característica predominantemente hidrofóbica, além da diminuição do brilho e sedosidade.

Figura 20 - Micrografia Eletrônica de Varredura do fio de cabelo, castanho escuro e extra curly, após exposição a um simulador solar por $144 \mathrm{~h}$. Aumento de 1.000 vezes (A) e 5.000 vezes (B, C e D), com detalhes da cutícula com células fragmentadas e exposição do córtex.

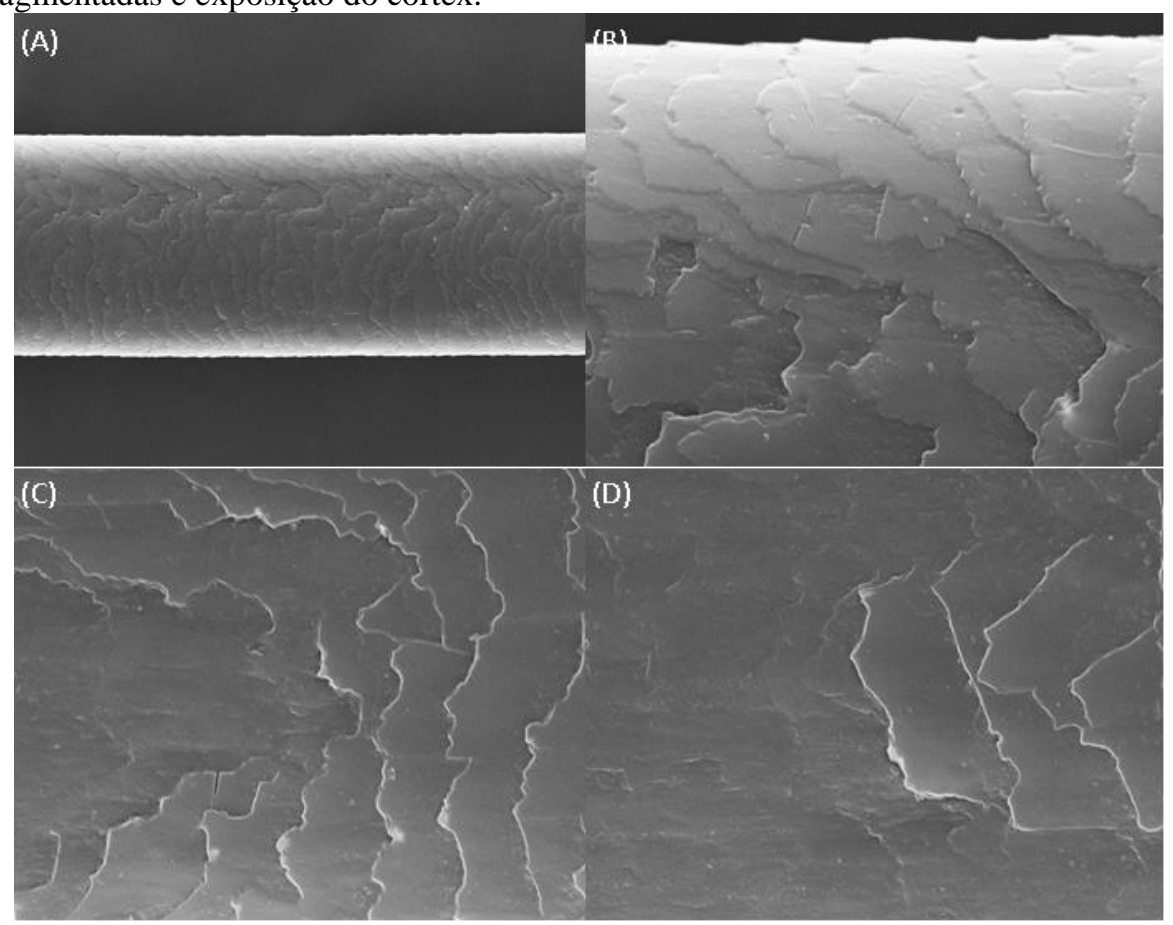


É conhecido que a principal função dos condicionadores é proteger os elementos estruturais do cabelo, especialmente a cutícula, dos efeitos dos cuidados diários e danos ambientais e químicos. Todos esses fatores levam a fragmentação, quebra e perda de células cuticulares (GARCIA; EPPS; YARE, 1978; KELLY; ROBINSON, 1982; TATE; KAMATH; RUETSCH, 1993).

Alguns experimentos com mechas de cabelo submetidas ao ato de pentear de maneira repetida (700 repetições), na presença ou não de agentes condicionadores, demonstrou a importância que essas formulações cosméticas tiveram na manutenção da integridade capilar (REICH et al., 2009). Também no presente estudo, as imagens obtidas pela microscopia eletrônica de varredura possibilitam claramente observar o comprometimento das células cuticulares dos fios analisados, após serem submetidas ao dano que, no caso em questão, foi a radiação solar.

Em relação às imagens obtidas para as mechas que passaram pela etapa de pré-tratamento com formulações cosméticas, observou-se que houve uma proteção do fio analisado. Isso foi verificado com o emprego do veículo, bem como, quando foram adicionados os óleos vegetais e o filtro solar (Figuras 21, 22 e 23, respectivamente). As imagens obtidas para as mechas que passaram pelo tratamento cosmético são semelhantes às obtidas para o cabelo virgem (Figura 19).

Figura 21 - Micrografia Eletrônica de Varredura do fio de cabelo, castanho escuro e extra curly, submetido ao pré-tratamento com formulação veículo em um aumento de 1.000 vezes (A) e 5.000 vezes (B), com detalhes da cutícula preservada, com células sobrepostas.

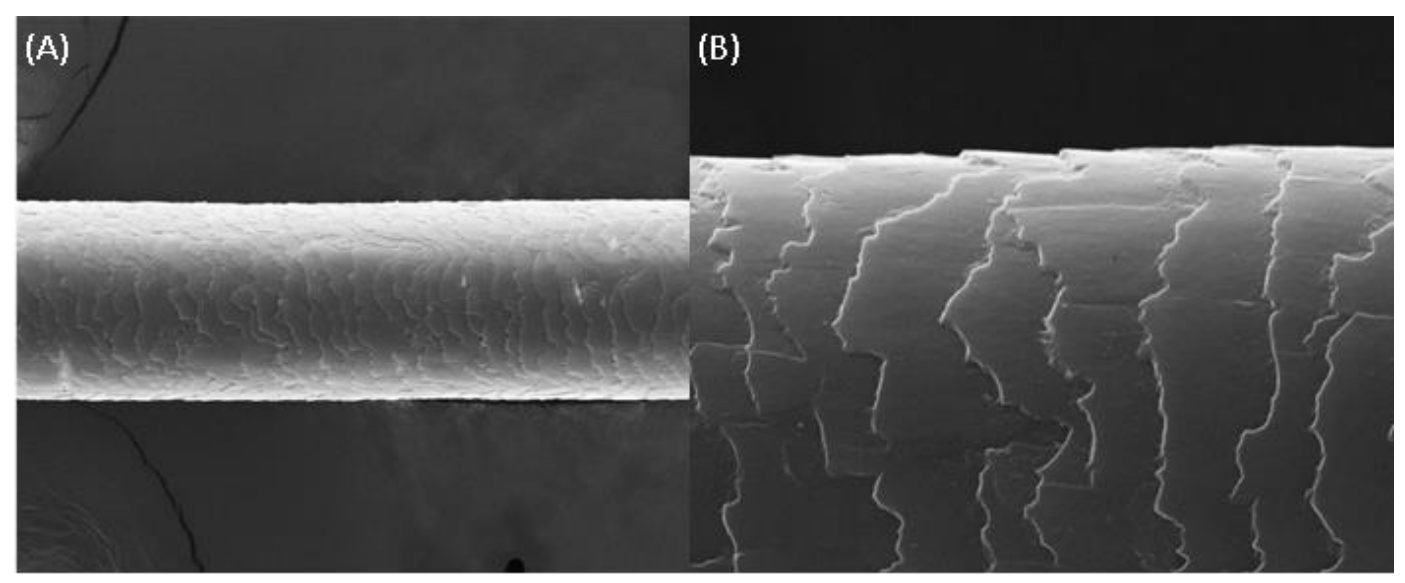


Figura 22 - Micrografia Eletrônica de Varredura do fio de cabelo, castanho escuro e extra curly, submetido ao pré-tratamento com formulação veículo adicionada de filtro solar em um aumento de 1.000 vezes (A) e 5.000 vezes (B), com detalhes da cutícula preservada, com células sobrepostas.

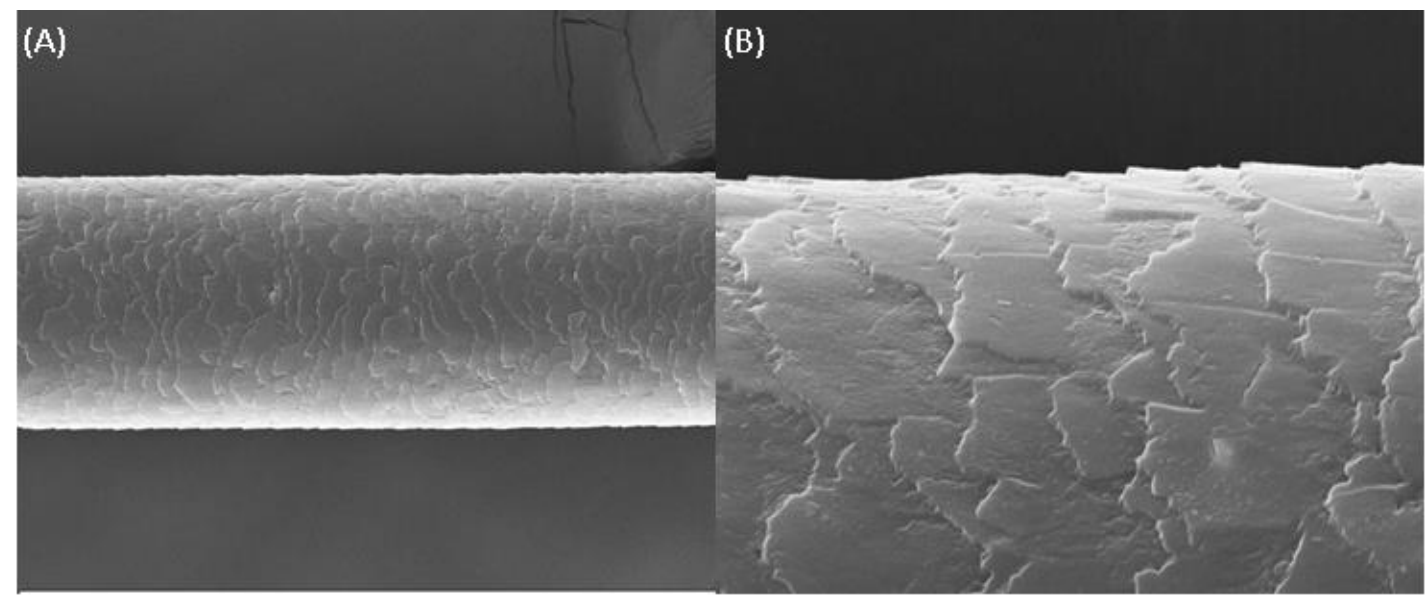

Figura 23 - Micrografia Eletrônica de Varredura do fio de cabelo, castanho escuro e extra curly, submetido ao pré-tratamento com formulação veículo adicionada dos óleos vegetais em um aumento de 1.000 vezes (A) e 5.000 vezes (B), com detalhes da cutícula preservada, com células sobrepostas.

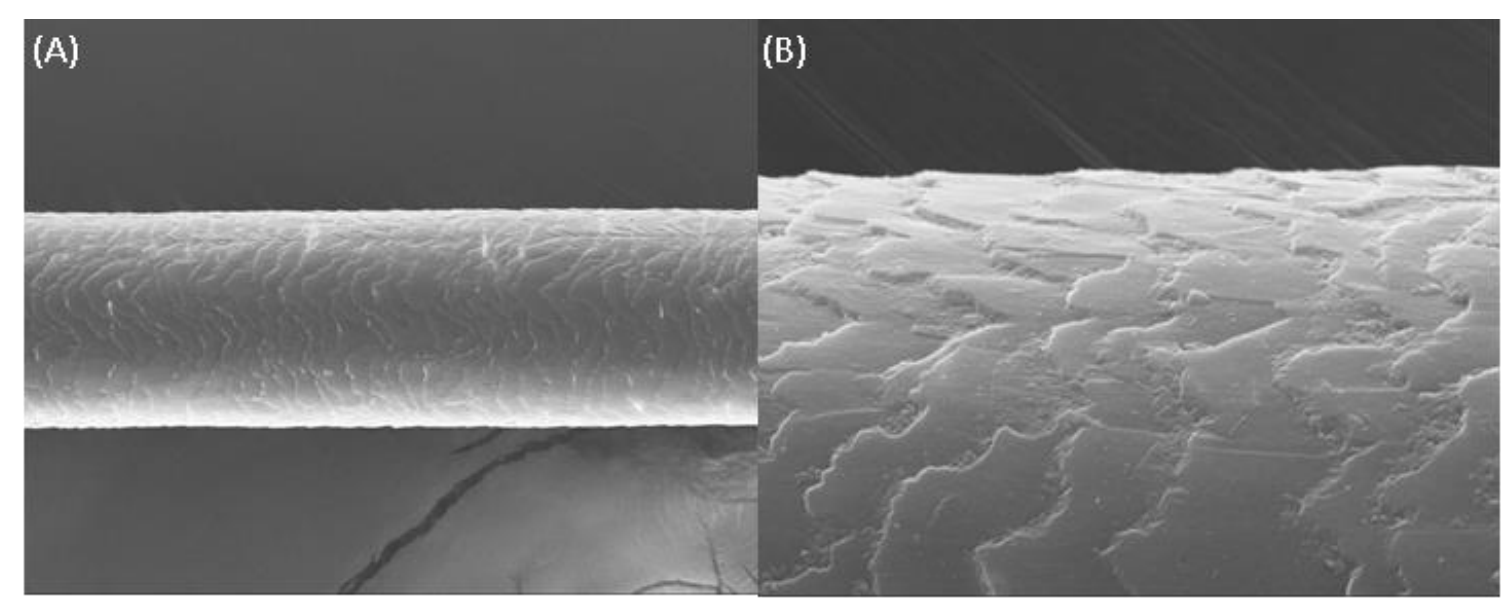

Confirmando o efeito protetor observado, também nas imagens obtidas com as mechas que passaram pelo tratamento com a formulação completa, contendo os óleos vegetais e o filtro solar (Figura 24), a cutícula apresenta-se mais uniforme, preservada e em melhores condições quando comparada ao cabelo irradiado (Figura 20). Esse efeito pode ser atribuído aos agentes condicionadores presentes em todas as formulações, tais como tensoativos catiônicos, silicone e álcoois graxos, que atuam formando um filme de revestimento superficial, que mantém as células cuticulares mais unidas e sobrepostas. Além disso, atribuem-se aos ingredientes cosméticos com cargas positivas a capacidade de neutralizar as cargas negativas inerentes à superfície capilar e que estão aumentadas após a exposição à 
radiação ultravioleta devido a oxidação da cistina em ácido cisteico (HUNTING, 1987; JACHOWICZ; WIS-SUREL; GARCIA, 1985; QUACK, 1976; ROBBINS, 2012).

Figura 24 - Micrografia Eletrônica de Varredura do fio de cabelo, castanho escuro e extra curly, submetido ao pré-tratamento com formulação veículo adicionada de filtro solar e óleos vegetais em um aumento de 1.000 vezes (A) e 5.000 vezes (B), com detalhes da cutícula preservada, com células sobrepostas.

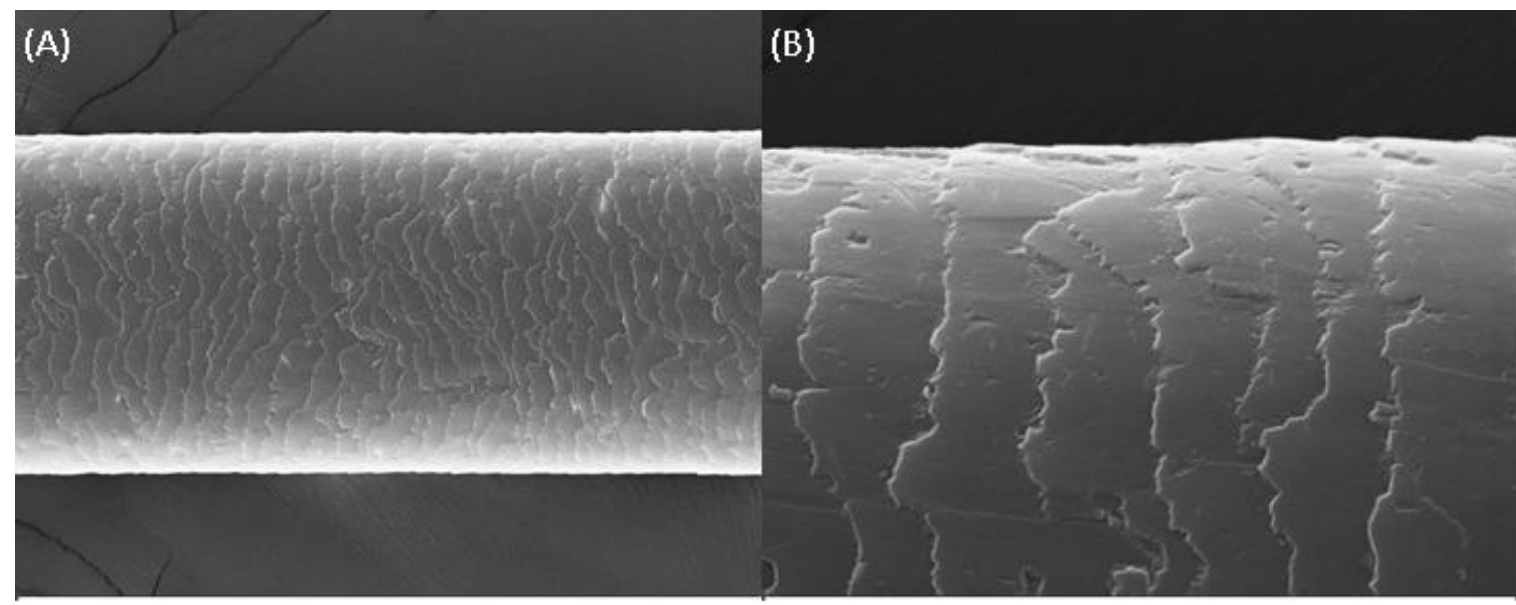

A manutenção das características da cutícula possui grande importância, uma vez que são facilmente perceptíveis para as pessoas, por influenciarem diretamente na sensação ao toque e brilho superficial (REICH et al., 2009). Isso confirma a principal função dos agentes condicionadores de proteger os elementos constituintes do cabelo, especialmente a cutícula, dos danos ambientais e dos causados pelos cuidados diários (KELLY; ROBINSON, 1982; REICH et al., 2009; TATE; KAMATH; RUETSCH, 1993).

Em relação à etapa de pós-tratamento, verifica-se na Figura 25 que a utilização do veículo da formulação pós-tratamento não foi capaz de reparar os danos causados pela exposição dos cabelos ao simulador solar. Apesar disso, pela imagem obtida, a extenção do dano parece ser menor quando comparada a imagem do cabelo irradiado sem nenhum tratamento cosmético (Figura 20). Isso pode indicar que, embora as formulações não sejam capazes de restaurar as células cuticulares perdidas, os componentes da formulações atuaram melhorando as condições das células que se mantiveram, mesmo após a indução do dano. 
Figura 25- Micrografia Eletrônica de Varredura do fio de cabelo, castanho escuro e extra curly, submetido ao pós-tratamento com formulação veículo em um aumento de 1.000 vezes (A) e 5.000 vezes (B), com detalhes da cutícula com regiões danificadas, com células fragmentadas e exposição do córtex.

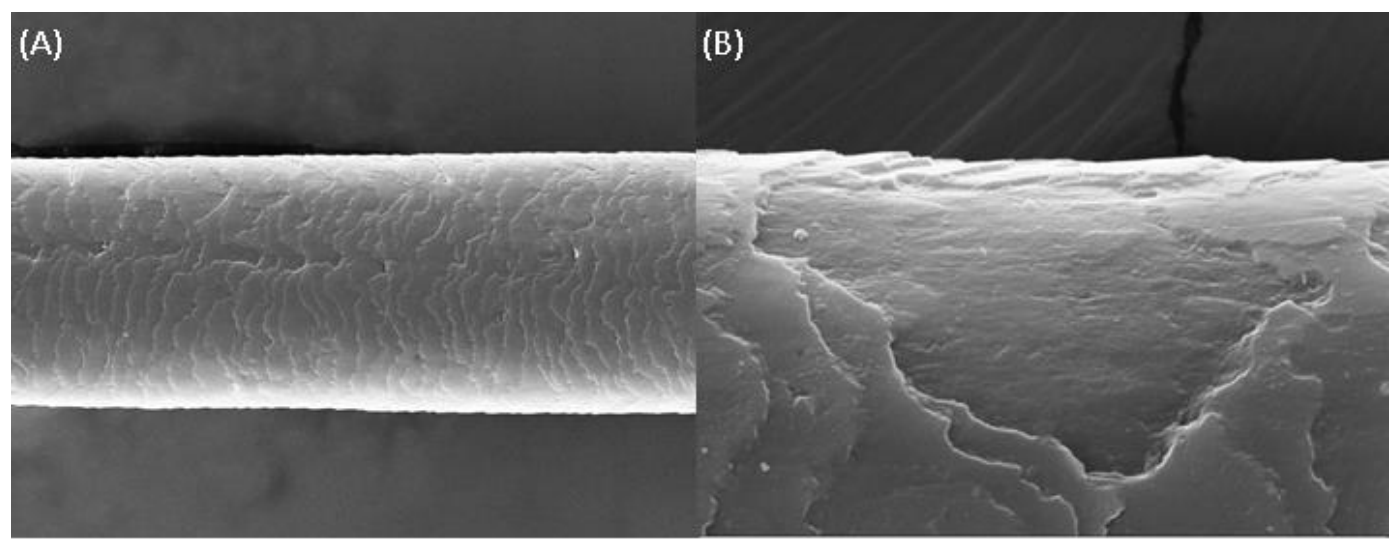

Na Figura 26, a imagem obtida com a utilização da formulação de pós-tratamento com adição dos óleos vegetais demonstrou uma camada superficial do fio íntegra, semelhante ao observado para todas as formulações pré-tratamento e para o cabelo virgem. Embora possa parecer que houve uma recuperação da superfície capilar, não é a hipótese mais provável. Sendo o fio de cabelo uma estrutura morta, a recuperação de células cuticulares perdidas não é possível e o que se esperava com o tratamento era uma mehora da superfície dos cabelos, com preservação das células cuticulares existentes. Esse resultado foi alcançado, uma vez que nota-se a superfície do cabelo bem preservada. Em outras palavras, ao contrário das imagens obtidas para o veículo de pós-tratamento e do cabelo irradiado sem a presença de nenhum tratamento cosmético, na imagem da Figura 26 não apareceram partes de remoção total das células cuticulares, mas provavelmente essas regiões estão presentes em outras áreas ou fios de cabelo. Apesar disso, nas camadas onde as células cuticulares foram preservadas, elas estão em bom estado, indicando a possível ação da formulação cosmética de pós-tratamento contendo os óleos vegetais na preservação e melhora das condições do fio. 
Figura 26 - Micrografia Eletrônica de Varredura do fio, castanho escuro e extra curly, de cabelo submetido ao pós-tratamento com formulação veículo adicionada dos óleos vegetais em um aumento de 1.000 vezes (A) e 5.000 vezes (B), com detalhes da cutícula preservada, com células sobrepostas.

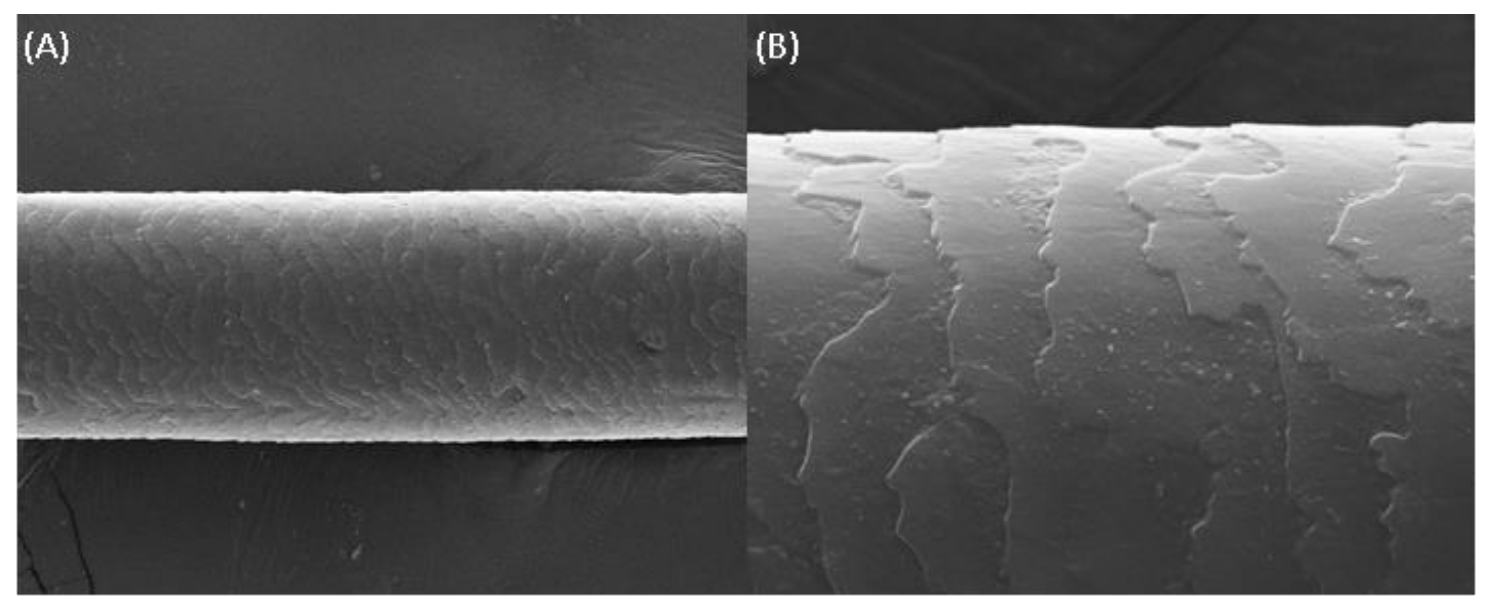

Cabe ressaltar que as imagens obtidas pela microscopia eletrônica de varredura são feitas a partir da observação de um fio de cabelo único, representativo da mecha em análise. Dessa forma, a afirmação da eficácia das formulações desenvolvidas em proteger ou reparar os cabelos submetidos ao dano pela exposição solar não deve ser feita com essa análise isoladamente.

Apesar disso, a observação da preservação da camada superficial dos fios analisados, quando foram utilizadas as formulações cosméticas desenvolvidas, foi verificada de maneira geral. Entretanto, diferenças de eficácia entre as formulações, contendo filtro solar ou óleos vegetais isoladamente, não foram nítidas e, portanto, não são conclusivas. Por tudo isso, o efeito geral dos componentes das formulações, representados por diferentes substâncias condicionadoras, parece ter tido maior influência que o uso do filtro solar adicionado nesse estudo.

Considerando que a endocutícula e o complexo da membrana celular são as camadas da cutícula com menor densidade de ligações cruzadas, elas estão mais vulneráveis aos danos causados pelo intumescimento da fibra. Esse intumescimento leva ao levantamento da superfície cuticular, que se curva, tornando-se mais susceptível a quebra . A utilização de óleos vegetais possui um importante papel nesse contexto, visto que é capaz de formar uma camada protetora e lubrificante na fibra, além de penetrá-la, de forma a diminuir o intumescimento e, portanto, preservar as células cuticulares. Apesar disso, outros constituintes da formulação desenvolvida nesse estudo, também possuem essa capacidade de revestimento, podendo ter, portanto, atuado por esse mecanismo, preservando, assim, a camada superficial da fibra mesmo quando somente o veículo foi empregado. 


\subsubsection{Degradação do Triptofano}

O processo de fotodegradação ocorre nas proteínas do cabelo, principalmente na região da cutícula, que está exposta a uma maior quantidade de radiação. Conforme descrito anteriormente, o aminoácido triptofano é apontado como um indicador de dano causado pela radiação no cabelo humano (PANDE; JACHOWICZ, 1993). Ele é parte da queratina e absorve radiação UV em um comprimento de onda máximo de $280 \mathrm{~nm}$.

Nesse estudo, foram obtidas as intensidades de fluorescência das mechas de cabelo virgem (CV), com média de intensidade em torno de 13,08 u.a.. O cabelo irradiado sem nenhum tratamento cosmético foi o que a apresentou a maior perda de intensidade de fluorescência, cerca de 58\% de redução. Em um estudo conduzido com mechas de cabelos exposta a radiação solar por $150 \mathrm{~h}$, foi observada redução de $25-30 \%$ da concentração de triptofano (DRAELOS, 2014). Os valores da perda de intensidade da fluorescência encontrada neste estudo foram maiores. Entretanto, sabe-se que existem diversas limitações da técnica, uma vez que a cinética de degradação do triptofano é complexa e pode ser afetada por vários fatores. Dentre esse fatores, destaca-se a exposição não uniforme da fibra capilar dentro da câmara do simulador solar, podendo levar a danos mais evidentes na camada superficial do que no interior da fibra, além do fato do cabelo ser um material orgânico, o que faz com que haja uma grande variabilidade nas medidas em diferentes grupos de mechas (LONGO et al., 2013). Apesar desses fatores limitantes, a fluorescência é uma técnica importante para a caracterização de fibras capilares após a exposição a grande quantidade de radiação, sendo portanto suficientemente precisa para propostas qualitativas ou comparativas (LONGO et al., 2013), como é o objetivo da avaliação realizada nesse estudo.

Posto isso, observou-se que os outros tratamentos levaram a reduções semelhantes às observadas no cabelo irradiado sem nenhum tratamento cosmético, com exceção das formulações que foram adicionados de filtro solar. Assim, as formulações VPEF e VPEOF, que representam os veículos de pré-tratamento adicionadas do filtro solar e do filtro solar e óleos vegetais, respectivamente, foram capazes de proteger a fibra. Essa proteção é indicada pela menor degradação do triptofano, cerca de $27 \%$ de diminuição em relação ao valor encontrado para o cabelo virgem para VPEOF e 33\% para VPEF. Isso se deve provavelmente ao fato de que, com a utilização do filtro solar, uma menor quantidade de radiação ultravioleta chegou ao fio de cabelo, diminuindo os danos consequentes desse processo. Somente os veículos e as formulações contendo os óleos vegetais não foram suficientes para diminuir a degradação do triptofano, indicando que, para essa análise, o emprego do filtro solar foi 
importante para o resultado de proteção. Além disso, fica claro que, uma vez que ocorreu o dano, as formulações de pós-tratamento não foram capazes de restaurar a fibra, considerando que os resultados obtidos nessa etapa foram semelhantes ao obtido para o cabelo irradiado sem nenhum tratamento cosmético. Na Figura 27 está descrita a média dos valores de fluorescência obtidos para as mechas de cabelo submetidas aos diferentes tratamentos.

Outros estudos também avaliaram a decomposição do triptofano como indicador de dano pela radiação ultravioleta e também relataram valores diferentes de fluorescência para cabelos submetidos a diferentes tratamentos (FERNÁNDEZ et al., 2012a, 2012b; SANTOS NOGUEIRA; JOEKES, 2004).

FIgura 27 - Intensidade de Fluorescência (u.a.) obtidos para as mechas de cabelo submetidas a diferentes tratamentos com formulações cosméticas, antes ou após exposição no Simulador Solar, e seus respectivos controles (Cabelo virgem e cabelo irradiado sem nenhum tratamento cosmético).

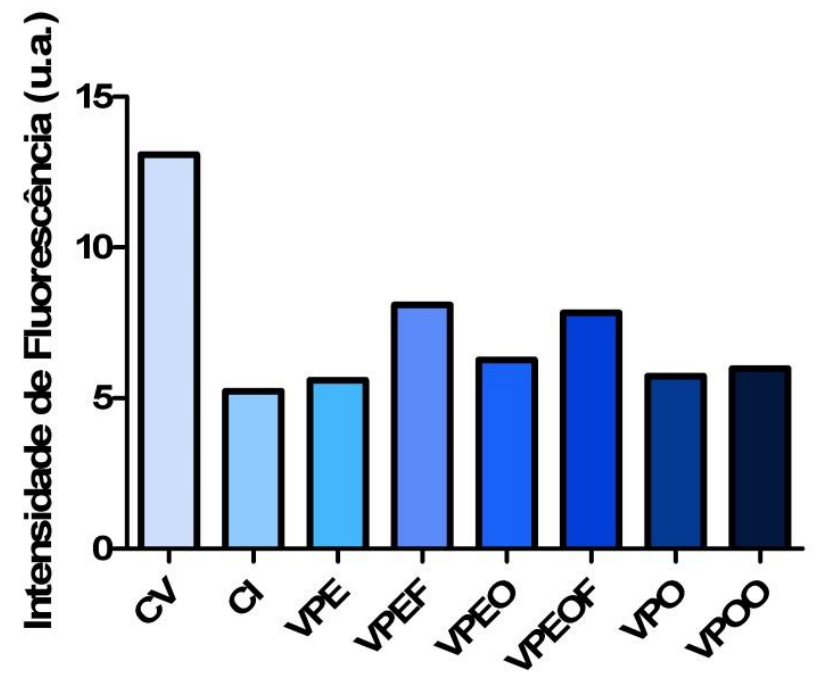

Legenda: CV: mechas de cabelo virgem; CI: mechas irradiadas no simulador solar sem nenhum tratamento cosmético; VPE: mechas tratadadas com veículo de pré-tratamento; VPEF: mechas tratadas com veículo de prétratamento adicionado de filtro solar; VPEO: mechas tratadas com veículo de pré-tratamento adicionado dos óleos vegetais; VPEOF: mechas tratadas com veículo de pré-tratamento adicionado dos óleos vegetais e filtro solar; VPO: mechas tratadadas com veículo de pós-tratamento e VPOO: mechas tratadas com veículo de póstratamento adicionado dos óleos vegetais. 
6. Conclusão 
Nas condições experimentais deste estudo foi possível concluir que:

As formulações na forma de cremes de pré-tratamento e pós-tratamento com enxágue (rinse off), contendo óleos vegetais, propostas no protocolo de Pesquisa \& Desenvolvimento foram adequadas às finalidades propostas e selecionadas com base na análise sensorial e na avaliação da resistência mecânica dos fios, quando aplicadas em mechas submetidas ao alisamento químico.

A reologia foi uma ferramenta importante no estudo, uma vez que possibilitou a escolha da melhor proporção entre a base autoemulsionante e o agente de consistência, de forma a orientar a escolha da formulação mais estável.

A aplicação da formulações contendo os óleos vegetais e o filtro solar, isolados ou associados, nas mechas submetidas à radiação solar, manteve a resistência mecânica das fibras capilares semelhante à obtida para as mechas virgem. Isso indica um efieto benéfico do emprego dos óleos vegetais e do filtro solar nas propriedades mecânicas do fio, uma vez que os veículos não resultaram na proteção da fibra capilar.

Além disso, as imagens do Microscópio Eletrônico de Varredura demonstraram a maior preservação da cutícula das mechas tratadas com as todas formulações desenvolvidas, quando comparadas às mechas que não receberam nenhum tratamento cosmético, com melhores resultados observados na etapa de pré-tratamento.

Ainda, a análise da intensidade de fluorescência para verificação da degradação do triptofano confirmou uma menor extensão do dano nos cabelos tratados com as formulações contendo o filtro solar.

Concluindo, as formulações desenvolvidas tiveram importante efeito na proteção e reparação dos danos da fibra, o qual foi demonstrado tanto pela percepção dos usuários potenciais dos cosméticos desenvolvidos, por meio da análise sensorial, quanto pelos resultados das diferentes análises objetivas realizadas no estudo. 


\section{Referências Bibliográficas}


ABDULKARIM, S. M. et al. Frying quality and stability of high-oleic Moringa oleifera seed oil in comparison with other vegetable oils. Food Chemistry, v. 105, n. 4, p. 1382-1389, jan. 2007.

ABIHPEC. Associação Brasileira das Indústrias de Higiene Pessoal e Cosméticos. Panorama do Mercado Brasileiro. Disponível em:

$<$ http://www.abihpec.org.br/en/category/publicacoes/panorama-do-setor/>. Acesso em: 7 mar. 2015.

ABURJAI, T.; NATSHEH, F. M. Plants used in Cosmetics. Phytotherapy research : PTR, v. 17 , n. 9 , p. $987-1000$, nov. 2003.

ANWAR, F. et al. Enhancement of the oxidative stability of some vegetable oils by blending with Moringa oleifera oil. Food Chemistry, v. 103, n. 4, p. 1181-1191, jan. 2007.

ANWAR, F.; BHANGER, M. I. Analytical characterization of Moringa oleifera seed oil grown in temperate regions of Pakistan. Journal of agricultural and food chemistry, v. 51, n. 22 , p. $6558-6563,22$ out. 2003.

BERASATEGI, I. et al. Stability of avocado oil during heating: Comparative study to olive oil. Food Chemistry, v. 132, n. 1, p. 439-446, maio 2012.

BERGER, A.; JONES, P. J. H.; ABUMWEIS, S. S. Plant sterols : factors affecting their efficacy and safety as functional food ingredients. Lipids in health and disease, v. 3, p. 119, 2004.

BHUSHAN, B. Nanoscale characterization of human hair and hair conditioners. Progress in Materials Science, v. 53, n. 4, p. 585-710, maio 2008.

BOLDUC, C.; SHAPIRO, J. Hair care products: waving, straightening, conditioning, and coloring. Clinics in Dermatology, v. 19, n. 4, p. 431-436, jul. 2001.

BRASIL. Agência Nacional de Vigilância Sanitária - ANVISA. Disponível em: <www.anvisa.gov.br>. Acesso em: 20 mar. 2014.

CHANDRASHEKARA, M. N.; RANGANATHAIAH, C. Chemical and photochemical degradation of human hair: a free-volume microprobe study. Journal of photochemistry and photobiology. B, Biology, v. 101, n. 3, p. 286-294, 2 dez. 2010.

CHARROUF, Z.; GUILLAUME, D. Ethnoeconomical, ethnomedical, and phytochemical study of Argania spinosa (L.) Skeels. Journal of ethnopharmacology, v. 67, n. 1, p. 7-14, out. 1999.

CHARROUF, Z.; GUILLAUME, D. Argan oil: Occurrence, composition and impact on human health. European Journal of Lipid Science and Technology, v. 110, n. 7, p. 632636, jul. 2008.

CHE MAN, Y. B. et al. Quality changes of refined-bleached-decolorized (RBD) palm olein, soybean oil and their blends during deep-fat frying. Journal of Food Lipids, v. 6, p. 181193, 1999. 
CHOE, E.; MIN, D. B. Chemistry of deep-fat frying oils. Journal of food science, v. 72, n. 5, p. R77-86, jun. 2007.

CHOU, C.-C.; BUEHLER, M. J. Structure and mechanical properties of human trichocyte keratin intermediate filament protein. Biomacromolecules, v. 13, n. 11, p. 3522-3532, 12 nov. 2012.

DIAS, T. C. DE S. et al. Relaxing/straightening of Afro-ethnic hair: historical overview. Journal of cosmetic dermatology, v. 6, n. 1, p. 2-5, mar. 2007.

DIAS, T. C. DE S. et al. Protective effect of conditioning agents on Afro-ethnic hair chemically treated with thioglycolate-based straightening emulsion. Journal of cosmetic dermatology, v. 7, n. 2, p. 120-126, jun. 2008.

DRAELOS, Z. D. Shampoos, conditioners, and camouflage techniques. Dermatologic clinics, v. 31, n. 1, p. 173-178, jan. 2013.

DRAELOS, Z. D. Hair, sun, regulation, and beauty. Journal of cosmetic dermatology, v. 13, n. 1, p. 1-2, mar. 2014.

DUBIEF, C. Experiments in hair degradation. Cosmetic \& Toiletries, v. 107, p. 95-102, 1992.

DWECK, A. C. African Plants. Cosmetic \& Toiletries, v. 112, p. 41-51, 1997.

ERIK, B. et al. Biomechanical properties of human hair with different parameters. Skin research and technology, v. 14, n. 2, p. 147-151, maio 2008.

FARIA, P. M. et al. Hair Protective Effect of Argan Oil ( Argania spinosa Kernel Oil ) and Cupuassu Butter ( Theobroma grandiflorum Seed Butter ) Post Treatment with Hair Dye. $n$. September, p. 40-44, 2013.

FERNÁNDEZ, E. et al. Photodamage determination of human hair. Journal of photochemistry and photobiology. B, Biology, v. 106, n. 1, p. 101-106, 5 jan. 2012a.

FERNÁNDEZ, E. et al. Efficacy of antioxidants in human hair. Journal of photochemistry and photobiology. B, Biology, v. 117, p. 146-156, 5 dez. 2012 b.

FOERSTER, T.; SCHWUGER, M. G. Correlation between adsorption and of the surfactants and polymers on hair. Progress in Colloid and Polymers Science, v. 83, p. 104-109, 1990.

FREGONESI, A. et al. Brazilian oils and butters: The effect of different fatty acid chain composition on human hair physiochemical properties. Journal of Cosmetic Science, v. 60, n. 2, p. 273-280, 2009.

FUKUHARA, M.; NOJIRI, M. Multi-component hair dye compositionJapão, 2011.

GARCIA, M. L.; EPPS, J. A.; YARE, R. S. Normal cuticle-wear pattern in human hair. Journal of the Society of Cosmetic Chemists, v. 29, p. 155-175, 1978. 
GERRARD, W. The measurement of hair colour. International journal of cosmetic science, v. 11, p. 97-101, 1989.

GUILlAUME, D.; CHARROUF, Z. Argan oil. Alternative Medicine Review, v. 16, n. 3, p. 275-279, 2011a.

GUILLAUME, D.; CHARROUF, Z. Argan oil and other argan products: Use in dermocosmetology. European Journal of Lipid Science and Technology, v. 113, n. 4, p. 403-408, 11 abr. 2011b.

GUNSTONE, F. D. VEGETABLE OILS IN FOOD TECHNOLOGY: Composition, Properties and Uses. 1. ed. England: Blackwell Publishing, 2002. p. 1-352

HABE, T. et al. ToF-SIMS characterization of the lipid layer on the hair surface. I: the damage caused by chemical treatments and UV radiation. Surface and Interface Analysis, v. 43, n. 1-2, p. 410-412, 11 jan. 2011.

HARHAR, H.; GHARBY, S.; KARTAH, B. E. Long argan fruit drying time is detrimental for argan oil quality. Natural Products Communication, v. 5, p. 1799-1802, 2010.

HERRLING, T.; JUNG, K.; FUCHS, J. The role of melanin as protector against free radicals in skin and its role as free radical indicator in hair. Spectrochimica acta. Part A, Molecular and biomolecular spectroscopy, v. 69, n. 5, p. 1429-35, maio 2008.

HORIRICHI, T. Nature of damaged hair. v. 93, p. 65-77, 1978.

HUNTING, A. L. L. Encyclopedia of conditioning rinse ingredients. New Jersey: Micelle Press, 1987.

IBRAHIM, S. S. et al. Benseed: a potential oil source. Agric. Res. Rev., v. 52, p. 47-50, 1974.

JACHOWICZ, J. Evaluating Effects of Condiotining Formulations on Hair. In:

SCHUElLER, R.; ROMANOWSKI, P. (Eds.). Conditioning Agents for Hair and Skin. 1. ed. New York: Marcel Dekker, 1999.

JACHOWICZ, J.; WIS-SUREL, G.; GARCIA, M. L. Relationship between triboelectric charging and surface modifications of human hair. Journal of the Society of Cosmetic Chemists, v. 36, p. 189-212, 1985.

JIANG, Q. et al. gamma -Tocopherol, the major form of vitamin E in the US diet, deserves more attention. American Journal of Clinical Nutrition, v. 74, p. 714-722, 2001.

KAMATH, Y. K.; DANZIGER, C. J.; WEIGMANN, H.-D. Surface wettability of humam hair.I Effect of deposition of polymers and surfactant. Journal of Applied Polymer Science, v. 29, p. 1011-1026, 1984.

KAMEYAMA, S. Application and consideration of medicinal plants for hair care products. Frag J, v. 23, p. 28-34, 1995. 
KAPLIN, I. J.; SCHWANN, A.; ZAHN, H. Effects of cosmetic treatments on the ultrastructure of hair. Cosmetic \& Toiletries, v. 97, p. 22-26, 1982.

KEIS, K. et al. Investigation of penetration abilities of various oils into human hair fibers. Journal of Cosmetic Science, v. 56, n. 5, p. 283-295, 2005.

KEIS, K.; HUEMMER, C. L.; KAMATH, Y. K. Effect of oil films on moisture vapor absorption on human hair. Journal of cosmetic science, v. 58, n. 2, p. 135-145, 2007.

KELLY, S. E.; ROBINSON, V. N. E. The effect of grooming on the hair cuticle. Journal of the society of Cosmetic Chemists, v. 33, n. July, p. 203-215, 1982.

KHUMALO, N. P. et al. "Relaxers" damage hair: evidence from amino acid analysis. Journal of the American Academy of Dermatology, v. 62, n. 3, p. 402-408, mar. 2010.

KLEIMAN, R.; ASHLEY, D. A.; BROWN, J. H. Comparison of two seed oils used in cosmetics, moringa and marula. Industrial Crops and Products, v. 28, n. 3, p. 361-364, nov. 2008.

KUZUHARA, A. Chemical modification of keratin fibers using 2-iminothiorane hydrochloride. Journal of Applied Polymer Science, v. 90, n. 13, p. 3646-3651, 20 dez. 2003.

KUZUHARA, A. Analysis of structural change in keratin fibers resulting from chemical treatments using Raman spectroscopy. Biopolymers, v. 77, n. 6, p. 335-344, 15 abr. 2005.

LEE, W.-S. Integral hair lipid in human hair follicle. Journal of dermatological science, v. 64, n. 3, p. 153-158, dez. 2011.

LONGO, V. M. et al. Towards an insight on photodamage in hair fibre by UV-light: An experimental and theoretical study. International journal of cosmetic science, v. 35, n. 6 , p. 539-545, dez. 2013.

MARIOD, A.; EICHNER, K.; HUSSEIN, I. H. IMPROVING THE OXIDATIVE STABILITY OF SUNFLOWER OIL BY BLENDING WITH SCLEROCARYA BIRREA AND ASPONGOPUS VIDUATUS OILS. Journal of Food Lipids, v. 12, p. 150-158, 2005.

MIRANDA-VILELA, A. L.; BOTELHO, A. J.; MUEHLMANN, L. A. An overview of chemical straightening of human hair: technical aspects, potential risks to hair fibre and health and legal issues. International journal of cosmetic science, 19 set. 2014.

MORAIS, G. G.; OLIVEIRA, W. P.; ROCHA-FILHO, P. A. Influence of Mixing Speed in Liquid Crystal Formation and Rheology of O / W Emulsions Containing Vegetable Oils. Journal of dispersion science and technology, v. 35, p. 1551-1556, 2014.

MOSER, P.; CORNELIO, M. L.; NICOLETTI TELIS, V. R. Influence of the concentration of polyols on the rheological and spectral characteristics of guar gum. LWT - Food Science and Technology, v. 53, n. 1, p. 29-36, set. 2013. 
NAYSMITH, L. et al. Quantitative Measures of the Effect of the Melanocortin 1 Receptor on Human Pigmentary Status 1. Journal of Investigative Dermatology, v. 122, p. 423-428, 2004.

NEGRI, A. P.; CORNELL, H. J.; RIVETT, D. E. A model for the hair surface of keratin fibers. Textile Research Journal, v. 63, p. 109-115, 1993.

NOGUEIRA, A C. S. et al. Photo yellowing of human hair. Journal of photochemistry and photobiology. B, Biology, v. 88, n. 2-3, p. 119-125, 25 set. 2007.

NOGUEIRA, A. C. S. et al. Hair color changes caused by dyeing and thermal treatments. Journal of cosmetic science, v. 55, n. 5, p. 437-447, 2004.

NOGUEIRA, A. C. S.; DICELIO, L. E.; JOEKES, I. About photo-damage of human hair. Photochemical \& photobiological sciences : Official journal of the European Photochemistry Association and the European Society for Photobiology, v. 5, n. 2, p. 165-169, fev. 2006.

O’LENICK, A. J.; O'LENICK, T. G. Silicone compounds - New formulation possibilities. Cosmetic \& Toiletries, v. 120, n. 3, p. 95-102, 2005.

OKAMOTO, M. et al. Investigation of the damage on the outermost hair surface using ToFSIMS and XPS. Surface and Interface Analysis, v. 44, n. 6, p. 736-739, 2 jun. 2012.

PANDE, C. M.; JACHOWICZ, J. Hair photodamageMeasurement and prevention. Journal of the society of Cosmetic Chemists, v. 44, n. April, p. 109-122, 1993.

PLOWMAN, J. E. et al. Protein oxidation: identification and utilisation of molecular markers to differentiate singlet oxygen and hydroxyl radical-mediated oxidative pathways.

Photochemical \& photobiological sciences, v. 12, n. 11, p. 1960-1967, nov. 2013.

QUACK, J. M. Quaternary ammonium compounds in cosmetics. Cosmetic \& Toiletries, v. 91, n. 2, p. 35-52, 1976.

RAHMANI, M. The chemical composition of virgin argan oil. Agricultures, v. 14, p. 461$465,2005$.

RATNAPANDIAN, S.; WARNER, S. B.; KAMATH, Y. K. Photodegradation of human hair. Journal of cosmetic science, v. 49, p. 309-320, 1998.

REICH, C. et al. Hair Conditioners. In: BAREL, A. O.; PAYE, M.; MAIBACH, H. I. (Eds.). Handbook of Cosmetic Science and Technology. $3^{\circ}$. ed. Nova York: Informa Healthcare USA, Inc., 2009. p. 687-703.

RELE, A. S.; MOHILE, R. B. Effect of coconut oil on prevention of hair damage . Part I. Journal of Cosmetic Science, v. 50, n. December, p. 327-339, 1999.

RELE, A. S.; MOHILE, R. B. Effect of mineral oil, sunflower oil, and coconut oil on prevention of hair damage. Journal of cosmetic science, v. 54, n. 2, p. 175-92, 2003. 
REQUEJO, A. M. et al. Influence of nutrition on cognitive function in a group of elderly, independently living people. European journal of clinical nutrition, v. 57 Suppl 1, p. S5457, set. 2003.

RICHARD BEYAK, M. S.; KASS, B. S.; MEYER, C. F. Elasticity and Tensile Properties. Journal of the society of Cosmetic Chemists, v. 22, p. 667-678, 1971.

RICHENA, M. et al. Yellowing and bleaching of grey hair caused by photo and thermal degradation. Journal of photochemistry and photobiology. B, Biology, v. 138, p. 172-181, set. 2014.

ROBBINS, C. R. Chemical and Physical Behaviour of Human Hair. p. 105-176, 2012.

ROGERS, G. E. Hair follicle differentiation and regulation. The International journal of developmental biology, v. 48, n. 2-3, p. 163-170, jan. 2004.

RUETSCH, S. B.; KAMATH, Y. Photodegradation of human hair : An SEM study. Journal of Cosmetic Science, v. 51, n. April, p. 103-125, 2000.

RUETSCH, S. B.; KAMATH, Y.; WEIGMANN, H. D. Sun Protection in Man. In: Comprehensive Series in Photosciences. Comprehensive Series in Photosciences. [s.1.] Elsevier, 2001. v. 3p. 175-205.

SANDHU, S. S.; RAMACHANDRAN, R.; ROBBINS, C. R. A simple and sensitive method using protein loss measurements to evaluate damage to human hair during combing. Journal of the Society of Cosmetic Chemists, v. 46, p. 39-52, 1995.

SANTOS NOGUEIRA, A. C.; JOEKES, I. Hair color changes and protein damage caused by ultraviolet radiation. Journal of photochemistry and photobiology. B, Biology, v. 74, n. 23, p. 109-117, 27 maio 2004.

SCHWATZ, A.; KNOWLES, D. Frictional effects in human hair. Journal of the Society of Cosmetic Chemists, v. 14, p. 455-463, 1963.

SCOTT, G. V.; ROBBINS, C. R. Effects of surfactants solution on hair fiber friction. Journal of the Society of Cosmetic Chemists, v. 31, p. 179-200, 1980.

SHAO, J.; JONES, D. C.; MITCHELL, R. Time-of-flight-secondary-ion-mass spectrometric (ToF-SIMS) and x-ray photoelectron spectroscopic (XPS) analyses of the surface lipids of wool. Journal of the textile institute, v. 88, p. 317-324, 1997.

SIGNORI, V. Review of the current understanding of the effect of ultraviolet and visible radiation on hair structure and options for photoprotection. Journal of cosmetic science, $v$. 55, n. 1, p. 95-113, 2004.

SOMALI, M. A.; BAJNEDI, M. A.; AL-FHAIMANI, S. S. Chemical composition and characteristcs of Moringa peregrina seeds and seed oil. Journal of the American Oil Chemists' Society, v. 61, n. 1, p. 85-86, 1984. 
SWIFT, J. A. Human hair cuticle: Biologically conspired to the owner's advantage. Journal of Cosmetic Science, v. 50, n. 1, p. 23-47, 1999.

TANAMACHI, H. et al. 18-MEA and hair appearance. Journal of cosmetic science, v. 61, n. 2, p. 147-160, 2010.

TATE, M. L.; KAMATH, Y. K.; RUETSCH, S. B. Quantification and prevention of hair damage. Journal of the Society of Cosmetic Chemists, v. 44, p. 343-371, 1993.

VERMAAK, I. et al. African seed oils of commercial importance - Cosmetic applications. South African Journal of Botany, v. 77, n. 4, p. 920-933, out. 2011.

WEI, G.; BHUSHAN, B.; TORGERSON, P. M. Nanomechanical characterization of human hair using nanoindentation and SEM. Ultramicroscopy, v. 105, n. 1-4, p. 248-266, nov. 2005.

WOLFRAM, L. J. The Reactivity of Human Hair . A Review. In: ORFANOS; MONTAGNA; STUTTGEN (Eds.). Hair Research. New York: Springer-Verlag, 1981. p. 479-500.

WOLFRAM, L. J. Human hair: a unique physicochemical composite. Journal of the American Academy of Dermatology, v. 48, n. 6 Suppl, p. 106-114, jun. 2003.

WOLFRAM, L. J.; LINDERMANN, M. K. O. Some observations on the hair cuticle. Journal of the Society of Cosmetic Chemists, v. 22, p. 839-850, 1971.

WORTMANN, F.-J.; SCHWAN-JONCZYK, A. Investigating hair properties relevant for hair "handle". Part I: hair diameter, bending and frictional properties. International journal of cosmetic science, v. 28, n. 1, p. 61-68, fev. 2006.

ZIMBA, N.; WREN, S.; STUCKI, A. Three major tree nut oils of southern central Africa: Their uses and future as commercial base oils. International Journal of Aromatherapy, v. 15, n. 4, p. 177-182, 2005. 